\title{
Pleistocene Water Crossings and Adaptive Flexibility Within the Homo Genus
}

\author{
Dylan Gaffney ${ }^{1}$
}

Published online: 14 September 2020

(c) The Author(s) 2020

\begin{abstract}
Pleistocene water crossings, long thought to be an innovation of Homo sapiens, may extend beyond our species to encompass Middle and Early Pleistocene Homo. However, it remains unclear how water crossings differed among hominin populations, the extent to which Homo sapiens are uniquely flexible in these adaptive behaviors, and how the tempo and scale of water crossings played out in different regions. I apply the adaptive flexibility hypothesis, derived from cognitive ecology, to model the global data and address these questions. Water-crossing behaviors appear to have emerged among different regional hominin populations in similar ecologies, initially representing nonstrategic range expansion. However, an increasing readiness to form connections with novel environments allowed some $H$. sapiens populations to eventually push water crossings to new extremes, moving out of sight of land, making return crossings to maintain social ties and build viable founder populations, and dramatically shifting subsistence and lithic provisioning strategies to meet the challenges of variable ecological settings.
\end{abstract}

Keywords Pleistocene seafaring · Island colonization · Maritime technology · Migration · Hominin behavior · Adaptive flexibility

\section{Introduction}

Crossing substantial bodies of water-lakes, straits, seas, and oceans-to arrive at new landmasses has previously been seen as a unique innovation within our species, Homo sapiens. These adaptive capacities were thought to be first acquired as

Electronic supplementary material The online version of this article (https://doi.org/10.1007/s1081 4-020-09149-7) contains supplementary material, which is available to authorized users.

Dylan Gaffney

dacg2@cam.ac.uk

1 Department of Archaeology, University of Cambridge, Downing Street, Cambridge CB2 3DZ, UK 
a population of anatomically and behaviorally "modern" $H$. sapiens moved out of Africa and skirted the coast of southern Eurasia before entering Wallacea (Island Southeast Asia) and Sahul (Australia and New Guinea), sometime after 60,000 years ago. Over a quarter century ago, Davidson and Noble (1992) described this maritime colonization as the earliest global evidence for modern human behavior, because the deliberate water crossings through island Wallacea to continental Sahul were associated with systems of symbolic communication and shared meaning (i.e., language) to produce effective seagoing vessels. It also required forward planning and technological provisioning to envisage potential futures, to predict currents and weather conditions, and to arrange regular return trips to recruit new individuals for establishing a viable founder population.

More recently, several crucial (and controversial) sites around the world have sparked debate and have been cited as evidence that the first water crossings were made by earlier hominin lineages, potentially extending the global history of seafaring into the Early and Middle Pleistocene. At the same time, following the discovery of numerous Middle Pleistocene $H$. sapiens sites across eastern Eurasia, unilinear models for the dispersal of coastally adapted Late Pleistocene H. sapiens along the southern coast of Eurasia are now untenable (Dennell and Petraglia 2012; Rabett 2018). Rather, there seems to have been a series of complex dispersal processes and population interactions predating 70,000 years ago (Martinón-Torres et al. 2017). Moreover, the antiquity of pigment use, engraving, and personal decoration, conventionally used to mark the emergence of modern human behavior in $H$. sapiens, has been pushed back in time and attributed to Homo erectus (Joordens et al. 2015), Homo neanderthalensis (Hoffmann et al. 2018), and possibly Homo heidelbergensis (Burdukiewicz 2014). Thus, the concept of "modernity"- - what it is to be a behaviorally modern and distinct species-and how this interrelates to water-crossing behaviors needs to be reexamined.

In this paper, I wade into the debate about Pleistocene water crossings, island colonization, and what this means for understanding behavioral variability within our genus. This builds on pivotal discussions by Keegan and Diamond (1987), Bednarik (2003), Leppard (2015b), and Erlandson (2017), who have investigated the same topic from archaeological and biogeographic perspectives. In particular, I pose three questions: how did water crossings vary across different hominin populations, to what extent did $H$. sapiens uniquely express adaptive flexibility during water crossings and the colonization of novel environments, and how can this help us understand the rate and scale of hominin adaptive flexibility in different regions? The Pleistocene is a useful temporal focus for this discussion, marking the emergence of the Homo genus, and our own species H. sapiens, alongside glacial and interglacial transgressions prior to the establishment of approximately modern sea levels during the Holocene.

The paper first summarizes recent cognitive ecological literature and proposes the concept of adaptive flexibility as a useful work-around to move us past the relatively polarized debate about whether or not different hominin species strategically crossed water gaps. The mechanisms of adaptive flexibility can be tested through two models that describe the rate and scale of behavioral transformations, as set within the framework of established analytical terminology and typology for the study of 
water-crossing behaviors and island colonization processes. Next, paleoenvironmental information highlights the diachronic rates of global changes in sea level, vegetation, and animal resources during the Pleistocene. Global archaeological data are then presented by region to emphasize temporal and spatial variation present within the clade and to tease apart the variable emergence rates for these behaviors in different parts of the world. My primary aim is to use these data to rethink the nature of hominin adaptive flexibility and how it is tethered to local ecologies and long-term behavioral trajectories in different regional populations. In the discussion section, I look into the behavioral overlaps and contrasts between different regional populations, and examine how this played out among $H$. sapiens specifically. I argue that ecological contingencies crafted long-term behavioral trajectories in different regional populations, rather than inherent capacities for water crossings existing only within $H$. sapiens. However, the increasing readiness to form new connections with novel environments seems to have led our species to push water-crossing behaviors, and their adaptive flexibility, into new frontiers.

\section{"Modernity" and Adaptive Flexibility}

Archaeologists usually look for the origins of modern human behavior by identifying evidence for symbolism, technological complexity, abstract thinking, and planning depth (McBrearty and Brooks 2000). There remains intense debate as to whether these behaviors emerged within only our species, or within multiple hominin species (d'Errico 2003; Klein 2008; Mellars 2005). However, recent studies present a substantial record for $H$. neanderthalensis symbolism in the form of pigment use, cave painting, and personal adornment. For instance, on the Iberian Peninsula red pigment hand stencils and rectilinear forms have been directly dated to at least 65,000 years ago, prior to the movement of $H$. sapiens into the area (Hoffmann et al. 2018). There is also some evidence for primordial $H$. erectus symbolism, in the form of engraved shell in Java (Joordens et al. 2015).

Modernity as a single-species behavioral package begins to breakdown further when we turn to eastern Eurasia and the Pacific (Habgood and Franklin 2008), where there is increasing chronological overlap between late surviving or "progressive" $H$. erectus with large cranial capacities, Denisovan hominins, archaic $H$. sapiens or even $H$. heidelbergensis, and early modern $H$. sapiens dating to the Middle-Late Pleistocene (Kaifu 2017). In the east, the primary evidence used to distinguish behavioral modernity among Pleistocene $H$. sapiens has long been the maritime technology required to navigate from Sunda to Sahul.

As such, it is clear that the modernity classification itself is regionally varied and problematic in that it creates a false dichotomy between the "moderns" and the "archaics" (Roberts 2015). Shea (2011) suggests that "behavioral variability" is a preferable, scalar description for the broadening of cognitive horizons, which emerged gradually in the Middle and Late Pleistocene. It is then not necessary for specific populations to fulfill a checklist of modern behaviors because these innovations, such as pigment use, technological provisioning, and maritime technology, 
arose at different times, in different areas, at different scales, and among different morphological species.

Although substantial behavioral variability is evident among Late Pleistocene $H$. sapiens, the same scale of variability was not innate among all hominin populations; rather it emerged over time, following nondirectional behavioral trajectories. Roberts and Stewart's (2018) reconceptualization of H. sapiens as "generalist specialists" perfectly illustrates this. Present-day $H$. sapiens have the cognitive potential to adapt to the same range of resources selected by generalist species, such as broadspectrum scavengers, but individual populations and social units tend to specialize in specific resource webs, often engaging intergenerational knowledge acquired over hundreds or thousands of years. These specializations are not static and H. sapiens are adept at forming new connectivities to novel environments, reorienting our own behavioral trajectories to address challenges, to the extent that we could describe the species as "hyper-adaptable" (Hiscock 2015), "infinitely adaptable" (Veth 2005), or "behaviorally plastic" (Roberts and Amano 2019). Crossing water gaps to explore new lands is one activity that often encourages the expression of this plasticity and experimentation with new adaptive behaviors, as it is in other species pushed to the edge of their ecological range (Kozlovsky et al. 2015; Liebl and Martin 2014; Webb et al. 2014).

Drawing on cognitive ecology literature, I adopt the term "adaptive flexibility" as a way to describe the reorientation of behavioral trajectories for adaptive success when humans move into new environments or at times of perceptible environmental change. Adaptive flexibility is an important response in many species that enter novel environments (Reader and Laland 2002). It allows colonizing populations to exploit novel food sources and habitats as they create new ecological niches for themselves (Price et al. 2008). Substantial adaptive flexibility is identifiable among recent human groups, with proxies coming from changing resource selection, foraging strategies, shelter selection, group size, and risk reduction strategies. Crossgenerational cultural niche construction has been central to hominin evolution, as we are able to alter our behaviors in response to the environments that we ourselves engineer (Boivin et al. 2016).

There are inevitably temporal lags in adaptations to novel environments (Laland and Brown 2006). These adaptations are expressed on the individual level, where new behaviors are innovated, and on the social level, where innovations are shared within and between groups. It is one form of rapid response that can operate on the scale of an individual's lifetime, which may be interrelated with multigenerational genetic and physiological changes (Dukas 1998; West-Eberhard 2003). This type of innovation paired with social learning can be advantageous when environments change, or new environments are explored, but it can be disadvantageous when environments change so rapidly that prior learning is outdated (Dukas 1998).

The adaptive flexibility hypothesis (Wright et al. 2010) states that the number of behavioral variants will be high during the introduction stage of colonization due to adaptive innovations and then will gradually decline as successful behaviors are shared within the group during the establishment period of population growth (Fig. 1). This happens because sharing successful behaviors between individuals is favored over further adaptive innovations and results in a consolidation of, and 
Stage of

colonization Introduction Establishment Expansion

The Adaptive Flexibility Hypothesis

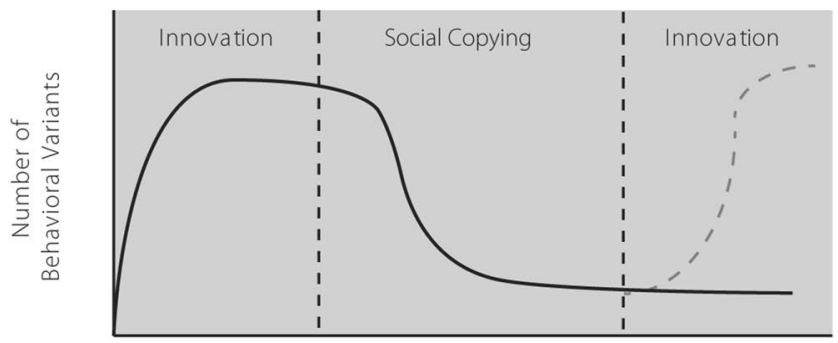

daughter

populations

founding population

Alternative 1: Constant Flexibility

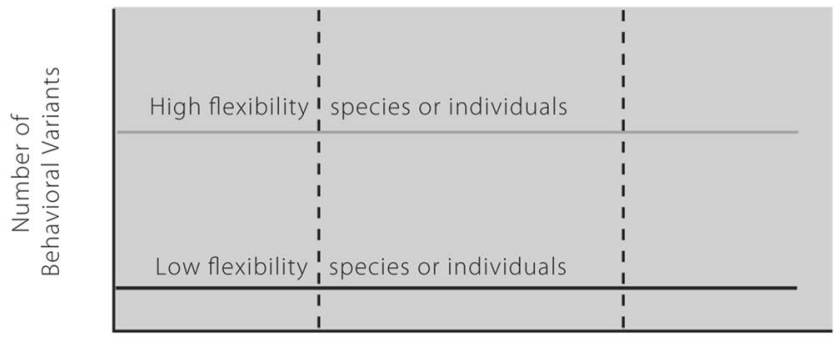

Alternative 2: Skill Pool Effect

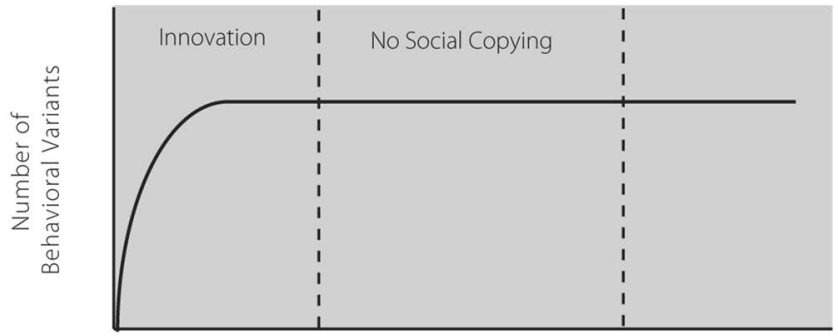

founding and

daughter

populations

Alternative 3: Strong Cultural Traditions

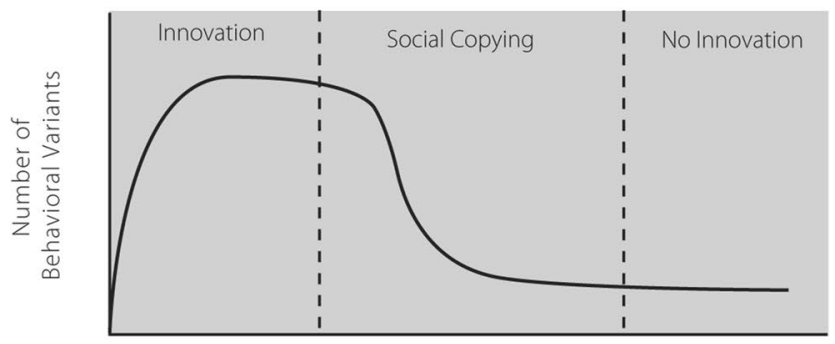

founding and

daughter populations

Fig. 1 The adaptive flexibility hypothesis (adapted from Wright et al. 2010) 
decline in, in-group behavioral variability. It is possible that adaptively redundant or "nonrational" behaviors also may appear and be shared within groups without compromising that founder population. Later, when the founder population grows large enough, it enters an expansion stage (cf. Wright et al. 2010 "invasion" stage), whereby daughter populations are spawned, encouraging further behavioral variations. This model emphasizes the historical and ecological contingencies of adaptation, modified by individual and shared experiences in the landscape (social and environmental). It also emphasizes that, contrasting with many models of modern human behavior, adaptive flexibility is not intrinsic to human nature: it can be variable over a lifetime, across generations, and between populations. This fits well with current trends in anthropology, which suggest behavior is not hard-wired and biologically constant within species but is a dynamic transformation of continuous cultural, material, and environmental engagements (Gosden and Malafouris 2015; Ingold 2003; Malafouris 2013). It also provides a diachronic explanation for how the "generalist specializations" of $H$. sapiens can emerge, with the capacity for distinct behavioral change in the face of new ecological surroundings, followed by periods of increasing specialization that becomes part of that ecology.

There are several conceptual alternatives to the adaptive flexibility hypothesis (Fig. 1, from Wright et al. 2010). In Alternative 1, some populations might consistently operate at high levels of flexibility or inflexibility regardless of context; in Alternative 2, others might display initial innovation, but not share these innovations within the group; or in Alternative 3, some populations might innovate and share behavioral variations but not exhibit increased diversity within daughter populations.

Coastal and maritime subsistence strategies and making water crossings to target resources previously out of reach are expressions of adaptive flexibility in novel environs. However, is this adaptive flexibility unique to $H$. sapiens? To what extent did other species also make deliberate water crossings, adapt to island life, and incorporate marine resources into their subsistence strategies? As Leppard and Runnels (2017) state, this topic is of profound importance for how we understand hominin cognitive evolution.

\section{Typologizing Water-Crossing Behaviors}

The history of thought on hominin capacities for water crossings has ebbed and flowed over the past century (see Erlandson 2001). Fundamentally, water crossings do pose distinct challenges for human mobility, which often promote cultural and demographic isolation (Fitzpatrick and Anderson 2008). In the wake of early island biogeographic approaches (e.g., Cherry 1981), Leppard (2015a, b) synthesizes this standard model, positing that bodies of water formed important barriers to hominin expansion prior to the Late Pleistocene and that even early water crossings were structured on a global level, with larger continental islands being colonized first, as they present more resource abundance and lower economic risk for incoming colonists. This model suggests that intentional seagoing arose solely among $H$. sapiens (or possibly $H$. neanderthalensis), following the emergence of "modern cognitive architecture" (Leppard 2015b). According to Leppard (2015a), intentional 
dispersal required projection of future action, group planning, and composite technology. Projection of future action, or thinking ahead about possible realities, is always informed by previous experience and is a core feature of present-day H. sapiens water crossings. As Leppard notes, it is a great leap from standing on the shore and wondering about what lies over the horizon, to actually mobilizing oneself with various tools to get there. Group planning not only involves social living and residing in groups large enough to form viable founder populations but also the ability to express complex ideas of abstraction (i.e., possible realities) and to convince others to achieve mutual goals. Composite technology involves combining component parts that by themselves are insufficient for the intended function, which implies something about the cognitive plasticity of the makers: the ability to project future action or to think ahead of the material (Leppard 2015b).

Many nonhuman animals raft or swim to new landmasses (Fig. 2). In this sense water crossings are not exceptional to hominins, rather it is the nature, scale, and deliberateness of the crossings that sets our species apart (Leppard 2015a). A central distinction here is whether dispersals to new pieces of land were intentional. Following biogeographic theory, Leppard (2015a) divides maritime dispersal into "passive" and "strategic" (cf. Ruxton and Wilkinson 2012, "accidental" vs. "planned"). Passive dispersals involve no specific cognitive processes about the dispersal itself, while strategic dispersals are self-reflexive, involving cost-benefit projections about the water crossing and subsequent access to new resources. However, it is unclear if a group of hominins raft or swim to new land, forming a viable founder population,

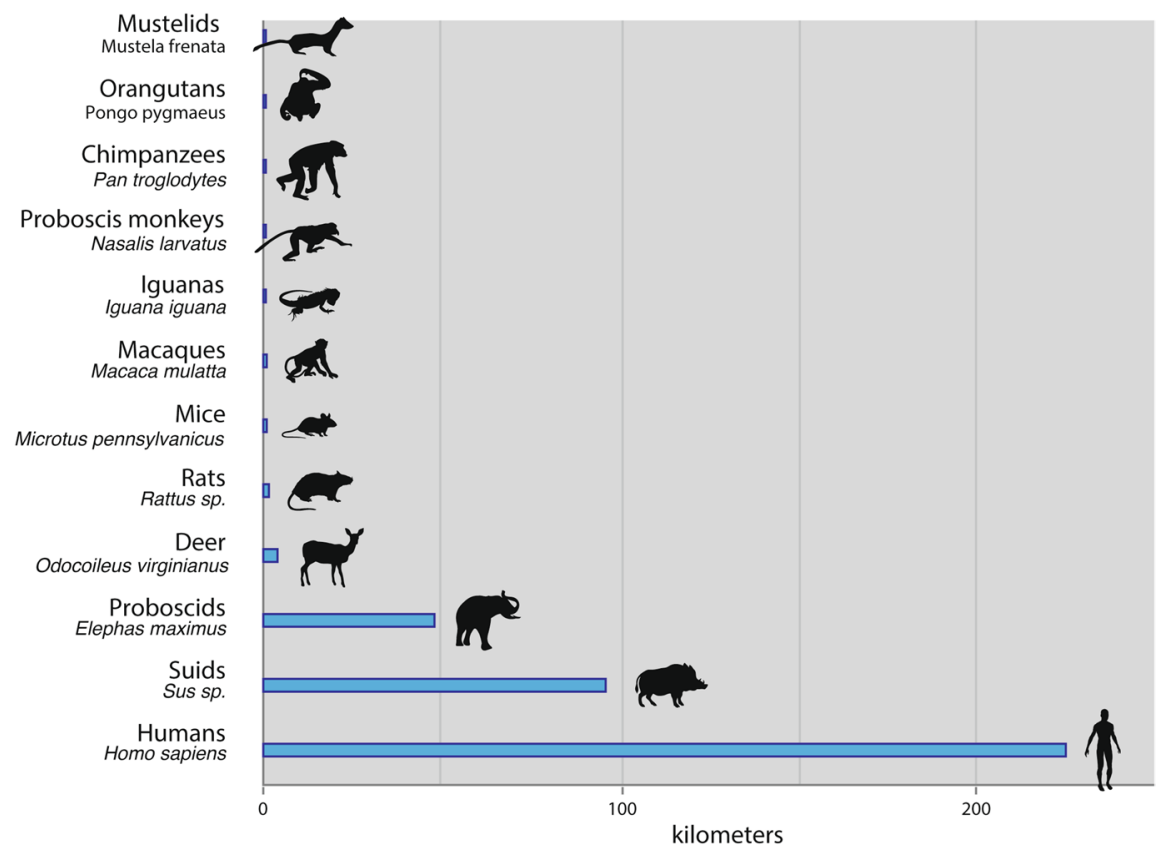

Fig. 2 Swimming ranges of human and nonhuman animals (based on data in Bender 2015; Schoener and Schoener 1984) 
whether they chose to do so in the same way that $H$. sapiens make decisions, and whether this would be considered passive or strategic.

In contrast, in a multispecies model proposed by Runnels (2014) in the Mediterranean and Bednarik (2003) in Wallacea, strategic, long-distance water crossings are viewed as distinctly within the capacity of not only $H$. sapiens but also $H$. neanderthalensis, $H$. heidelbergensis, $H$. erectus, and the ancestors of H. floresiensis. Erlandson (2001) demonstrates that aquatic resources, including fresh water, shellfish, fish, reptiles, and amphibians, have been important to our genus since the Plio-Pleistocene, and that hominins would have experimented with water crossings (even short river crossings) during any major dispersal around the planet. From this revisionist perspective (see Leppard 2015b), archipelagos are described as express highways rather than barriers. These models are ultimately borne from paradigmatic shifts in the late 20th century, which emphasized coastal and island adaptations in human migration narratives, especially as they pertain to the "southern dispersal route," the rapid colonization of Sahul by $H$. sapiens, coastal occupation by $H$. neanderthalensis, and the peopling of the Americas (Bailey and Milner 2002).

I contend that in this debate-the archaeological questions about which populations made deliberate water crossings and which species succeeded with strategic oceanic colonizations - two behavioral processes have been conflated. We can tease apart these questions by examining water crossings as mobility behaviors and island habitation as colonization processes. Most of the Pleistocene record is devoid of direct evidence for maritime mobility behaviors (i.e., boats), and we rely on indirect site distributions, artifact sourcing, and isotopic data relative to Pleistocene sea levels. To characterize these behaviors, Broodbank (2006) puts forward a scalar typology: "seagoing" indicates the simplest sea-crossing techniques, "seafaring" indicates more proficient mid-range technologies, and "voyaging" indicates highly skilled, intentional, and often long-range navigation. I also incorporate the term "water crossing" where there is insufficient evidence to describe the scale and complexity of how a water gap was crossed. These mobility behaviors often correspond with, but are not necessarily causally linked to, the scale and success of colonization, for which we have distinct evidence in the form of paleoenvironmental change, faunal extinctions, tool modification, ancient genetics, settlement scale and longevity, and lithic landscape learning.

Using such datasets, we can start to address the nature, timing, and scale of water crossings made by different regional populations throughout the Pleistocene and how they articulate with colonization processes in new environs. Using the adaptive flexibility hypothesis, we can posit that hominins, whether they crossed water gaps intentionally or not, would have displayed wider behavioral variability during introduction phases of the colonization process, perhaps sampling from varied and novel food webs and experimenting with new raw materials to overcome technological challenges such as constructing watercraft to further expand resource patches. Perhaps counterintuitively, these innovations would come at the time when a founder population was small and most sensitive to local extinction (Leppard 2015c, 2016). The variability and effectiveness of these innovations, including additional water crossings, is reflective of the scope of adaptive flexibility expressed within each population and the tempo of these 
adaptive changes. I put forward two testable models (Fig. 3). The "rapid flexibility hypothesis" stresses hominins, particularly $H$. sapiens, are highly adept at changing to new environments. They are able to alter subsistence and technological behaviors so rapidly (within a few generations or several hundred years) that the switch is archaeologically undetectable. This results in hominins arriving in coastal areas, monopolizing aquatic resources, and developing water-crossing abilities very quickly. A second, alternative model is the "gradual modification hypothesis," which stresses that hominins, including $H$. sapiens, are adaptively flexible, but major subsistence and technological changes such as water crossings and maritime lifeways derive from long-term behavioral trajectories and can take several millennia, or tens of millennia to emerge, especially if there is no immediate incentive for such behavioral change.

Stage of

colonization Introduction Establishment Expansion

The Rapid Flexibility Hypothesis

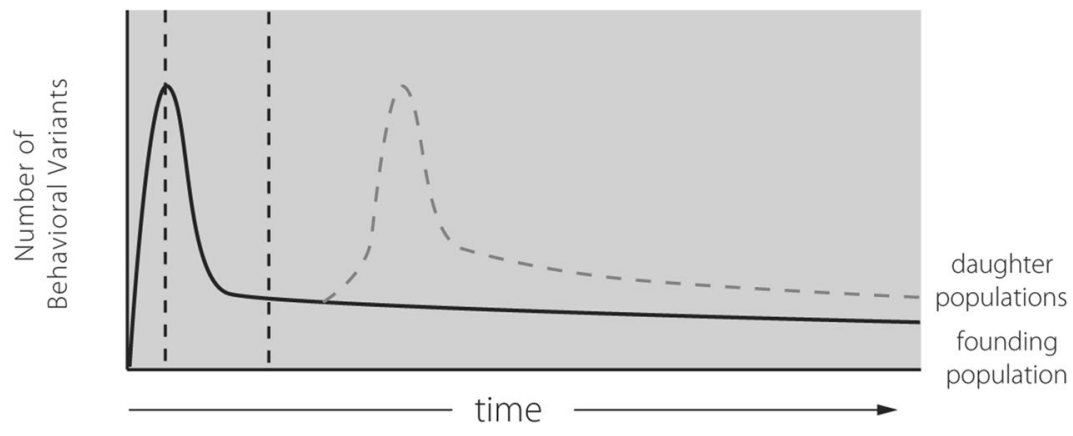

The Gradual Modification Hypothesis

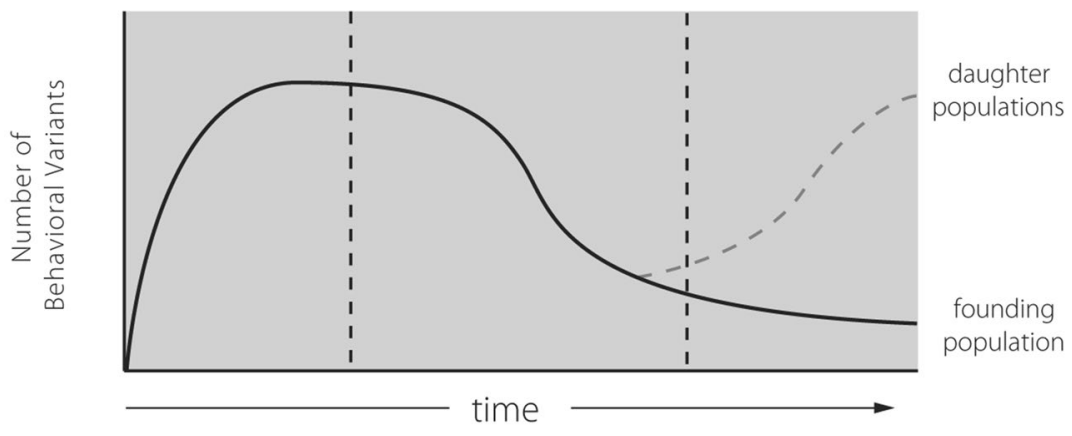

Fig. 3 Two models for the tempo of adaptive flexibility 


\section{Global Environmental Changes}

To understand the rates of adaptive flexibility within different regional populations as it pertains to water crossings, it is crucial to understand the rate of environmental change through archaeological time (Fig. 4). This has direct implications for the distance required to get from one landmass to another and the ecologies encountered on arrival. Since the beginning of the Middle Pleistocene, global sea levels have fluctuated over $130 \mathrm{~m}$ approximately every 100,000 years during glacial/interglacial transitions (Bintanja et al. 2005). It is likely that Marine Isotope Stage (MIS) 2 (the Last Glacial Maximum, LGM), MIS-6, MIS-12, and MIS-16 were the most extreme glacial maxima, which resulted in the lowest eustatic sea levels as well as ice sheet corridors in the Northern Hemisphere, while MIS-5e, MIS-9, and MIS-11 were the warmest interglacials with high sea levels (Murray-Wallace and Woodroffe 2014, p, 262). Although many MIS-3 and MIS-4 paleobeaches are now submerged, limiting

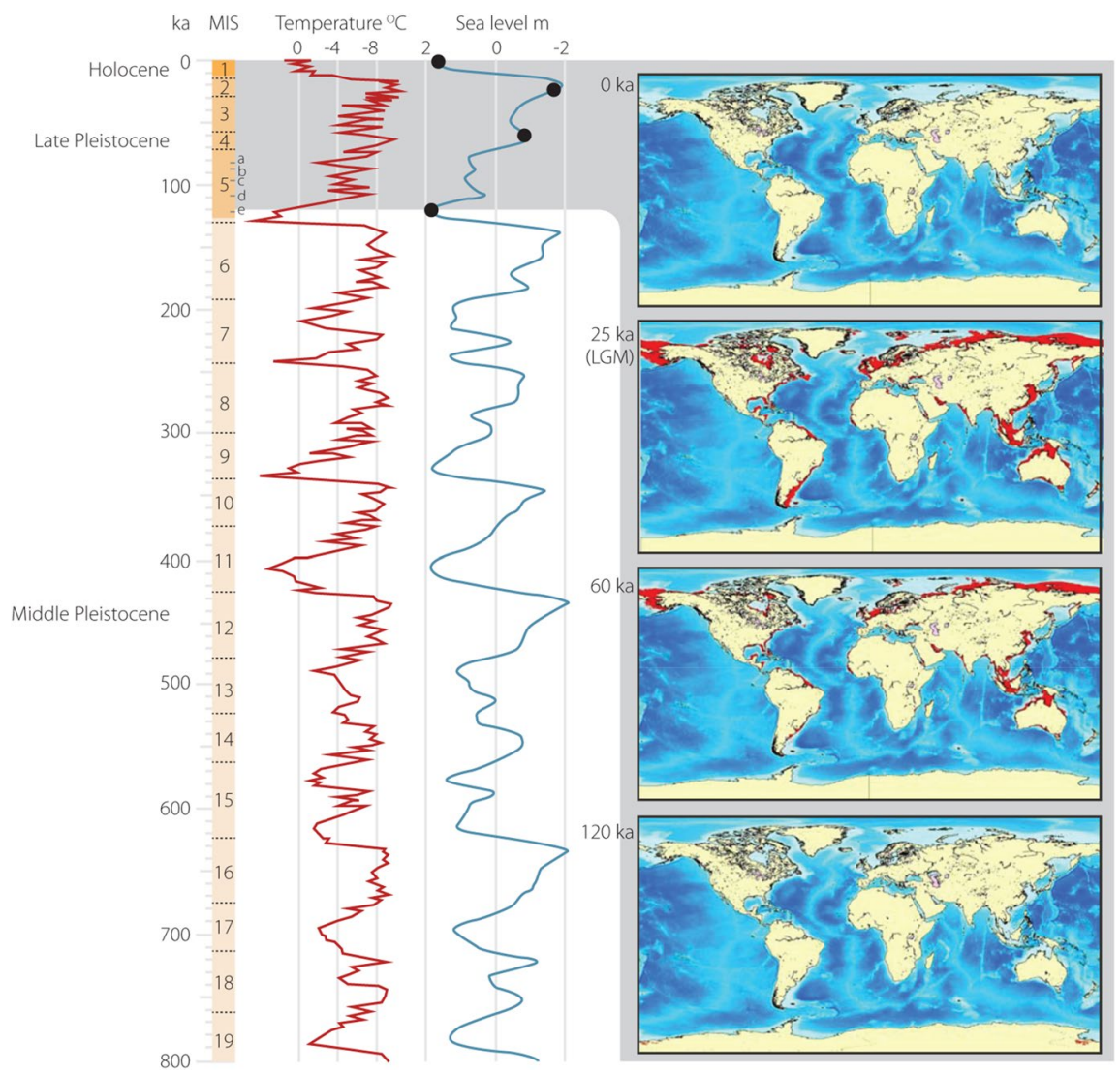

Fig. 4 A timeline of global temperate and sea-level change from the Middle Pleistocene to Holocene. Climate curve data derive from Lowe and Walker (2014) and elevation maps derive from Zong (2015), which show land exposed by glacial cycles in red 
our ability to understand major dispersals out of Africa (Bailey and Milner 2002), the shorelines of MIS-5e, MIS-13, and MIS-15 would be similar to today, while others such as MIS-11 would be over $10 \mathrm{~m}$ higher than present and some way inland (Bowen 2003). Regionally, there also was substantial variation in relative sea levels due to local emergence rates and more dramatic tectonically induced uplift and subsidence events (Murray-Wallace and Woodroffe 2014, p. 278).

In Asia, the Sunda shelf, forming an extension to mainland Southeast Asia, has been repeatedly submerged and exposed during marine transgressions. This turned the islands of Borneo, Java, Sumatra, Taiwan, and the seabed of western Indonesia into a large continental peninsula the size of present-day Europe, although the Philippines always remained insular (Sathiamurthy and Voris 2006). To the east, the islands of New Guinea and Tasmania were attached to Australia during low stands, forming the continent of Sahul, with the Gulf of Carpentaria becoming a large paleolake (Summerhayes and Ford 2014). Located between Sunda and Sahul, Wallacea has always consisted of islands such as Sulawesi, Flores, Timor, Seram, Halmahera, and parts of the Raja Ampat group, separated by deep sea trenches. Off Sahul's northeast coast, the Bismarck Archipelago and Solomon Island chain also were always separated from the mainland. Farther north, Japan was part of a larger landmass and variously connected to continental Eurasia, although the Ryukyu Islands between Kyusu and Taiwan were predominantly insular (Takamiya et al. in press), while the Beringia land bridge accompanied by ice sheets connected eastern Eurasia to the Americas during glacial periods; the two continents were separated most recently by approximately 15,000 years ago (Hopkins 1982).

In the Mediterranean, following the Messinian Salinity Crisis, the Zanclean Deluge refilled the basin with water from the Atlantic, forming many of the islands in the region about 5.33 million years ago (Blanc 2002). Although some islands such as Crete, Gavdos, and Cyprus were clearly separated from mainland Greece throughout the Pleistocene, it is uncertain if other islands were due to variable rates of tectonism (Benjamin et al. 2017). Lykousis (2009) suggests that the margins of the Aegean have been subsiding for the past 400,000 years ago at rates of 0.7-1.9 m per 1000 years, particularly during MIS-12 and MIS-10-MIS-8. During these Middle Pleistocene glacial periods, 50-60\% of the present-day Aegean would have been attached to the mainland, part of a basin with extensive drainage systems, lakes, and river deltas.

Sea-level change and global climate shifts also were core mechanisms that shaped biogeography during the Pleistocene (Hanebuth et al. 2011). During glacial periods, lowered sea levels broadly correspond with aridity and slow sedimentation rates, especially in Sahul (Vannieuwenhuyse 2016) and savannah grasslands in Sunda and highland New Guinea (Louys and Turner 2012). Conversely, during the climatic ameliorations of interglacial and interstadial periods, stable increases in sea level, particularly in equatorial zones, led to expansions of coral reefs, swamps, forests, and wetlands rich in littoral resources (Chappell 1993) and massively reconfigured river systems and estuarine environments (Voris 2000). These periods also were associated with increased humidity, weathering, and pedogenesis (Burckle 1993). Warming from about 14,500 years ago was typically unstable and, in the tropics, was associated with severe monsoon and drought conditions, with modern Holocene 
sea levels established approximately 8,000 years ago. These variable and changing Pleistocene environments formed the backdrop for the very first water crossings within our genus.

\section{The Global Evidence for Pleistocene Water Crossings}

\section{Getting Our Feet Wet in Africa, Arabia, and Southern Eurasia}

Africa was the evolutionary hub for a number of different Homo species, where riverine and lakeside aquatic resources, including drinking water and shellfish, were opportunistically targeted since the Early and Middle Pleistocene (Erlandson 2001). Excavations at Blombos Cave in southern Africa show that Middle Stone Age hominins were beginning to adapt to the coastal zone, which included diving for marine shells, catching large littoral fish, hunting seals, and probably scavenging beached dolphins, in addition to targeting a wide array of terrestrial animals (Henshilwood et al. 2001). At the Pinnacle Point site, also in southern Africa, the move to the coast occurred 164,000 years ago as a response to harsh aridity, although the change to targeting marine resources, including shellfish and perhaps even processing beached whales, developed over time, becoming prominent 110,000 years ago (Marean et al. 2007; see also Marean 2014).

A change to coastal subsistence, especially collecting shellfish and scavenging large marine mammals, has important implications for adaptive flexibility, with a shift to fixed resources enabling short-term sedentism. Additionally, reliable protein sources, and the fatty acids common to shellfish in particular, may have profoundly affected the evolution of the brain (Kyriacou et al. 2016). It remains unclear if this change at the southern African sites represents the same continuous lineage of hominins or marks a distinct replacement by separate, coastally adapted groups.

Recent excavations on the north coast, along with genetic work, have pushed back our species, H. sapiens, to over 300,000 years ago (Hublin et al. 2017; Schlebusch et al. 2017), and there is substantial evidence throughout the continent for subsequent innovations such as pigment use (Watts et al. 2016), blade production (Wilkins and Chazan 2012), future planning (Texier et al. 2010), and marine shell ornamentation (d'Errico et al. 2009) thought to mark a stretching of behavioral plasticity.

As different African lineages moved north through the Levant, they maintained physical and symbolic connections to the sea. There is evidence for perforated gastropod shells from Skhul in the Levant and shell beads from Oued Djebbana in northern Africa 100,000-135,000 years ago (Vanhaeren et al. 2006). Later shell tools at Ksâr 'Akil dated to 50,000 years ago, signaling a pulse of Homo sapiens into northwest Eurasia through the Levantine corridor (Bosch et al. 2015). There is no direct evidence for hominins making water crossings on their way out of Africa, but the Bab el Mandab route through the Red Sea remains a viable possibility (Armitage et al. 2011). The Red Sea has been open to the Gulf of Aden since at least MIS-12, 440,000 years ago (Lambeck et al. 2011), but during low stands in MIS-5-MIS-6, crossings of about $4 \mathrm{~km}$ were possible. At Abdur, along the Eritrea coast of the Red Sea, early Middle Stone Age artifacts in an emergent reef terrace are dated by U-Th 
dating to about 125,000 years ago, and faunal remains demonstrate these people were coastally adapted (Walter et al. 2000), in accord with evidence for climatically induced movements in southern Africa, due to fluctuating glacial cycles. Some outof-Africa expansions may reflect pull factors into new coastal areas, with competition driven by increased population sizes and sedentism related to coastal adaptation (Walter et al. 2000).

It is now thought that there were a number of dispersals out of Africa by different hominin populations, both terrestrially and coastally. The Sahel vegetation corridor linking Africa, Arabia, and South Asia may have formed one route following abundant coastal resources into Southeast Asia. This route was reliable on a latitudinal basis, but over the long term this dispersal would have been punctuated by environmental variation, particularly glacial cycles (Timmermann and Friedrich 2016). Hypothetically, such environmental instability alongside a diet rich in omega acids may have encouraged ongoing adaptive flexibility in a coastal context. However, no direct evidence exists for maritime technology along this coastal route, and a swathe of new sites in southern and eastern Eurasia now challenge the importance of the coastal model (e.g., Bae et al. 2014; Li et al. 2018; Liu et al. 2015; Shen et al. 2013). The sites, dating to c. 130,000-70,000 years ago, indicate there was an earlier exodus of $H$. sapiens from Africa, perhaps primarily terrestrial, with migrations along southern Eurasia representing a relatively recent dispersal within our genus.

The only tentative evidence for strategic Pleistocene seafaring in the region comes from Madagascar, where Hansford et al. (2018) claim elephant bird (Aepyornis) long bones dated to $>10,500$ years ago (Table 1) display peri-mortem butchery marks, potentially demonstrating $H$. sapiens crossed the Mozambique Channel to Madagascar around the Terminal Pleistocene and Early Holocene. The evidence is still contentious, however, and Anderson et al. (2018) present counter-arguments for an initial Late Holocene colonization from Island Southeast Asia. A critical review of Madagascar's radiocarbon chronology finds that it was settled by at least the Late Holocene, but Early Holocene occupation is also likely (Douglass et al. in press). Further paleoenvironmental and zooarchaeological analyses are needed to clarify this important point, which has major implications for how we understand the tempo of island megafaunal extinctions (Douglass et al. 2018), as well as whether humans around Africa could navigate substantial distances and out of sight of land (Table 2). The Madagascan data are outliers, and most evidence for open water crossings around Africa itself is not present until well into the Holocene (Mitchell 2004). In future, it will be crucially important to establish if marine lifeways, and perhaps seafaring, emerged gradually in Africa and along the southern dispersal route during the Pleistocene, or if they appeared suddenly in the east, as a response to humans encountering large archipelagos (Fig. 5).

\section{Drifting and Voyaging Through Southeast Asia}

The earliest secure global evidence for open water crossings comes from Island Southeast Asia. Because of the region's steep geomorphology, records of Pleistocene island and coastal occupation survive, where in other parts of the world it is 


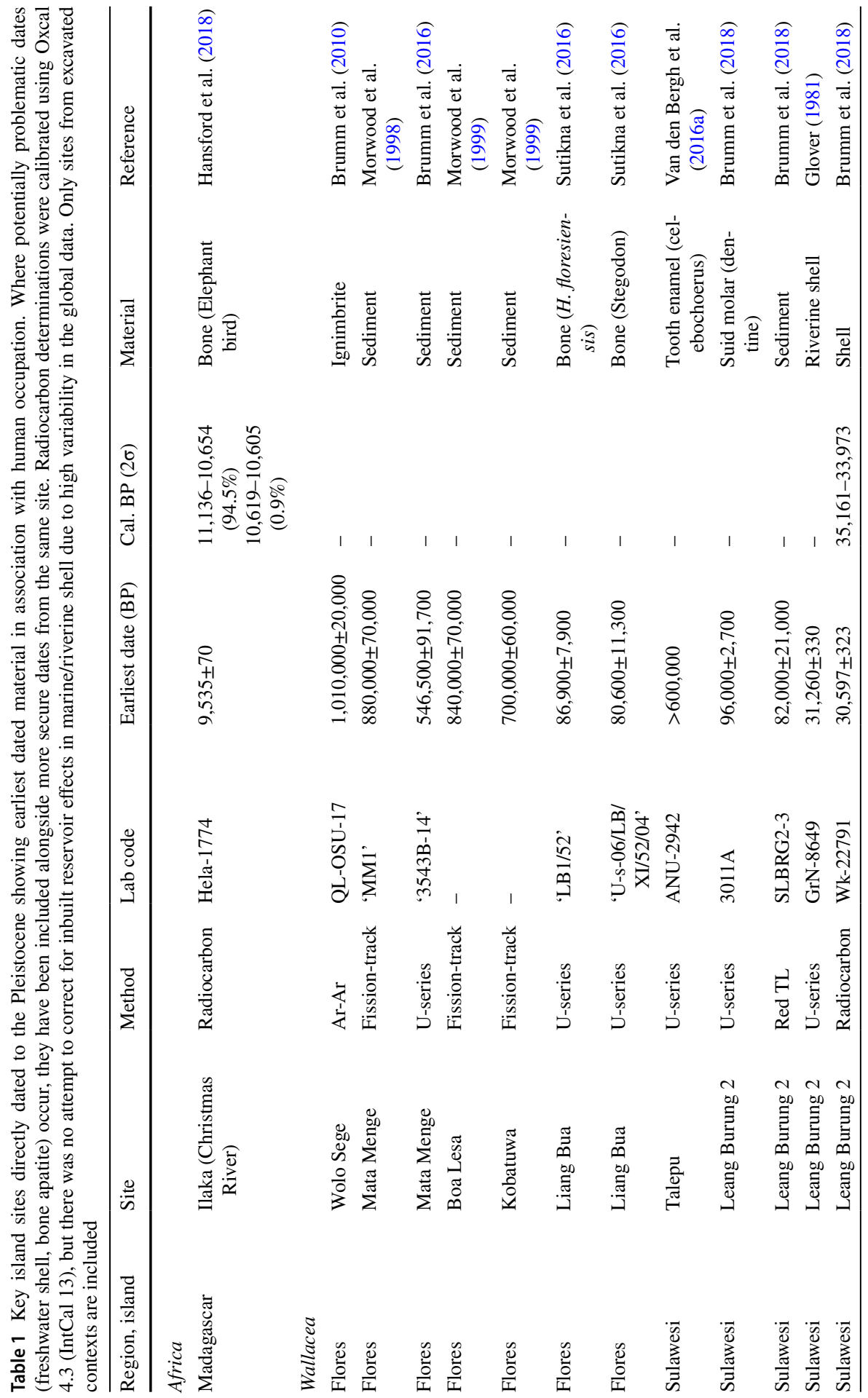




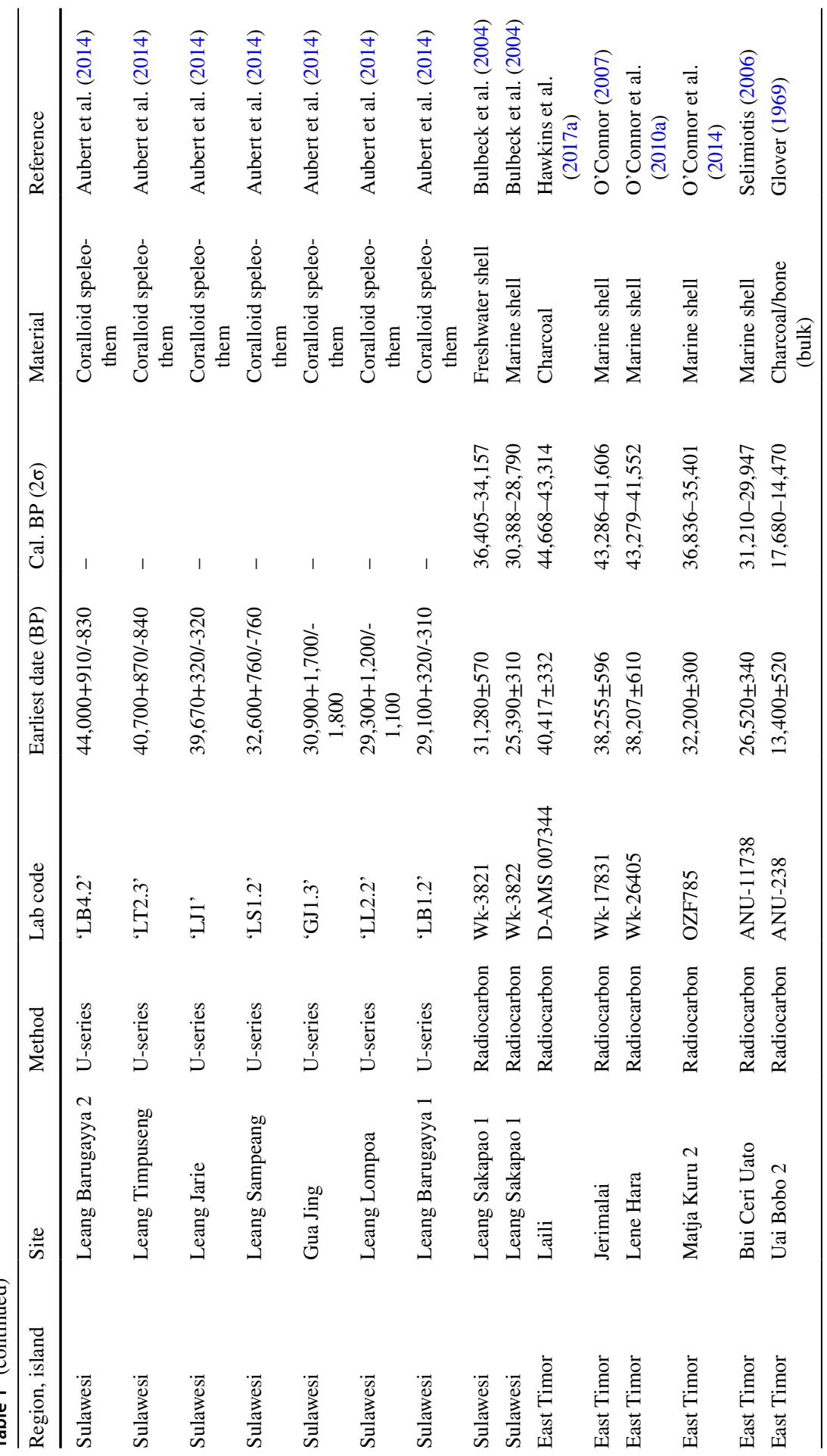




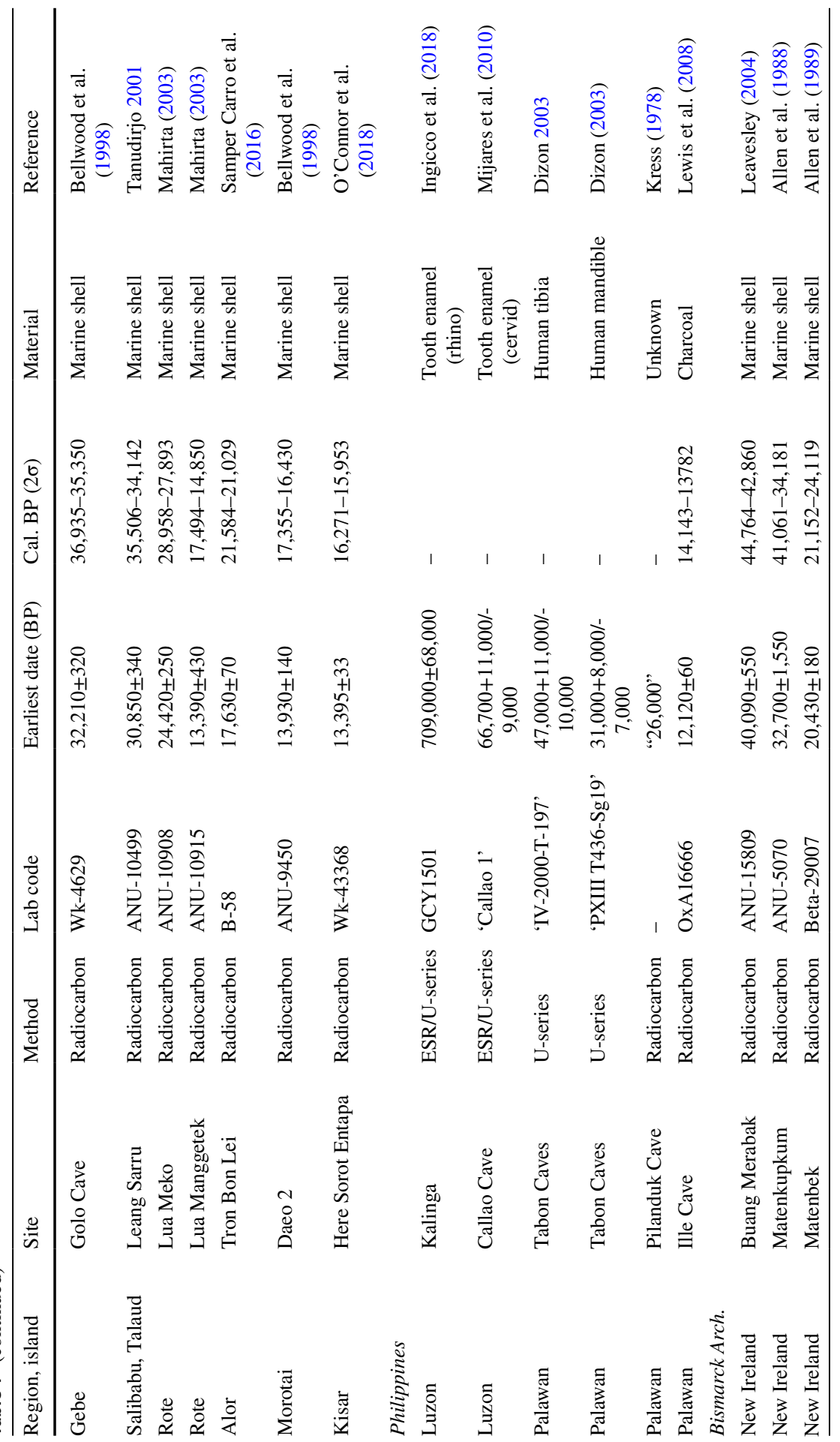




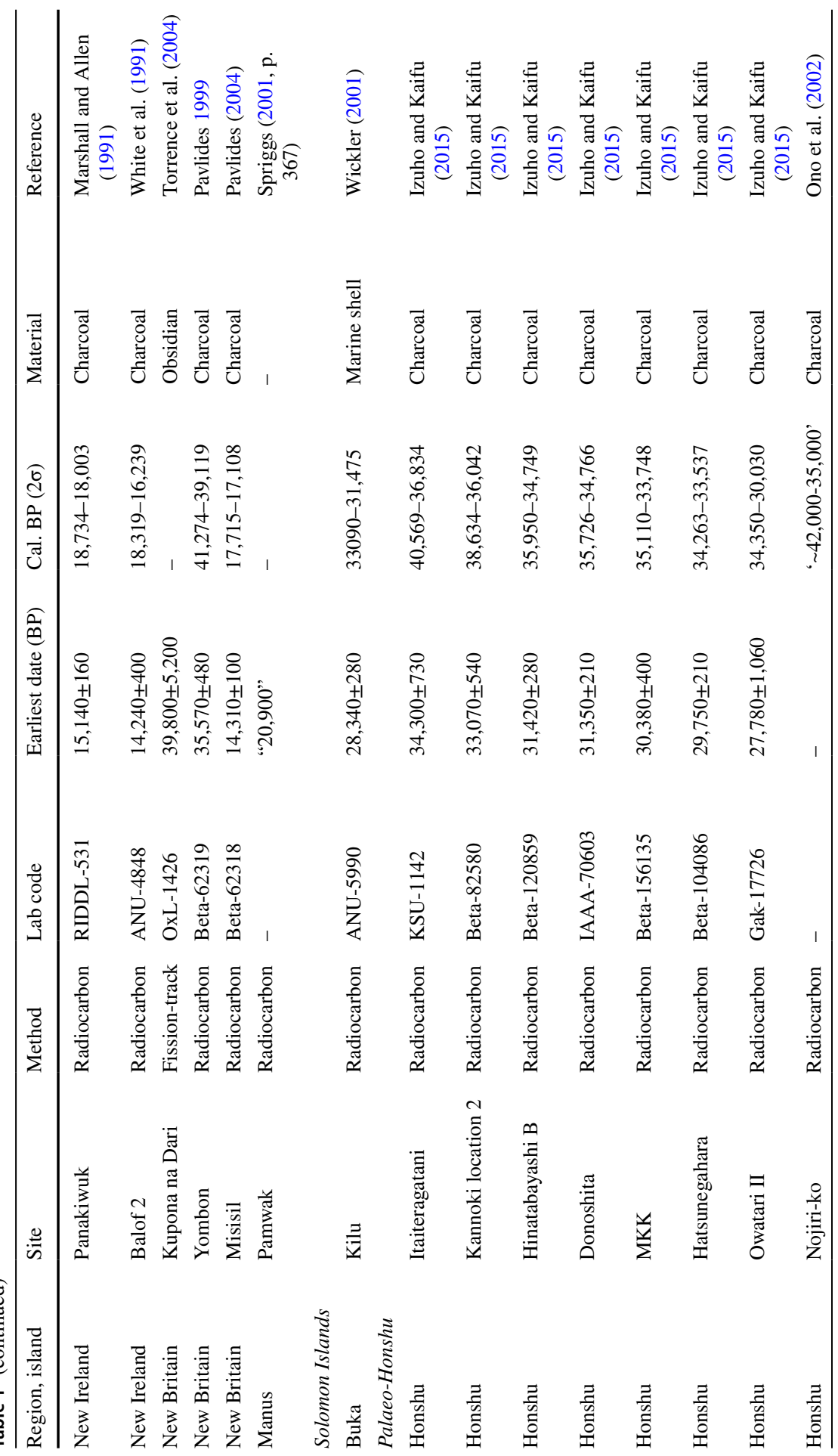




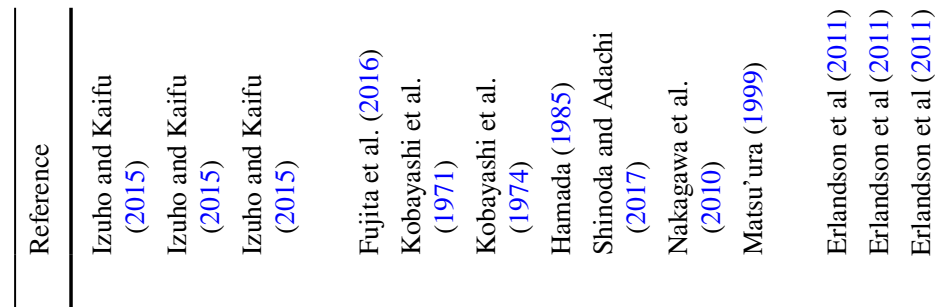

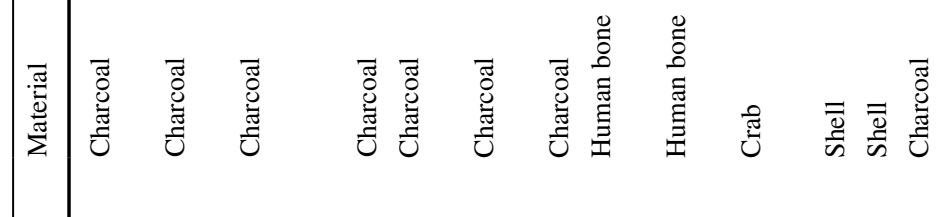

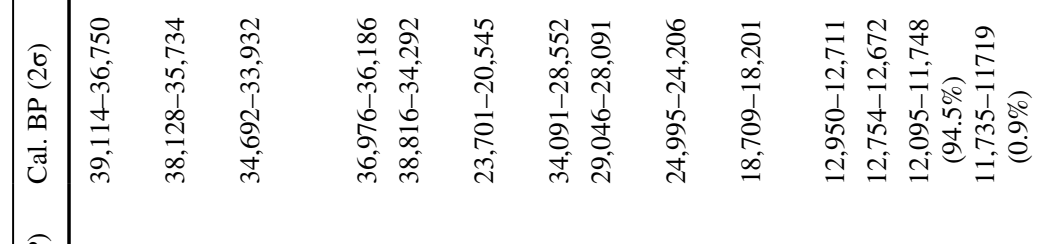

ิิ)

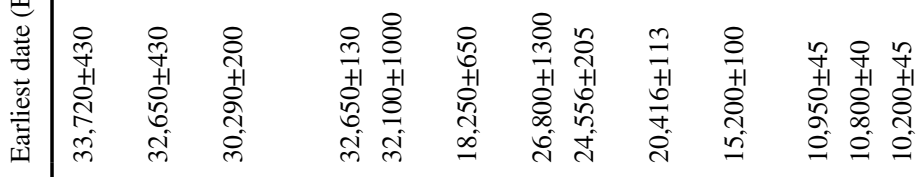

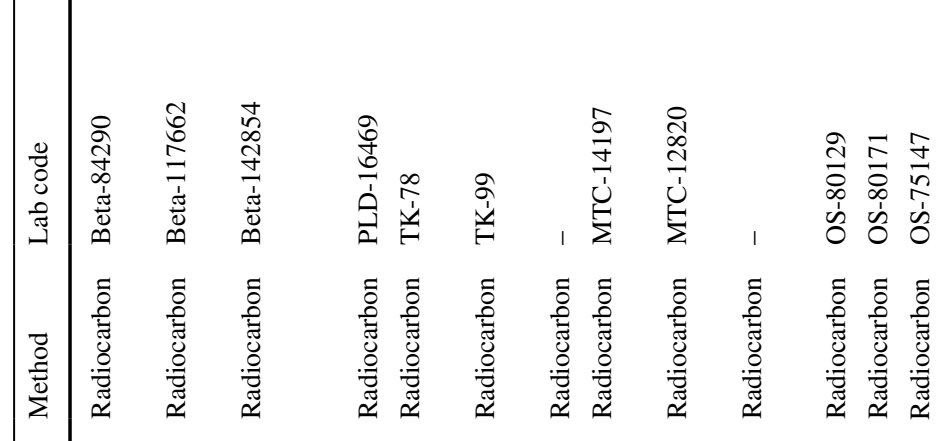

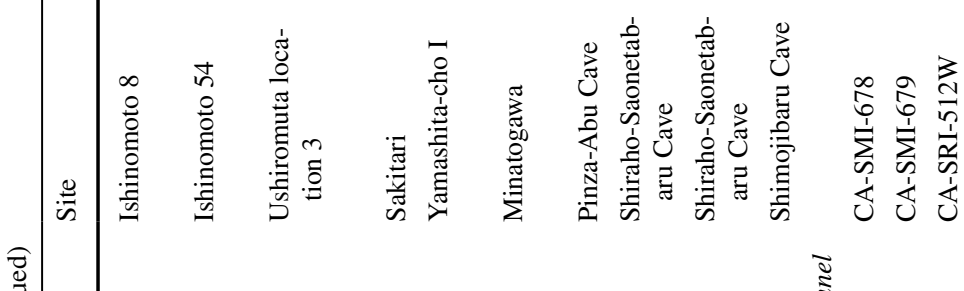

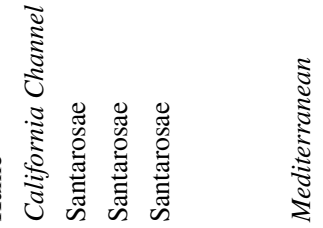




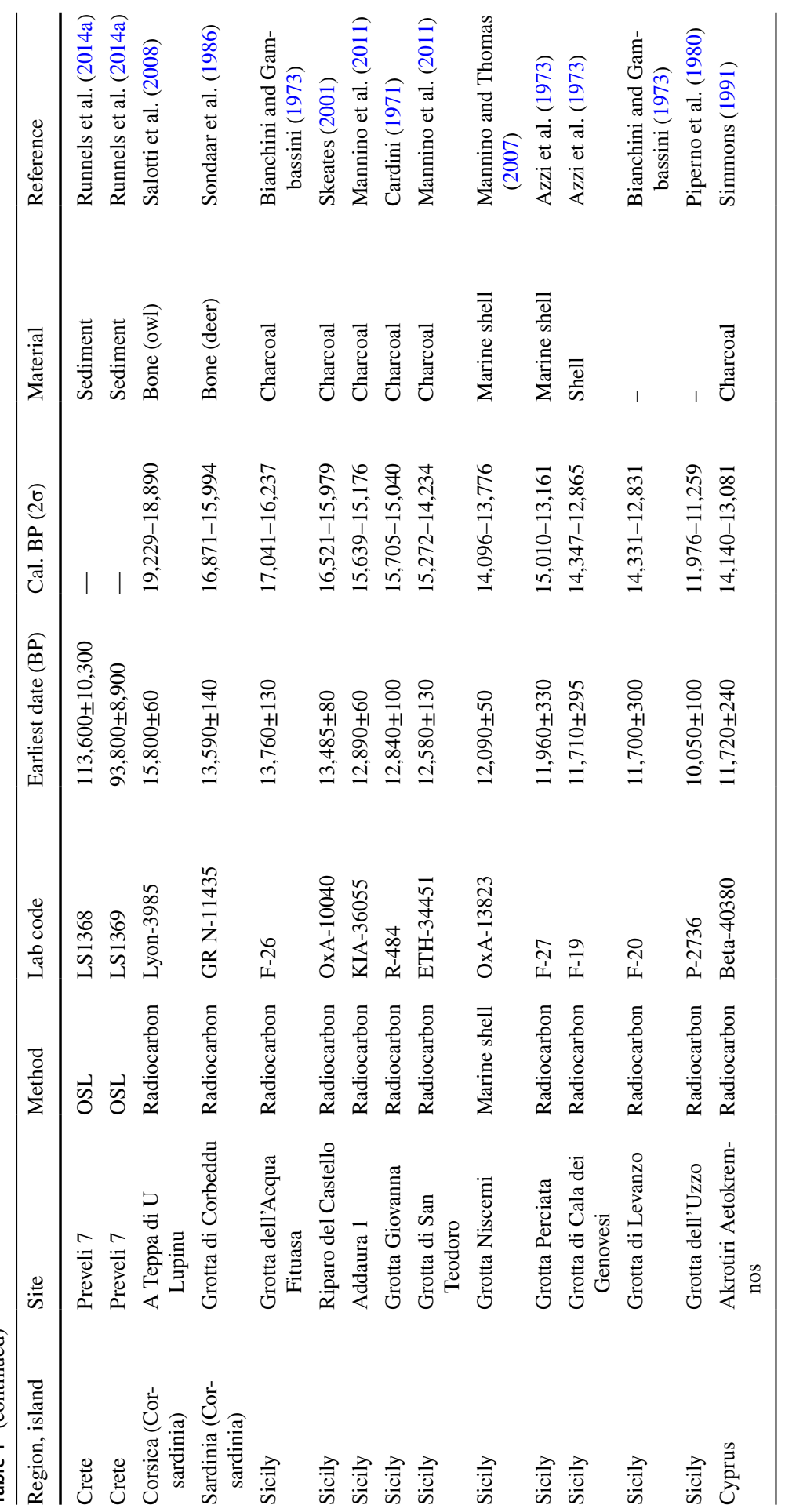




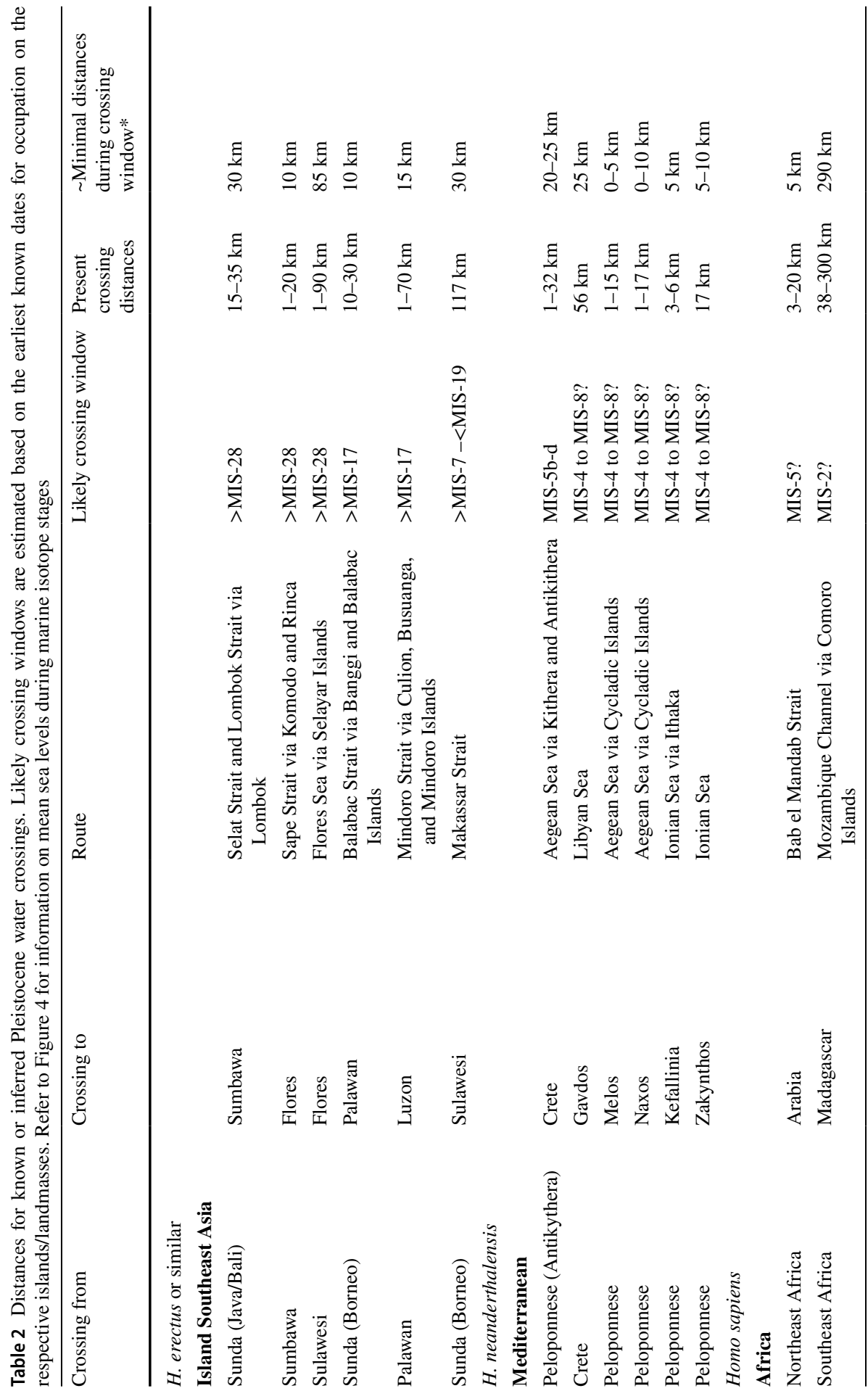




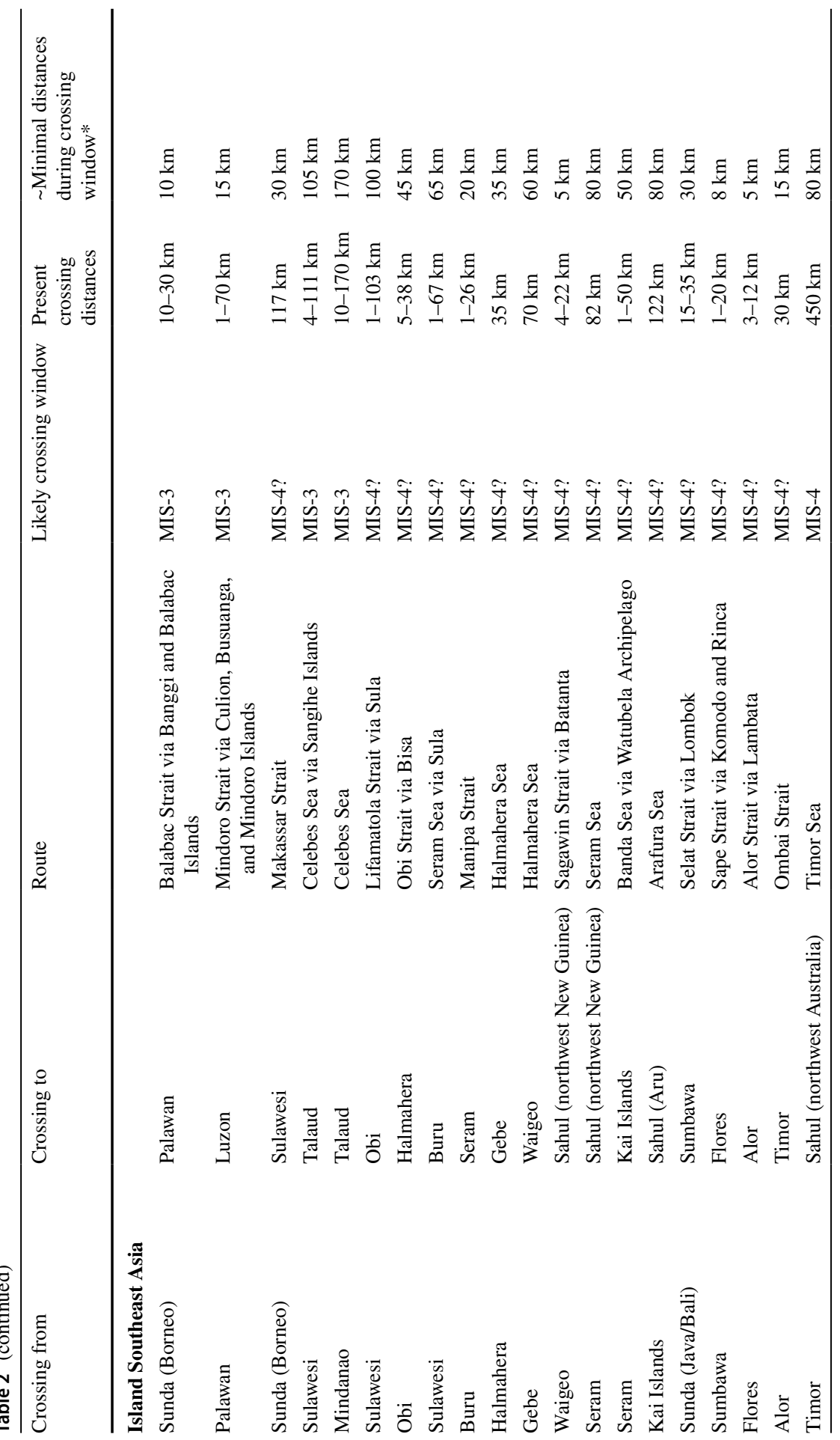




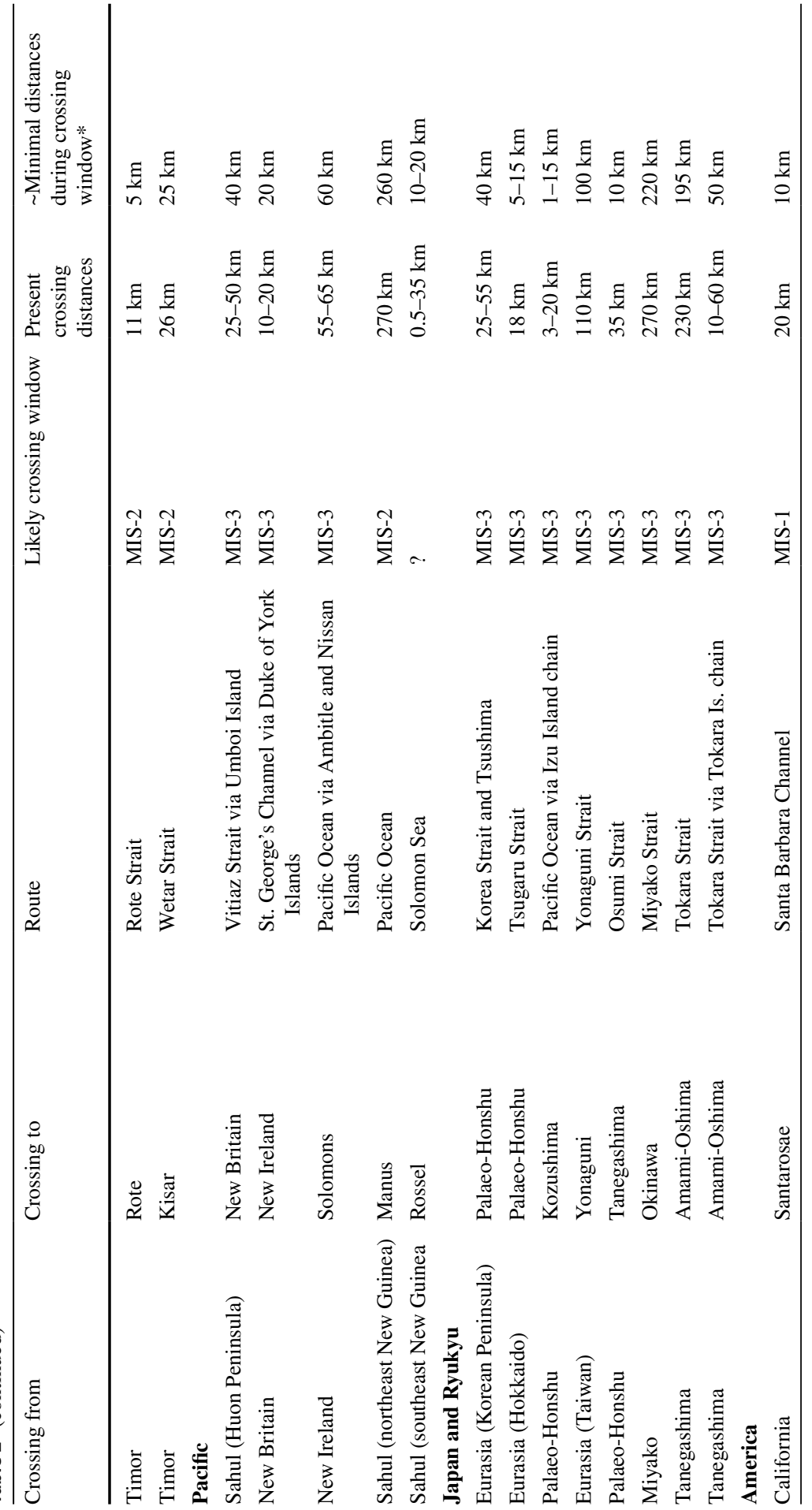




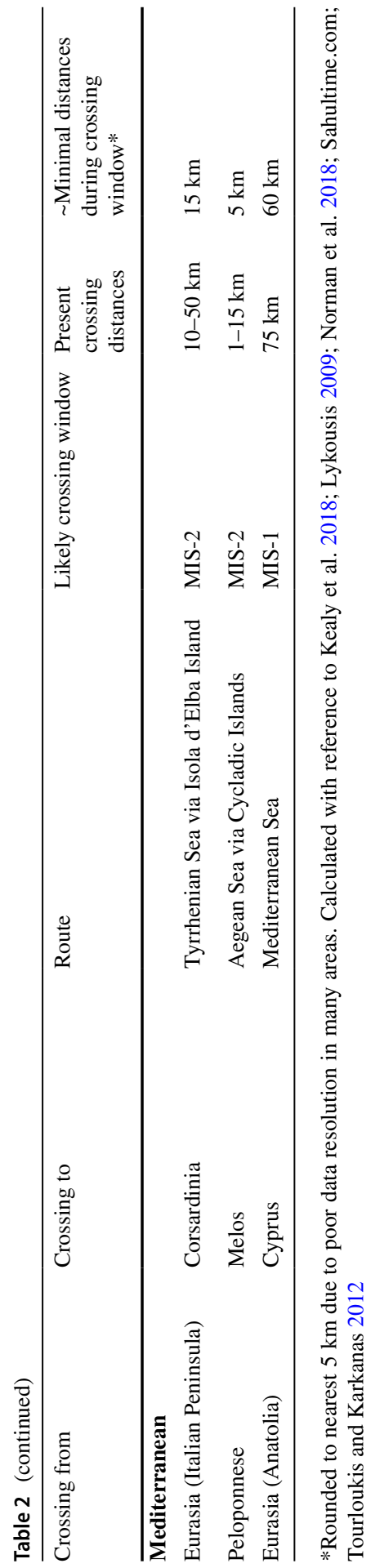




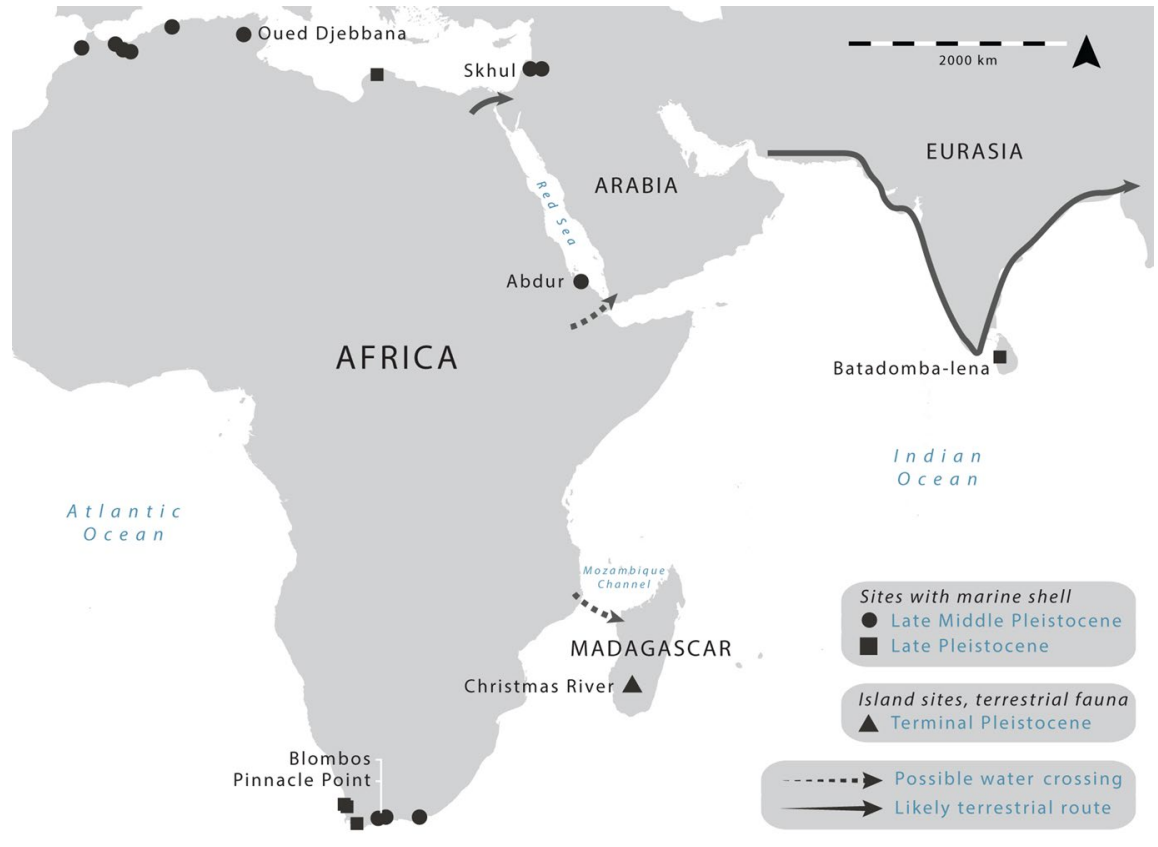

Fig. 5 The Indian Ocean region showing key sites associated with marine resources and major coastal dispersal routes out of Africa

now submerged. As such, Wallacea allows us to think about how different hominins adapted to specific insular biogeographic zones and how these changing environs impacted long-term behavioral trajectories and water-crossing routes (Fig. 6).

$H$. erectus were present around Sunda since the Middle Pleistocene, probably arriving during one or more sea-level low stands, 1.8-1.74 million years ago. The paleoenvironmental record covering the time span of $H$. erectus in Southeast Asia (on Java 1.51 million years ago to 117,000-108,000 years ago, see Hyodo et al. 2011; Rizal et al. 2020) is poorly understood. However, there is growing evidence for occupation along lakeshores and in marshy areas within broader mosaic grassland and forest landscapes, particularly later in the record (Rabett 2017). Specifically, the Trinil and Sangiran H. erectus had access to near-coastal rivers, swamp forests, lagoons, lakes, and marshes with minor marine influences (Bettis et al. 2009). In these environments a wide array of easily caught near-shore fish species were present, and accumulations of Pseudodon and Elongaria shell may indicate predation by $H$. erectus (Joordens et al. 2009). Moreover, during times of insularization and increased precipitation (which typified MIS-60, MIS-40, MIS-22, MIS-12, and MIS-6), highly mobile hominins may have found themselves increasingly entering novel environments, even when revisiting known resource patches, with selective pressures favoring groups who proved adaptively flexible. Such environmental variation could have promoted expansions toward the coast to make use of littoral resources. This is supported by findings at both Sangiran and Trinil that suggest $H$. erectus were using shell tools and engraving shell by about 500,000 years ago (Choi 
and Driwantoro 2007; Joordens et al. 2015). Along with implications for incipient aquatic adaptation, this has important ramifications for the symbolic and cognitive dimensions of Southeast Asian H. erectus.

As Rabett (2017) points out, it could be this ecological diversity that led to the long survival of these hominins. I would add that it might have also encouraged adaptive flexibility in new environments. This flexibility perhaps led to $H$. erectus making the first open water crossings in history and adapting to islands. Early and Middle Pleistocene hominins crossed water gaps of at least 20-40 km to reach three islands: Flores, Luzon, and Sulawesi. The earliest known crossings reached Flores in the Lesser Sunda Chain, with evidence for island occupation 1 million years ago at Wolo Sege (Brumm et al. 2010) and 880,000 years ago at the Mata Menge site (Morwood et al. 1998). It is likely that these hominins-H. erectus or an unknown species-moved west to east across several straits into Sumbawa and then Flores, or north to south through Sulawesi (Bellwood 2017, p. 35).

Dennell et al. (2014) argue that this dispersal onto Flores followed the latter route via Sulawesi (or perhaps the Sunda mainland around modern Borneo), passively following strong southerly currents. If this were true, we might also expect to see hominins on Sumba Island, just south of Flores, but as yet there is no evidence for this (Turvey et al. 2017). These islands would have been even larger targets with much shorter crossing distances during the Pleistocene (Kealy et al. 2017). Bellwood (2017) suggests a move from Sulawesi did not require a single catastrophic passive dispersal but a series of small 10-20 km jumps from Sulawesi to Salayar and small reef islands including Taka Bone Rate along with now submerged paleoislands, followed by a single larger crossing of around $85 \mathrm{~km}$ to reach Flores. As Morwood (2014, p. 112) notes, even if these hominins passively dispersed to Flores through inclement weather events, it is likely that they were doing things around the coast, for instance, exploiting near-shore resources with natural rafts that increased their chances of being swept out to sea.

Whatever arrived on Flores evolved into the small-bodied, small-brained hominin Homo floresiensis, with type fossils discovered at Liang Bua (Fig. 7; Brown et al. 2004; Morwood et al. 2004). These hominins occupied the island until 60,000 or possibly 50,000 years ago (see Table 1; Sutikna et al. 2016), and despite intense initial debate as to whether they represented a diminutive or pathological form of H. sapiens (Argue et al. 2006; Henneberg et al. 2014; Martin et al. 2006), consensus now points to $H$. floresiensis being a separate morpho-species (Aiello 2010). Recent fossil evidence excavated from Mata Menge, dating to about 700,000 years ago, shows that the ancestors to the Liang Bua H. floresiensis were even smaller in stature (Brumm et al. 2016; van den Bergh et al. 2016b), suggesting they very rapidly dwarfed on Flores or that they existed in a diminutive form prior to arriving on the island, perhaps in Sulawesi. Ultimately, it is unclear if these small-bodied hominins derived from $H$. erectus as most researchers have previously suggested, or an as yet unidentified hominin representing an extremely early pulse out of Africa, given strong morphological similarities with Homo habilis (Argue et al. 2017).

The zooarchaeological assemblage at Liang Bua shows remarkable change through time, with Unit IB (120,000-60,000 years ago), which contains H. floresiensis, being dominated by terrestrial faunas (Table S1). Aquatic invertebrates and fish 
Fig. 6 Southeast Asia, showing relative sea level during major marine transgressions: a) $120 \mathrm{~m}$ below present-day sea level. Sea levels would have been this low during several glacial periods including MIS6, MIS-12, and MIS-2 (LGM). Locations of a possible savannah corridor through Sunda and the coastal corridor along Sumatra and Java are indicated; b) $50 \mathrm{~m}$ below present-day sea level. This is approximately representative of 65,000 years ago (see Kealy et al. 2017), when $H$. sapiens may have been entering Wallacea for the first time. Hypothetical dispersals are indicated, following Birdsell's northern and southern routes (1977), Morwood and Van Oosterzee (2007), Sondaar (1989), and Kealy et al. (2018); c) present-day sea level. Major biogeographic transitions are marked, including the Wallace, Huxley, Weber, Lydekker, and Zollinger Lines. For color legend please refer to online version of the article

make up only $0.23 \%$ of the assemblage. This contrasts to later Neolithic H. sapiens levels (Unit 8A-C), which contains $13 \%$ aquatic invertebrates, perhaps brought to the site as adornments and tools. Although taphonomic studies are required to confirm that these changes are behaviorally induced, it tentatively suggests the utilization of shellfish by recent populations was not mirrored in H. floresiensis or Pleistocene $H$. sapiens, who are first detectable in a shift to lithic raw material selection at c. 46,000 years ago (Sutikna et al 2018). This is important because it shows that variable subsistence and technological strategies were successful on Flores and that long-term behavioral trajectories seem to have informed similar adaptations among multiple species in the same environment.

Middle Pleistocene hominins also made crossings into the Philippines, which would have formed several larger landmasses separated from Sunda by the Luzon and Mindoro Straits. At the Kalinga site in Luzon's Cagayan Valley, Rhinoceros philippinensis remains with clear evidence of butchery in association with 57 lithics were found in bone beds dated to 777,000-631,000 years ago (Ingicco et al. 2018). No hominin remains were found during excavations, but the results suggest that $H$. erectus or an unknown hominin species crossed to the Philippines during a sea-level low stand in MIS-20 or earlier. Support for these finds comes from the Arubo open sites in central Luzon, where bifacial handaxes and horsehoof cores resemble the Pajitanian industry of H. erectus in Java (Pawlik 2004), and from the Haluga open sites on Mindanao, which contain large choppers and picks (Tiauzon et al. in press).

At Callao Cave in northern Luzon, a metatarsal was dated using U-series to sometime before 67,000 years ago (Mijares et al. 2010). Recently, the recovery of additional remains, including teeth and postcranial elements, has led researchers to suggest they derive from a previously unrecognized species: Homo luzonensis (Détroit et al. 2019), which was short in stature and shares morphological characteristics with $H$. floresiensis, $H$. erectus, $H$. sapiens, and the australopiths. Although no lithics were found in association with the bones, many of the cervid remains from the same deposit display cutmarks, akin to that produced with bamboo knives (Manalo 2011).

It is likely that there was substantial morphological variability among hominins living in the insular tropics, mimicking what we see in non-Homo primate species (Foley 1991). However, the Callao remains pose an important question: how do we confidently define new species with limited skeletal evidence? Do the finds convincingly indicate allopatric speciation following water-crossing events, or a distinct subgrouping within a broader population of small-bodied Wallacean 
a

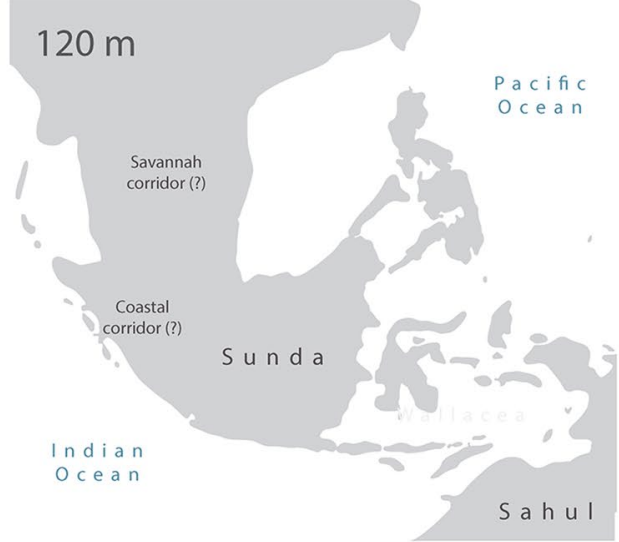

b

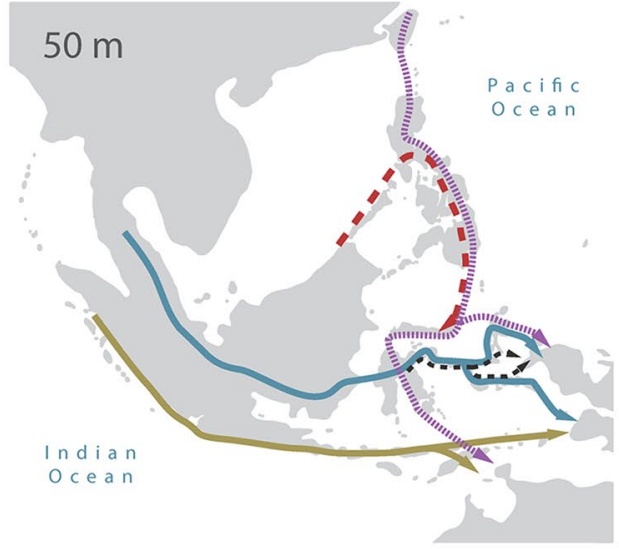

c $\quad 0 \mathrm{~m}$

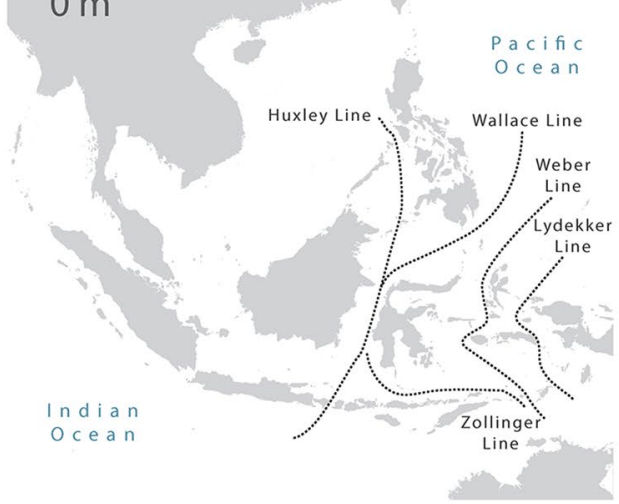

$\longrightarrow$ Birdsell Southern Route $\rightarrow$ Birdsell Northern Route $\rightarrow$ Sondaar Route Kealey \& Colleagues Route $\rightarrow$ Moorwood \& Van Oosterzee 


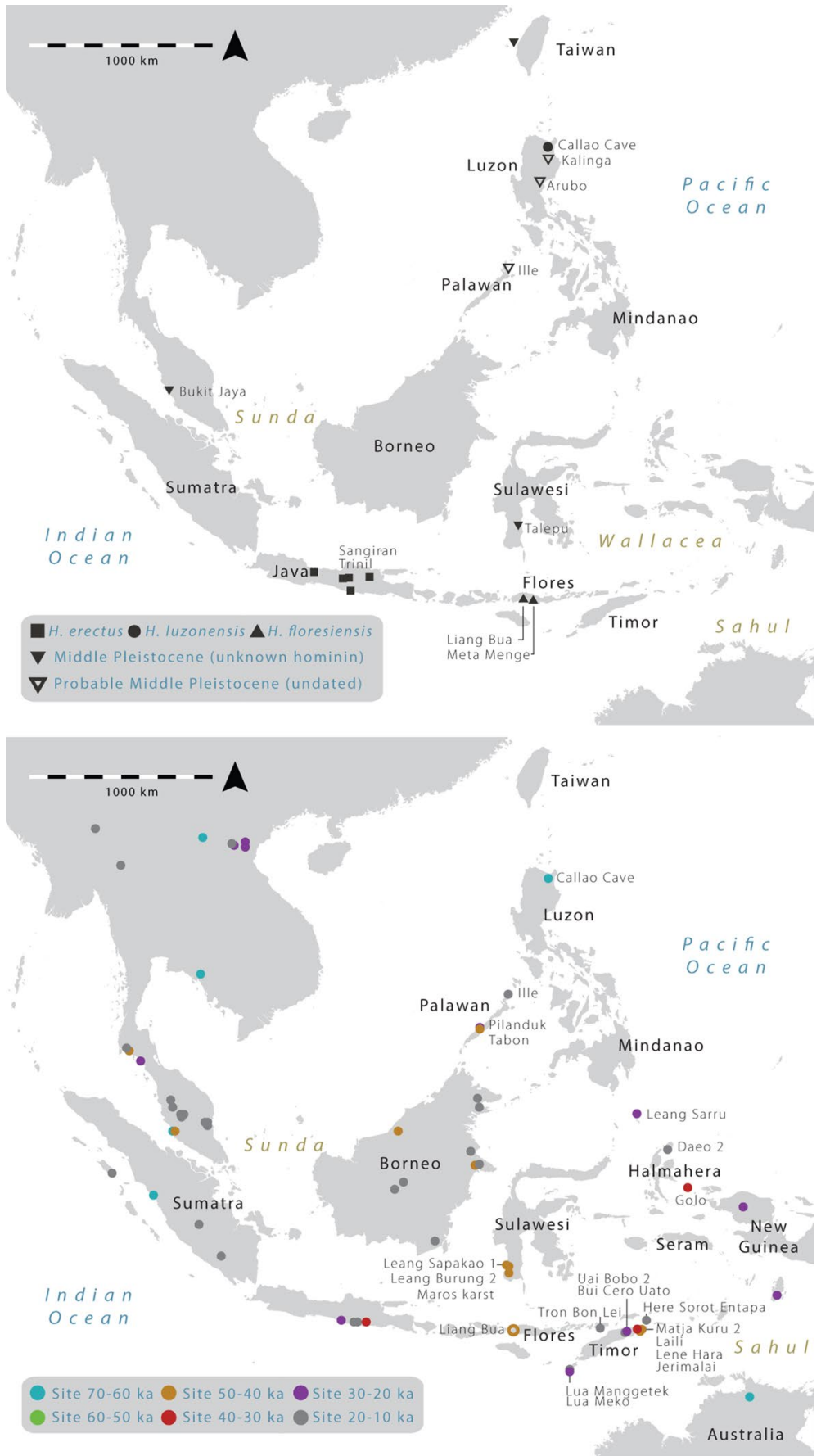

Fig. 7 Above: known archaeological sites in Island Southeast Asia relating to Early and Middle Pleistocene water crossings, including $H$. erectus, H. floresiensis, H. luzonensis, and unknown Homo species; below: archaeological sites relating to the movement of $H$. sapiens into Wallacea. For color legend please refer to online version of the article 
hominins, given the notable decoupling of morphological and molecular genetic variability within the genus (Curnoe 2003).

Thirdly, there was a dispersal of unknown hominins into Sulawesi by the end of the Middle Pleistocene at least 200,000 years ago and possibly up to 780,000 years ago (van den Bergh et al. 2016a). Sulawesi was always separated from Sunda by short water crossings (Table 2), but it is not known if these populations spread eastward from what is now Borneo or from the north through the Philippines. The string of islands north of the northern arm of Sulawesi probably facilitated water crossings between Wallacea and the Philippines, along with routes from Sunda through Palawan, and across the Tapiantana Channel and Basilan Strait via the Sulu Archipelago. At Telepu in the Walanae Basin in southwest Sulawesi, hominins discarded 311 stone artifacts in association with megafaunal remains of bovids, stegodons, and suids. The lithics are expedient and show a preference for sharp edges over formal morphology (van den Bergh et al. 2016a), something that is shared among all hominins in the region, along with modern ethnographic toolmakers (White and Thomas 1972), and suggests convergent adaptations within similar ecological spaces. This may relate to the presence of other organic materials that can better facilitate specific tasks such as butchery and plant processing. It also may indicate that, with high levels of mobility and an abundance of raw materials, hominins were able to rapidly find and exploit high-quality lithics and so did not practice lithic conservation for risk reduction as they did not anticipate moving into areas poor in lithics.

The first record of $H$. sapiens in the region occurs several millennia after these initial dispersals. In Sunda, there is substantial evidence for $H$. sapiens at Song Terus and Tabuhan Cave in eastern Java by 45,000 years ago (Sémah and Sémah 2013, 2013) and 60,000-70,000 years ago (Westaway et al. 2017), or more debatably by $<128,000->118,000$ years ago (Westaway et al. 2007). It is unclear if the $H$. sapiens dispersing into Sunda were already adept sea-goers who entered coastally via the southern dispersal route, suggestive of gradual modification (Fig. 6a), or via a savannah corridor bordered by coastal rainforests (Heaney 1991), leading to a major biogeographic leap when the species entered Wallacea for the first time, suggestive of rapid flexibility (see Fig. 6a).

The route into Sahul has also long been debated (Fig. 6b), especially whether H. sapiens took Birdsell's northern route through Sulawesi and Maluku, eventually arriving in today's Raja Ampat Islands and the Bird's Head of New Guinea, or Birdsell's southern route, through Timor and into Kimberly country in northwest Australia (Fig. 6b; Birdsell 1977). Although some dispute pre-55,000 dates (O'Connell et al. 2018), there is increasing acceptance of a pre-60,000 date for the arrival of $H$. sapiens in Sahul (Clarkson et al. 2017).

Recent modeling studies using up-to-date bathymetry are at odds. Kealy et al. (2018) suggest that a northern route into Sahul, through a number of short water crossings, is most likely (see also O'Connell and Allen 2012), although there is a lack of recent research along the northern route. In contrast, Norman et al. (2018) assert that a pre-LGM low stand occurred 60,000-70,000 years ago, in line with the earliest secure dates from northwest Sahul at Madjedbebe in northwest Australia 
(Clarkson et al. 2017), supporting a more easily achieved southerly route, or at least a dual route.

Evidence for Birdsell's southern route comes primarily from Timor. At Laili on East Timor, preserving perhaps the earliest direct evidence of $H$. sapiens in Wallacea at 44,600 years ago, hunters and gatherers exploited local cherts to produce expedient flakes, with minimal evidence for raw material conservation, and targeted a wide array of terrestrial and marine animals (Hawkins et al. 2017b). At Lene Hara, a transit camp between the coast and inland (O'Connor et al. 2002), similar flakes and marine shell date to 42,000 years ago (O'Connor et al. 2010a). Symbolic behavior in the form of anthropomorphic petroglyphs and painted faces at the caves dates maximally to c. 37,000 years ago and continued into the Terminal Pleistocene (Aubert et al. 2007; O'Connor et al, 2010b).

Also on Timor, the earliest known occupants of Asitau Kuru (formerly Jeremalai) primarily relied on marine foods (Roberts et al. 2020) and may have been capable of catching a diverse variety of pelagic fish species, along with littoral resources by 42,000 years ago (O'Connor 2015). About one-third of the initial Pleistocene fish assemblage is made up of scombrids, which are known to be fast swimming and hard-to-catch deep-water species, perhaps caught with boat technology (although see critiques from Anderson 2013, who suggests the fish could have been collected near the shore). In support of O'Connor (2015), there is later evidence for line fishing in a Trochus shell bait hook dated to 16,000-23,000 years ago. Interestingly, in the mid-Holocene layers, inshore fishing increased while pelagic fishing decreased, suggesting that maritime mobility actually decreased after initial settlement (O'Connor et al. 2011b), in line with the establishment stage of adaptive flexibility.

Asitau Kuru also contains shell tools that were modified by drilling, pressure flaking, and grinding and Nautilus shells with pigment staining that were used to process ochre 42,000-38,000 years ago, perhaps indicative of personal adornment and ceremonial behaviors (Langley et al. 2016). Additional evidence is present at Tron Bon Lei rockshelter on Alor Island, where circular rotating fishhooks were found as grave goods in an adult female burial from the Terminal Pleistocene, c. 12,000 years ago (O'Connor et al. 2017b).

Obsidian characterization studies from Tron Bon Lei show that stones were imported from at least three different sources around the Sunda Arc, with maritime exchange between Alor and Timor beginning in the Terminal Pleistocene (Reepmeyer et al. 2016). This obsidian exchange, fostering ongoing inter-island support and intermarriage, may have facilitated the initial peopling of even the tiniest of Wallacean islands. One such island was Kisar, where Here Sorot Entapa rockshelter, dating to c. 15,500 years ago, was probably used as a fishing camp where people produced and discarded one-piece fishhooks, caught a variety of fish and turtle species, collected shellfish, and hunted for locally available bats (O'Connor et al. 2018).

Although computer modeling indicates the shortest achievable water crossings existed along Birdsell's northern route (Kealy et al. 2018), there is sparse archaeological evidence, which mostly postdates the early sites on Timor. Rock art from several cave sites in the Maros Karst area of Sulawesi, dated by U-series to at least c. 40,000 years ago, suggests $H$. sapiens were present on the island by that time (Aubert et al. 2014, 2019). This represents both the oldest directly dated hand 
stencils in the world and the earliest evidence of figurative art. Lithics from these areas have previously been dated to 30,000-19,000 years ago (Bulbeck et al. 2004; Glover 1981). Slightly earlier rock art from the east coast of Borneo, at the edge of Sunda, dates to 40,000-52,000 years ago (Aubert et al. 2018), perhaps representing directly ancestral groups to those along the northern route of Wallacea.

Farther east, at Golo cave on Gebe Island, between Halmahera and New Guinea, there is evidence for shell tool production by 35,000-30,000 years ago and an emphasis on marine subsistence (Szabó et al. 2007). However, lithic artifacts from Golo and nearby Wetef cave dated to 25,000 years ago were produced by smashing cobbles on an anvil and are highly amorphous, with stronger affinities to northern Sahul assemblages than to those from Sulawesi (Tanudirjo 2001, p. 335). These similarities in stone flaking led Tanudirjo (2001, p. 401) to suggest the area may have been occupied first from Sahul, rather than from the northern route. This scenario has not been widely addressed in recent literature (except peripherally by Kealy et al. 2017), but it is worth revisiting. Ongoing research by several field teams in Seram, northern Maluku, and the Raja Ampat Islands should help clarify this.

At Daeo 2 and Tanjung Pinang on nearby Morotai Island, occupation began after the LGM 16,000 years ago, with evidence for more intensive occupation than on Gebe. Pebble tools, bone points, unretouched flakes, canarium nut anvils, manuports, cooking stones, and ochre are all present, and subsistence strategies involved the collecting of marine shellfish and landsnails and the hunting of rats and cuscus (Tanudirjo 2001, p. 402).

The Talaud Island group between northern Sulawesi and the Philippines was occupied by 30,000 years ago, representing inter-island crossings of over $100 \mathrm{~km}$ and a possible southerly corridor into Wallacea from the Philippines (Ono et al. 2015). At Leang Sarru on Salibabu Island in the Talaud group, shell data indicate a change to coastal resource use through the LGM and Terminal Pleistocene when seawater temperatures increased. As on Kisar Island, terrestrial resources were depauperate, and marine resources played a major role in the diet.

H. sapiens also island-hopped into the Philippines, first into Palawan and then across the Mindoro Strait into Luzon (Mijares 2015). This required crossing Huxley's Line (Fig. 6c), a major biogeographic divide that separates continental Sundaland faunas from an eclectic mix of insular animals. There is direct evidence of our species at Tabon Cave on Palawan, including crania and mandibles dating to 16,500 years ago and a tibia and mandible dating to 47,000-30,000 years ago (Détroit et al. 2004; Dizon 2003; Dizon et al. 2002). The Tabon lithic sequence resembles that from Callao 28,000 years ago (Mijares 2006), which implies the earliest representatives of our species learned common manufacturing techniques. In both industries, a variety of hard hammer flakes were made from siliceous cherts, including some elongate flakes, while blades were not systematically made from these materials (Fox 1970; Mijares 2007). Most of the lithics were applied to hard materials and exhibited a silica gloss with minimal retouch (Xhauflair and Pawlik 2010).

The "bamboo hypothesis" is that these assemblages are technologically simple because they were used to produce composite organic tools from bamboo (Brumm 2010). Usewear and residue studies from the island group confirm that many lithics were used in processing bamboo or possibly other silica-rich plants such as palms 
and grasses (Xhauflair et al. 2016); ethnoarchaeological studies from Palawan indicate that a huge variety of local plants can be used for technological purposes as well as for medicine and ornaments (Xhauflair et al. 2017), demonstrating sophisticated adaptations to rainforest resources.

There seem to have been shared adaptations on the small islands of Wallacea and the Philippines during the Late Pleistocene, including high mobility, the production of expedient tools with some platform preparation, a reliance on marine and coastal subsistence alongside hunting small but reliable game, developments in fishing technology, and early evidence for visually symbolic and ceremonial behaviors. There was a lack of both lithic provisioning and evidence for inter-island exchange until after the LGM.

\section{The First Pacific Islanders}

The possibility that multiple hominin species crossed into northern Sahul and the Pacific has, so far, been overlooked. However, genetic research reveals that the highest frequency of Denisovan admixture with $H$. sapiens occurred among the ancestors of Australian Aboriginals and New Guineans, leading Cooper and Stringer (2013) to ponder whether these hominins also crossed into Near Oceania. Jacobs et al. (2019) speculate there was introgression from one lineage of Denisovans east of the Wallace Line, which continued into the Terminal Pleistocene. The archaeological and paleoanthropological evidence, however, is nonexistent.

With the crossing to continental Sahul, the biogeographic constraints of living on islands were suddenly lifted, and there is substantial evidence that intrepid humans made extensive use of a wide range of challenging environments such as rainforests, arid zones, and mountains. However, coastal and island adaptations continued to facilitate part of the rapid dispersal of $H$. sapiens along the coast of northern Sahul and beyond (Allen 2000; Bowdler 1990). Although the move into Sahul, and again into the Bismarck Archipelago, would have presented variable floral and faunal diversity, the Malesian and Papuasian regions (New Guinea, Indonesia, Malaysia, and the Philippines) share enough similarities in resources (Paijmans 1976) that technological and subsistence practices could be maintained or gradually modified during the initial phase of movement through relatively similar latitudes (see Florin et al. 2020). Even throughout MIS-3 and MIS-2, climatic conditions around the coast and on low-lying islands would have been relatively consistent and similar to today (Farrera et al. 1999, p. 841). The broader coastal environment was dominated by lowland equatorial rainforests and some savannah, while gradually rising and lowering sea levels produced swamps of brackish water, estuaries, and coral reefs rich in littoral resources (Chappell 1993; Swadling and Hope 1992).

During the first 30,000 years of human activity, occupation was small scale, and the impact on faunal and floral resources seems to have been low (Summerhayes 2007). Between Wallacea and the Bismarcks, a number of Late Pleistocene sites such as Toe, Lachitu, and Wantiglo (Fig. 8) reflect the movement of people along northern Sahul, who made forays into the interior to hunt small game and probably 


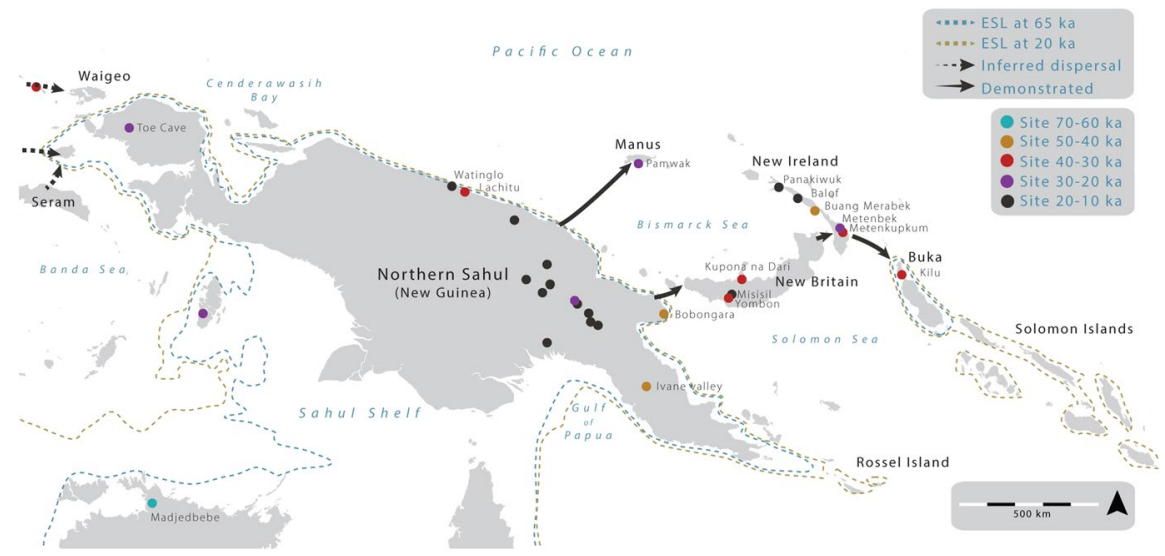

Fig. 8 The western Pacific islands and northern Sahul region, showing known Pleistocene sites and routes of water crossings. The Sahul coastline at c. 65,000 years ago and at the LGM are marked based on Kealy et al. (2018) and sahultime.com. For color legend please refer to online version of the article

megafauna and to collect highland resources such as Pandanus (Gorecki et al 1991; O’Connor et al. 2011a; Pasveer 2004).

At Bobongara Hill, formed of massive uplifted terraces in northeast New Guinea (Groube et al. 1986), numerous "waisted" stone tools dating to $\sim 40,000$ years ago may have been hafted and used for ring barking and root clearance for forest management (Groube 1989). The first water crossings into the Bismarck Archipelago were probably made from this area. This journey relied on relatively sophisticated seafaring abilities, requiring, minimally, one crossing of $40 \mathrm{~km}$ across the Vitiaz Strait and another of $25 \mathrm{~km}$ across the Dampier Strait (Summerhayes et al. 2017). These straits can be treacherous at certain times of year, and so established knowledge for predicting and understanding weather patterns would have been essential. Surface finds of robust waisted tools along a $1.8 \mathrm{~km}$ stretch of coast on Rossel Island (Shaw 2017) provides further evidence for early seafaring from the tip of southeastern Papua into the Massim region. Although the tools remain undated, the size and nature of flaking is suggestive of Late Pleistocene lithic traditions on the Sahul mainland. The small size of Rossel, even during the LGM, indicates that humans continued to frequent small offshore islands in the Pacific as they did in Wallacea.

In the Bismarcks, occupation at Kupona na Dari, on the Willaumez Peninsula of New Britain, dates to 45,000-35,000 years ago (Bonetti et al. 1998; Torrence et al. 2004). Geochemical analyses of obsidian artifacts at the site reveal the import of lithic material from long distances, including local Baki and Gulu material from the peninsula itself and obsidian from the Mopir source in the rainforested interior of New Britain (Torrence 2004). During this time, the landscape would have been exposed to a series of major volcanic events (Neall et al. 2008), but the archaeological sequences suggest humans only temporarily abandoned the area, engaging flexible and mobile settlement strategies, with a strong social memory that allowed them to resettle former habitation sites (Torrence 2016). 
Yombon in the interior of New Britain, dating to 35,000 years ago, provides further evidence for human occupation in insular rainforests (Pavlides and Gosden 1994). Paleoenvironmental records suggest anthropogenic forest burning was deliberately used to open gaps for hunting; however, no faunal remains exist to test this (Lentfer et al. 2010). The material from Yombon is almost exclusively local chert that was flaked in an expedient manner characteristic of early northern Sahul assemblages. These data have two broad implications for human adaptation: the first islanders did not simply hug the coast but ventured into unexplored dense rainforest (for supporting evidence from the mainland of Sahul, see Summerhayes et al. 2010), and they were doing this systematically enough to come across good-quality lithic deposits in the forest. The absence of obsidian at Yombon may relate to the difficulty of accessing the resource at the time, or simply because these flows did not exist yet (see Bonetti et al. 1998). Misissil, a cave close to Yombon, was first occupied in the Terminal Pleistocene, 13,000 years ago (Pavlides 2004; Specht et al. 1981). Obsidian was present while local chert was less common, showing that by this point people had exploited and redistributed higher-quality obsidian around the island.

Getting from New Britain to New Ireland required additional water crossings through the dangerous currents of the St. Georges Channel (Summerhayes and Allen 1993). At Buang Merabek on the east coast of New Ireland, occupation stretches back 45,000-43,000 years (Leavesley and Allen 1998), while Matenkupkum dates to about 41,000-30,000 years ago (Allen et al. 1988). The faunal records for the initial period of settlement indicates the caves were used as nonintensive stopover camps by mobile hunter-gatherers, ranging both inland and around the caves for bats and reptiles and on the coast for shellfish and fish (Leavesley 2004; Smith and Allen 1999). In an environment without large, high-rank game such as megafauna on the Sahul mainland, predictable terrestrial resources such as large quantities of fruitbats would have been invaluable. This reflects a tendency for early seafarers to return to reliable resource patches in novel environments. There is also evidence for shark hunting at Buang Merabek, where a drilled shark tooth ornament may have had ritual or prestige connotations (Leavesley 2007).

As Wallacean and Pacific food sources such as plants, mollusks, and arboreal mammals were relatively sedentary, their local depletion would necessitate frequent relocation. In response, a focus on boat technology for residential mobility would reduce stress on the elderly, pregnant women and children (Torrence 2012). Maritime activities such as inshore and possibly offshore fishing can then be seen as byproducts of this movement through the islands; evidence for this on New Ireland includes shell fishhooks dating to 18,000-20,000 years ago (Smith and Allen 1999).

Later in the Pleistocene, during MIS-2, occupation at Matenbek on New Ireland began 24,000-23,000 years ago (Allen et al. 1989). Mopir obsidian was present from the earliest occupation and indicates the deliberate and repeated transport of high-quality flaking material over $350 \mathrm{~km}$, as the crow flies (Summerhayes and Allen 1993). This demonstrates provisioning strategies and prior resource knowledge. It may also represent exchange across social boundaries; Summerhayes and Allen (1993) argue that semi-sedentary populations practiced down-the-line exchange to distribute this material. In support, the Matenbek midden contains reef fish and shellfish, but cuscus (Phalanger orientalis) bones in the 
initial layers provide the earliest global evidence for animal translocations across bodies of water (Summerhayes et al. 2017). These animals were absent from preLGM layers at Buang Merabek and Metenkupkum, but there was a boom in hunting these arboreal mammals following the LGM (Flannery and White 1991).

Residue analysis from the Balof site shows that wild taro and yams also were processed during the Terminal Pleistocene (Barton and White 1993). At Panikiwuk, farther north, occupation began in the LGM c. 18,000 years ago (Marshall and Allen 1991); however, in contrast to earlier sites, the diet was terrestrial, with a sparse fish assemblage suggestive of reduced reliance on coastal and marine resources.

Human occupation on Manus Island provides definite evidence for water crossings that required seafarers to move out of sight of land. This signals a major shift in technological abilities, especially involving techniques of environmental navigation and wayfinding, and suggests that the voyagers were highly confident, even by today's standards. At Pamwak, dated to c. 21,000 years ago (Spriggs 2001) and probably accessible following a river $10 \mathrm{~km}$ inland (Frederickson et al. 1993), the majority of occupation occurred during the LGM and in the Terminal Pleistocene. Obsidian was collected locally from the Admiralty sources by 14,000 years ago (Frederickson 1997), while cuscus (Spilocuscus kraemeri), bandicoot (Echymipera kalubu), and canarium nuts represent separate translocations from mainland Sahul, $230 \mathrm{~km}$ away (Kennedy 2002).

From northeast New Britain or southeast New Ireland, it would have required a series of island hops of about $60 \mathrm{~km}$ through the Feni Islands and the Green Islands to reach the northern Solomons. Kilu cave, first occupied c. 33,000 years ago, is the only known Pleistocene site in the Solomon Island chain, which would have formed one larger island during eustatically lowered sea levels. As at many other island sites in the Pacific, people hunted bats and other terrestrial fauna, collected shellfish, and caught fish (Wickler 2001, pp. 218-220). The fish assemblage may indicate similar deep-water fishing strategies as evidenced in Wallacea at a similar time, and crucial stone-tool residues indicate people were processing wild root vegetables such as taro (Colocasia and Alocasia) by 29,000 years ago (Loy et al. 1992).

After Kilu was first occupied, the material evidence, including the absence of imported obsidian and a dearth of marsupial translocations, suggests that contact with the Bismarcks ceased (Wickler and Spriggs 1988). The Solomons were likely occupied more widely during the Pleistocene, but due to raised sea levels and a lack of uplifted coastal zones (such as on the north coast of New Guinea), attempts to locate similar occupation have failed. The next oldest site is Vatuluma Posovi, with initial occupation beginning in the Early-Mid Holocene (Roe 1993). People did not make the next push into Remote Oceania, crossing the threshold of $300 \mathrm{~km}$ voyages, until after 3,000 years ago, and into eastern Polynesia later still (Wilmshurst et al. 2011).

In the Pleistocene Pacific we see a continuation of the behavioral trajectories observed in Wallacea and the Philippines, with H. sapiens making use of large continental islands and very small landmasses with high marine ecodiversity and depauperate terrestrial resources. In these places, people collected extensively from the littoral and possibly pelagic zone, translocated animals to improve terrestrial protein 
availability, and redistributed high-quality lithic material across water gaps. We also see humans pushing the boundaries of these trajectories and expanding into islands that were completely out of relative and absolute inter-visibility, which would have required meticulously planned, multiday voyages through high-risk seas.

\section{Insular East Asia}

Similar evidence demonstrates that hominins expanded into the continental and oceanic islands off the coast of eastern Eurasia (Fig. 9). It is currently debated whether non-sapiens occupied the Japanese islands; however, from what we know about Wallacea it would not be impossible. Matsufuji (2011) makes the case that

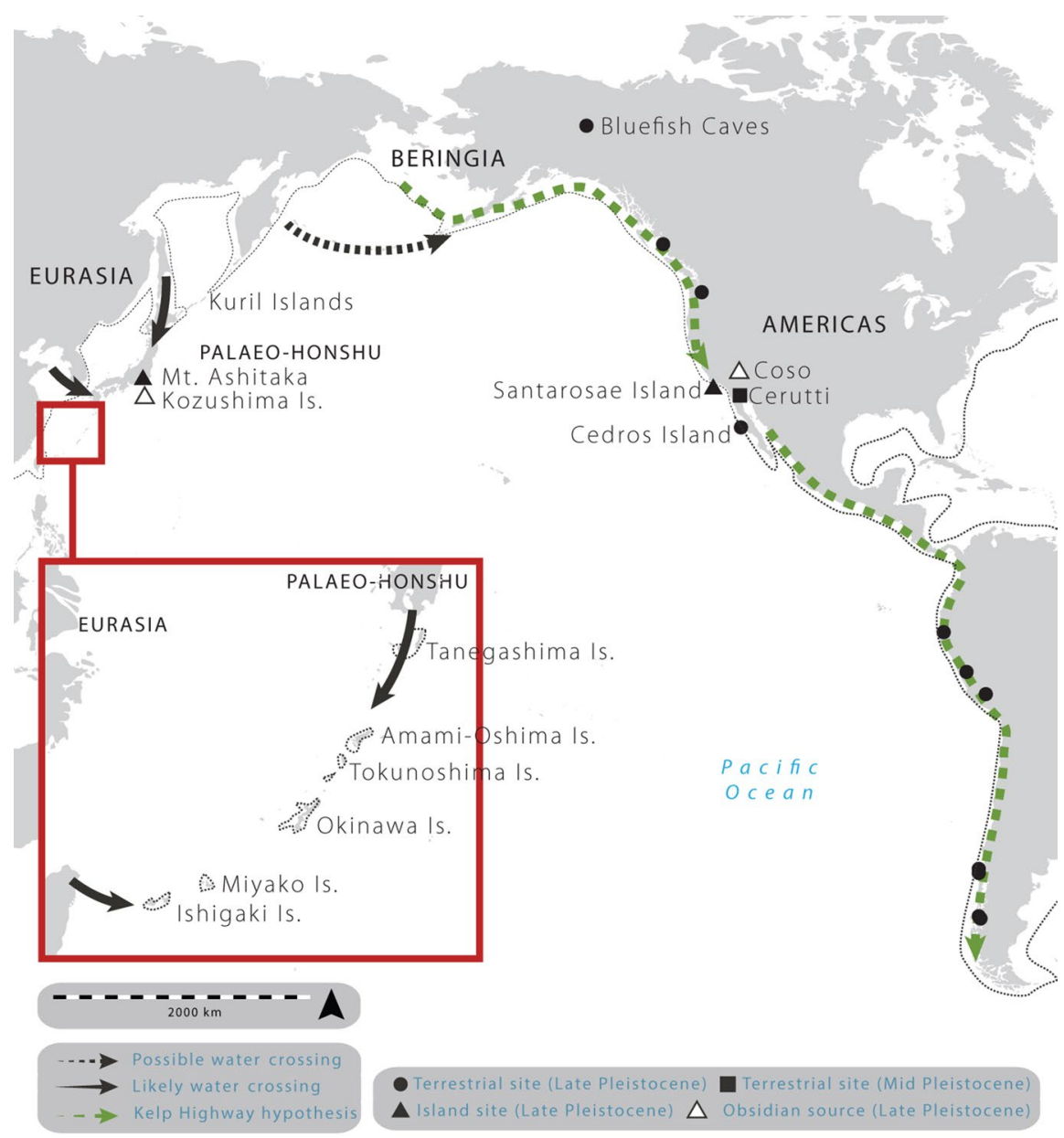

Fig. 9 Eastern Eurasia and the Americas showing major water crossings into Paleo-Honshu, the Ryukyu Islands, and the California Channel Islands, along with likely coastal dispersals through the Americas 
Middle Pleistocene hominins entered Japan by MIS-6, a glacial period when sea levels were lowered. Possible lithic artifacts from Kanedori are associated with tephra dated to 115,000-84,000 years ago; however, Norton et al. (2010) question whether these remains are indeed artifactual and stress current evidence that $H$. sapiens first entered the Japanese islands in MIS-3. At that time, the northern island of Hokkaido was connected to Sakhalin and the northeast Eurasian mainland as a peninsula, due to lowered sea levels. Honshu, Shikoku, and Kyushu, on the other hand, formed one larger island called Paleo-Honshu, which was separated from Eurasia by the Tsugaru Strait to the north, the Korea Strait to the west, and the Tokara Strait to the south.

There is substantial evidence for $H$. sapiens crossing one or more of these straits, with over 500 Early Upper Paleolithic sites recorded on Paleo-Honshu, mainly located around river terraces and open-air foothills (Izuho and Kaifu 2015). These sites emerged between 38,000 and 30,000 years ago and are associated with standardized lithic tools and long-distance raw material transport. During initial occupation, the island was characterized by a variety of temperate forests (Takahara and Hayashi 2015), while tropical broadleaf forests were limited to southern Paleo-Honshu (Iwase et al 2015). There was also a focus on hunting large terrestrial game and evidence for complex strategizing in the form of pit traps (Sato 2012). However, impacts on megafauna seem to have been relatively small for many millennia (Iwase et al. 2015), which may be in line with evidence from Madagascar and Sahul. On Paleo-Honshu the Paleoloxodon-Sinomegaceroides megafaunal complex included Naumann's elephant, Yabe's giant deer, Sika deer, brown bears, martens, least weasels, Eurasian badgers, racoon dogs, monkeys, wolves, and foxes. These became extinct during the LGM or at the Terminal Pleistocene (Iwase et al. 2012), indicating that climatic and vegetational changes, rather than sudden human overhunting, were key factors in their extinction.

Lithics that were made on this large island using good-quality cryptocrystalline materials such as obsidians, sanukite, and hard shale include trapezoids, pointed backed blades (also known as knife-shaped tools), and edge-ground axes (Iwase et al. 2015). There seems to have been island-wide technological changes through the Pleistocene, which indicates strong levels of interaction and mobility between Japan and mainland Eurasia. Several artifact types such as the Hakuhen-Sentoki points common around Kyushu (central Paleo-Honshu) and the Korean Peninsula suggest ongoing interaction (whether group or individual movements) across the strait in the Upper Paleolithic (Chang 2013). Morisaki (2015) interprets this as evidence for a second small-scale human migration into Paleo-Honshu through the Korean Strait, following the Aira-Tn eruption c. 30,000 years ago.

Further evidence for more strategic episodes of seafaring comes from the procurement and transport of stone raw material from islands $40-45 \mathrm{~km}$ offshore, as early as 38,000 years ago. Geochemical studies demonstrate that obsidian artifacts were obtained from Kozushima (a small island in the Pacific Ocean), transported along the Izu Island chain to Paleo-Honshu, and then discarded at various sites around Mt. Ashitaka (Ikawa-Smith 2008). Ikeya (2015) suggests this may have been achieved through the use of leather-clad boats formed of a lightweight wooden frame made from branches rather than heavier dug-out canoes, which are sometimes found in archaeological sites from the later Jomon period, 
and facilitated by changes to axe technology that would have allowed tree felling and hulling. Importantly, the earliest dated sites around Mt. Ashitaka contain abundant Kozushima obsidian, but later sites during the LGM and the Terminal Pleistocene contain much reduced quantities until the Jomon period in the Early Holocene (Tsutsumi 2010). This implies there was initially high maritime mobility, exploration, landscape learning, and resource exploitation, followed by a turn inland, perhaps related to the gradual focus on Paleo-Honshu stone resources and the Paleoloxodon-Sinomegaceroides megafaunal complex.

To the south, the offshore Ryukyu Islands preserve evidence for long-distance voyaging of a similar magnitude required to reach Talaud, the Solomons, and Manus (Kaifu et al. 2015). A substantial number of cave and rockshelter sites in karstic formations indicate that the entire island chain was colonized by MIS3 , and as early as 36,000 years ago. These movements were less extensive than later Holocene settlement efforts such as the Neolithic dispersal into Taiwan from Fujian, but they probably required large founding groups or a period of back-andforth interaction to establish viable populations on the islands.

Kaifu et al. (2015) hypothesize that the initial settlement of the Ryukyus involved multiple migrations from different directions. On Ishigaki in the southern Ryukyus, human remains directly date to the LGM 19,000-29,000 years ago (Nakagawa et al. 2010), while similar H. sapiens remains excavated at Yamashitacho Cave I and Minatogawa on Okinawa Island and Shimojibaru Cave on Kume Island in the central Ryukyus also were dated by association with wood charcoal to a similar time period, 15,000-32,000 years ago (Kobayashi et al. 1974; Suzuki and Hanihara 1982). Mitochondrial DNA analysis successfully extracted from five of the Ishigaki individuals suggests a strong connection with haplogroups common in coastal Mainland Southeast Asia and Taiwan (Shinoda and Adachi 2017), and it is probable that these lineages spread into the Ryukyu chain through what is now Taiwan, with the genesis of the M7a haplogroup arising in the southern Ryukyus during the LGM and later spreading into the northern Ryukyus and Paleo-Honshu.

The earliest global evidence for fishhooks comes from Sakitari on Okinawa, dating to c. 20,000-23,000 years ago, along with early shell tools dating to 23,500-25,500 years ago (Fujita et al. 2016). These fishhooks are one piece, made from Trochus shell, and are typologically similar to those from Wallacea and the Pacific. The common innovation of shell technology on small islands with poor lithics shows the flexibility of these maritime people to new environments, translating established forms to new materials (Fujita et al. 2016).

The faunal remains from Sakitari include a variety of freshwater species (crabs and mollusks), along with eels, frogs, marine fish, small birds, deer, and small mammals, which show signs of charring on a fire. Perhaps more importantly, these fauna were being exploited on a seasonal basis, which implies the cave occupants returned to collect marine resources at times of high abundance (Fujita et al. 2016). This indicates that people did not necessarily pass quickly through oceanic islands en route to larger terrestrial sources but adapted to inland, littoral, and marine zones as well. Other sites such as Yamashita-cho I and Minatogawa provided evidence for $H$. sapiens in association with several species of deer along with wild boar (Table S1), 
suggesting a mixed economy focus on island mammals along with the marine environment. Kaifu et al. (2015) argue there was an anthropogenic translocation of wild boar into the Ryukyus from mainland Eurasia or Paleo-Honshu to maintain a supply of mid-sized protein sources.

In terms of lithic technology, the Pleistocene Ryukyuans used edge-ground axes (Takashi 2012), and surface finds in the Yaeyamas of the southern Ryukyus indicate waisted implements that are typologically similar to those found around northern Sahul also were used (Anderson and Summerhayes 2008). These likely represent convergent technological innovations in hafting, as waisted implements do not occur in Wallacea or the divide between Japan and Sahul. In contrast to Wallacea and Sahul, a microblade toolkit also developed in the Ryukyus by 20,000 years ago (Takashi 2012).

These initial dispersals into Paleo-Honshu and Ryukyu required similarly advanced maritime technologies as in Wallacea and the Pacific, and the mariners sometimes voyaged long distances, out of sight of land. This occurred concurrently with settlement of the Bismarcks, the Talaud group, and many of the islands of Wallacea, which demonstrates maritime $H$. sapiens populations were thriving around the insular tropics and subtropics at a time when mainland Eurasian populations were severely reduced (Kuzmin and Keates 2014).

\section{Coastal Highways to the New World}

Understanding the water-crossing behaviors of eastern Eurasian H. sapiens is central to debates about Pleistocene seafaring in the Americas. Early evidence from the Bluefish Caves in the Yukon (Fig. 9) suggests that terrestrially adapted huntergatherers were active in eastern Beringia at least 24,000 years ago (Bourgeon et al. 2017). This area may have fostered a relatively isolated population that then dispersed throughout the Americas following climatic amelioration, involving one or two major human lineages that carried multiple language families (Fagundes et al. 2008).

This dispersal from Beringia to the tail end of the continent was incredibly rapid. Early coastal sites in South America include Quebrada Jaguay, Tacahuay, Santa Julia, and Huentelauquén, all dating to around 13,000 years ago, as well as Monte Verde dating to at least 14,000 and perhaps up to 18,000 years ago (Dillehay et al. 2015). This is supported by genetic evidence for north-south dispersals over a period of about 1500 years (Brandini et al. 2017).

To account for this rapidity, Erlandson proposed the "kelp highway hypothesis": deglaciation of the Pacific Northwest created a coastal dispersal corridor rich in marine and littoral resources, which allowed migration down the western fringe of the continents (Erlandson et al. 2007, 2008; see also Fladmark 1979). This scenario has major implications for understanding $H$. sapiens capacities for water crossings in temperate and subarctic zones and for understanding the dispersal of different lineages across the landscape. Unfortunately, although a handful of sites preserve marine fauna that demonstrate foraging activities along the littoral zone (Dillehay 
et al. 2017), finding evidence for initial coastal and island settlements in this area remains difficult due to postglacial sea-level rise. Some underwater survey has been undertaken on submerged sites off the Californian northern Channel Islands (Watts et al., 2011), but most of the evidence remains inundated.

Three sites in the northern Channel Islands off California's Pacific Coast provide the earliest evidence for Pleistocene seafaring in the Americas. These islands (forming one larger island named Santrosae) were separated from the mainland by at least $10 \mathrm{~km}$ of open water during the LGM, and the evidence indicates that coastally adapted people intensively hunted a number of marine mammal and seabird species and collected locally abundant shellfish by 12,000-11,000 years ago (Erlandson et al 2011; Hofman et al. 2018). These sites are contemporaneous with Clovis and Folsom sites, which are often situated around lakes in the interior, such as the Western Pluvial Lakes Tradition in the far west (Amick 1993).

On Santarosae, there are numerous Channel Island barbed stone points and crescents along with red ochre, bone tools, and manufacturing debris at the CA-SRI$512 \mathrm{~W}$ site, which is interpreted to be a temporary winter hunting camp that facilitated easy access to local birdlife and marine mammals that had become abundant on the island due to a lack of terrestrial predators. Midden remains are dominated by sea birds along with some marine mammal bones and smaller numbers of fish (Erlandson et al. 2011); obsidian from the site has been sourced to a flow in eastern California, suggesting trade links with the interior, or residential mobility stretching over $300 \mathrm{~km}$ to the Coso Volcanic Field and beyond (Gill et al. 2019). At two nearby lithic scatters (CA-SMI-678 and CA-SMI-679) dating to the same period, people produced numerous bifaces, stemmed points, and crescents from local chert outcrops and consumed abundant local marine shellfish and crabs (Erlandson et al. 2011).

Farther south on the arid island of Cedros, formerly connected to the Baja California Peninsula, the Pleistocene occupants hunted marine mammals, sea turtles and birds, collected shellfish and crustaceans, and produced unifacially retouched tools (Des Lauriers 2011). Crucially, oceanic deep-water fish also were caught, probably with hook and line technologies as one-piece shell hooks have been dated to at least 11,300 years ago at the Cerro Pedregoso and Richard's Ridge sites (Des Lauriers et al. 2017). This provides additional strong evidence that boats were being used along America's coasts. It remains unclear if the Cedros Island hooks represent remote technological decent from earlier eastern Eurasian examples or a distinct New World innovation; however, leaf-shaped bifaces at the site and other coastal locations stretching from Japan to South America may signify a pre-Clovis coastal dispersal from Eurasia to America (Erlandson and Braje 2011).

Finally, recent controversial claims that hominins reached the Americas in MIS-5 are still being scrutinized, but they have important implications for global human migration and water-crossing behaviors (Braje et al. 2017). Holen et al. (2017) assert that hammerstones and stone anvils found at the Cerutti site in southern California are associated with mastodon bones, dated by $\mathrm{Th} / \mathrm{U}$ to c. 130,000 years ago. Some of these bones are spirally fractured, perhaps indicating that hominins deliberately broke fresh long bones to extract marrow. These breakage patterns closely resemble experimental breakage from using hafted and unhafted cobble hammers on stone 
anvils. They do not resemble carnivore breakage, but it is unclear if this represents active hunting or indirect scavenging of carcasses. Beringia was submerged during that time period ( $\mathrm{Hu}$ et al. 2010), and it was not until $\sim 110,000$ years ago that the land bridge fleetingly formed, facilitating terrestrial migrations of megafauna (Timmermann and Friedrich 2016). If reliable, the most likely time of terrestrial dispersal would have been during MIS-6.

From the perspective of Wallacea, it is not unfeasible that hominins, whether early $H$. sapiens or another population such as northern Denisovans, could have crossed open water gaps to reach North America. However, I would stress that there are key environmental differences in water temperature, marine biodiversity, open-sea distances, prey abundance, and availability of raw materials (see Anderson 2018), which would likely discount the possibility of hominins venturing through northern Pacific waters prior to Late Pleistocene H. sapiens.

Due to these ecological factors, the Americas' evidence provides an intriguing comparison to the Indo-Pacific records of seafaring and voyaging, which primarily occurred in tropical and subtropical bodies of water. By contrast, the coastal dispersal of our species down the western fringe of the Americas seems to have been associated with regular use of maritime technologies and the long-distance transfer of lithic materials, but water crossings themselves were restricted to short distances of under $10 \mathrm{~km}$ and, when undertaken, targeted known locations of rich offshore resources.

\section{The Mediterranean: An Express Route or Major Hurdle?}

Alongside the seafaring "nurseries" of Wallacea and the Bismarcks (see Irwin 1994, p. 31), the Mediterranean is the only other topographically similar hub of early water-crossing activity in the world (Broodbank 2006). Like Wallacea, the archipelagos of the eastern Mediterranean provide a change in geography; instead of the coast and offshore islands following a center-periphery model and providing a corridor for migration, or acting as steppingstones between continents, these areas challenged hominins to think differently about space and their environment. Here, different species were presented with large groups of islands with variable resource abundance that could, potentially, facilitate complex movements and interactions in their own right.

The question has resurfaced: did Lower-Middle Paleolithic hominins cross into the Mediterranean islands during the Middle and Late Pleistocene? That time frame would make $H$. antecessor, $H$. heidelbergensis, $H$. neanderthalensis, and $H$. sapiens all contenders for the earliest water crossings into the islands (see Bartsiokas et al. 2017; Harvati et al. 2009; Martinez and Arsuaga 1997). Runnels (2014) argues that the Mediterranean may have been a Pleistocene express route for different hominin species moving from Africa into the European peninsula rather than a biogeographic barrier, due to similarities between material culture traditions around North Africa, Greece, and on some of the Mediterranean islands (e.g., Galanidou et al. 2016; Tourloukis and Karkanas 2012). To test this, Howitt-Marshall and Runnels (2016) formulate four working hypotheses: that "archaic" hominins were present on the 
islands; that the islands were separated from the mainland during occupation; that cognitive and technological abilities were sufficient to produce watercraft; and that these abilities included wayfinding skills for open-sea crossings. If this multispecies model is demonstrated to be correct with future research, it will drastically revise how we understand the peopling of western Eurasia, potential "backwash" migrations into Africa, and long-term exchanges of materials, genes, and ideas between the two.

The most convincing support for the multispecies model comes from the Plakias region of southern Crete (Fig. 10), where "Acheulean" lithics, including bifaces and large cutting tools typologically assigned to the Lower Paleolithic, have been found in association with paleosols and uplifted sedimentary terraces (Strasser et al. 2010). The Preveli 2 site lies on marine terraces dated by OSL to c. 45,000-50,000 years ago, providing a minimum possible age for occupation (Strasser et al. 2011), while sediments at Preveli 7, bracketing artifact-bearing layers, have been dated to c. 100,000-130,000 years ago (Runnels et al. 2014a). Farther west at Loutro, handaxes and other tools made on black flint and limestone have been assigned typologically to the late Lower Paleolithic and early Middle Paleolithic, but they lack direct dating (Mortensen 2008). Similarly, at Mochlos in northeast Crete, an undated quaternary alluvial fan is alleged to contain quartz bifaces with affinities to the Lower and Middle Paleolithic on mainland Greece (Runnels et al. 2014b). As Crete was always separated from both Europe and Africa by large channels (Table 2), Pleistocene occupation on the island would have required sophisticated water crossings, probably facilitated by rafts or watercraft.

On Gavdos Island, separated from Crete by the Libyan Sea, a large proportion of surface finds indicate occupation during the Middle and Late Pleistocene (Kopaka and Matzanas 2009). From the site of Ayios Pavlos-Fetifes, a number of "Paleolithic tools" have been used to construct a tentative temporal sequence stretching from the

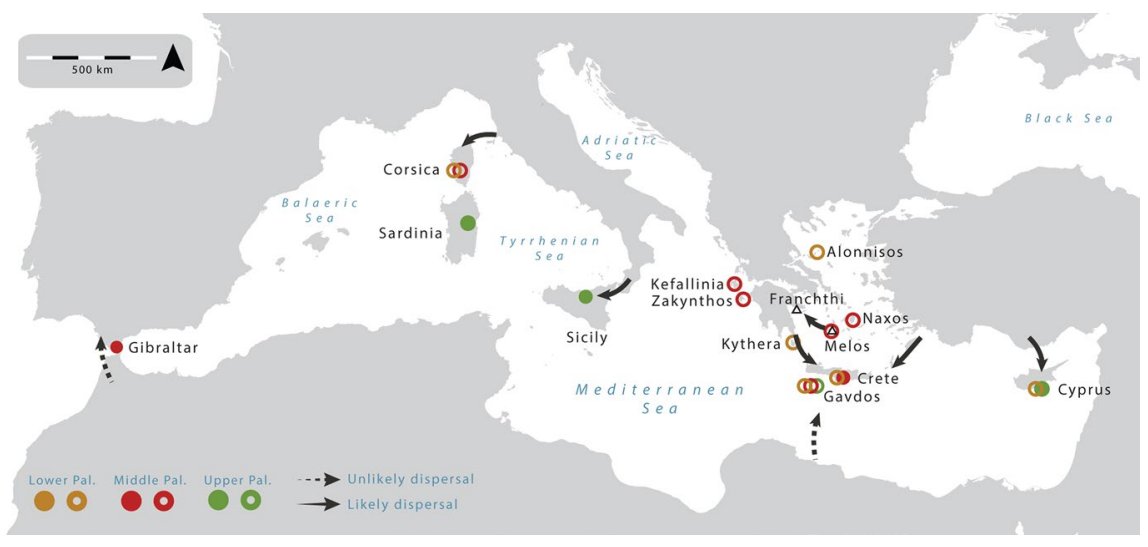

Fig. 10 Map of archaeological evidence for Pleistocene water crossings in the Mediterranean. Artifacts in association with direct dating marked as filled circles; sporadic undated surface finds with purported Paleolithic and Mesolithic attributes marked as hollow circles. For color legend please refer to online version of the article 
Lower Paleolithic through to the Mesolithic (Table S2; Kopaka and Matzanas 2009). This includes chert and black flint implements possibly deriving from Crete. Melian obsidian in the form of a large blade is also present and thought to indicate longdistance maritime contacts by the Mesolithic.

There also are claims for Middle Pleistocene occupation in the Cyclades. Typologically, chert and sandstone artifacts at Stélida on Naxos are suggested to be both Lower Mesolithic and early Middle Paleolithic (Carter et al. 2014), corresponding to 250,000 and 9,000 years ago. Lykousis (2009) suggests that Naxos was possibly connected to mainland Greece and Anatolia during the corresponding glacial periods MIS-6, MIS-8, and MIS-10-MIS-12, although the island's endemic dwarfed fauna does not support this. In MIS-2 and perhaps MIS-3 corresponding to the Upper Paleolithic and Mesolithic, Naxos was part of the larger island of Cycladia but separated from Euboea by a single short water crossing (Table 2). Chert sources have been geochemically characterized, which will allow for future sourcing studies to assign excavated lithics on other islands to the Stélida outcrops (Skarpelis et al. 2017). Given the relatively extensive exploitation of the outcrop, and the long-range mobility behaviors of hunter-gathering hominins, we would expect this material to appear elsewhere around the islands and on the mainland, which would shed additional light on the question of inter-island travel. Ongoing excavations at Stélida aim to establish artifacts in stratigraphic position (Carter, personal communication 2019).

On Kefallinia and Zakynthos, in the Ionian Islands, surface finds suggest that occupation by $H$. neanderthalensis began in the Middle Paleolithic (Table S2), perhaps 110,000-35,000 years ago (Ferentinos et al. 2012). This would have required crossing straits that were 5-12 km wide; Ferentinos et al. (2012) posit that the favorable microclimatic conditions in the area played an important role in allowing safe experimentation with water crossings.

Additional possible Lower-Middle Paleolithic surface finds derive from Melos, Alonnisos, Cyprus, and Corsardinia, which were all variably insular during the Pleistocene (Chelidonio 2001; Efstratiou et al. 2014; Panagopoulou et al. 2001; Sondaar et al. 1986; Strasser et al. 2016). To summarize, these tentatively assigned and predominantly undated "Paleolithic tools" are at the center of the debate, but they lack standardized technological analysis, interlaboratory scrutiny, and systematic reporting. A recent review of the lithic evidence from all of the above-mentioned sites supports assigning some of the tools to the Middle Paleolithic but not the Lower Paleolithic (Papoulia 2017). This suggests that H. neanderthalensis were the first to enter the Mediterranean islands, followed by $H$. sapiens, strengthening interpretations by Broodbank (2006) and Leppard (2014), although this remains open to future revision given strategic fieldwork efforts to examine the Middle-Late Pleistocene record on the Greek islands that began only a decade ago (Runnels, personal communication 2019).

It is not certain if hominins made water crossings exclusively in the eastern Mediterranean or if the Strait of Gibraltar also could have been a viable passage (Rolland 2013). Based on biogeographic, genetic, and paleontological data, it is an unlikely route (O'Regan et al. 2006), and to date, evidence for Pleistocene water crossings is absent in the western Mediterranean (Ramis and Alcover 2001). However, at 
Vanguard and Gorham's Caves in Gibraltar, Neanderthals commonly used coastal resources including marine shell, seals, dolphins, and fish, perhaps as part of broader residential mobility patterns (Stringer et al. 2008). This also occurred in other parts of the Iberian Peninsula and North Africa (Bicho and Haws 2008; Ramos et al. 2008), and there was shell tool manufacture at several sites on mainland Greece and Italy (Douka and Spinapolice 2012). The reliability of coastal environments is evident by the fact these areas were some of the last places that $H$. neanderthalensis survived (Finlayson 2008).

The record for Upper Paleolithic island occupation is sparse but more secure. Following an advance of $H$. sapiens through continental Europe and the coast of the Mediterranean basin from 45,000 to 40,000 years ago, small numbers of humans seem to have entered the islands of the central and eastern Mediterranean. The first confirmed evidence for Pleistocene seagoing is on Sardinia, which would have formed one larger island with Corsica, named Corsardinia. The fauna of the island is endemic, indicating the island was cut off from continental Europe throughout the Pleistocene. At the cave site of Corbeddu, bone artifacts have been radiocarbon dated to c. 15,000 years ago (Sondaar et al. 1986). The site is situated in a valley system perforated with a number of caves that could have served as a thoroughfare for migrating H. sapiens and also large game (Skeates 2012). Arriving on the island the colonists were confronted with a hugely reduced faunal diversity, but they seem to have rapidly adapted, specializing on large deer (Megaceros) hunting supplemented by small mammals (ochotonids). Some of the faunal remains are burnt and show clear cutmarks (Skeates 2012, p. 20).

The authors argue that hominins also arrived in the Middle Pleistocene, reflected by a sudden and dramatic change in the extended faunal sequence, from a record dominated by an extinct goat, rodents, and ochotonids to one of deer, voles, and the Sardinian pika (Skeates 2012). This seems plausible; however, the arrival of the canid Cynotherium sardous, which specialized in hunting small, fast game, may also account for such a change. Lithic artifacts are found only throughout Layers 2 and 3 , dating to 13,000 years ago, and technological changes are thought to reflect adaptation to different functional activities on the island (Hofmeijer et al. 1989). Human remains from the cave suggest $H$. sapiens, rather than a Middle Pleistocene hominin, were the hunters (Spoor 1999).

Bone accumulations at A Teppa di U Lupinu and Coscia caves in Corsica, dating to the LGM and Terminal Pleistocene, are possibly anthropogenic, with bones reworked in the Holocene (Salotti et al. 2008). However, the bones are not associated with any artifacts or patterns of breakage that would characterize butchery or splitting of green bone to extract marrow. Further, the range of species, mostly comprising small mammals, amphibians, and birds, although not outside the range of Pleistocene human behavior in Wallacea or the Pacific, is inconsistent with assemblages formed on the adjacent mainland both by $H$. neanderthalensis and H. sapiens (Stiner and Kuhn 1992; Vacca 2012) and on Corsardina itself (Sondaar et al. 1986). The hunting of deer on the island seems like a more plausible scenario, and we would expect to see abundant deer remains at the site. Rather, the assemblage closely resembles raptor-genic assemblages from the island (Robert and Vigne 2002). Accumulations by a variety of raptor species at the site are a plausible explanation; this 
problem has recently been stressed in cave sites in Wallacea (Hawkins et al. 2018). Another option to account for the large assemblage of small mammals would be the canid Cynotherium sardous, like at Corbeddu (Lyras et al. 2006). However, as noted by Salotti et al. (2008), the absence of digestive marks usually seen on faunal assemblages produced by owls or carnivore gnawing is striking, so the possibility of human accumulation cannot be totally discounted. The timing of the deposits would be well within the timespan of $H$. sapiens and relatively unsurprising. Evidence for an antler manuport directly dated to c. 8,000-9,000 years ago gives the latest possible date that people could have occupied the cave.

Farther south, there are traces of the Upper Paleolithic on Sicily, at cave sites including Acqua Fituasa, Giovanna, Perciata, Levanzo, Uzzo, San Teodoro, and Addaura, which were all initially occupied c. 17,000-12,000 years ago (Table 1). Genetic and faunal evidence from Grotta d'Oritene suggest $H$. sapiens crossed into Sicily via a land bridge that formed during the LGM (Mannino et al. 2012). At that time the island was connected to peninsular Italy, and hunter-gathering groups using Epigravettian tools targeted familiar terrestrial food sources such as red deer, aurochs, and boar (Bietti 1990). However, during climatic amelioration and gradual insularization in the Terminal Pleistocene, there are indications that humans were gradually adapting their subsistence to an island lifestyle, including the presence of some sea birds at Grotta di Levanzo (Vigliardi 1982), fish at Grotta dell'Uzzo (Piperno et al. 1980), and marine shell at Addaura (Mannino and Thomas 2007), along with isotopic signatures that suggest a minor shift toward marine foods that were common around the Mediterranean coast (Mannino et al. 2011). However, predominantly terrestrial subsistence strategies persevered, perhaps because of the island's large size with open environments that supported large mammals. It is unclear if Sicilian hunter-gatherers developed the use of boat technology to return to the mainland.

Additionally, at Fontana Nuova cave in southern Sicily, a large assemblage of stone tools, faunal remains, and human bone was excavated unsystematically in the early 20th century and typologically assigned to the Aurignacian (Chilardi et al. 1996), which would implicate pre-LGM water crossings by $H$. sapiens perhaps 30,000 years ago. However, direct dating on human and animal bone collagen demonstrates the site is securely associated with the Early Holocene (Di Maida et al. 2019).

Evidence for more extensive reconnaissance and resource acquisition on offshore islands comes indirectly from lithic sourcing. Obsidian artifacts excavated at Franchthi Cave in the northeast Peloponnese and dated to c. 15,000 years ago (Laskaris et al. 2011) have been sourced using fission track to Melos (Durrani et al. 1971). Melos was at all times separated from the mainland and Cycladia, but it lacks evidence for Upper Paleolithic settlement, demonstrating the direct procurement and transport of lithic material by mainland groups using watercraft (Renfrew and Aspinall 1990).

More regular return trips to distant Mediterranean islands began in the Terminal Pleistocene, during a period of rapid cold reversal that resulted in harsh environmental conditions on the mainland (Broodbank 2006). H. sapiens visited Akrotiri Aetokremnos on Cyprus by c. 13,000 years ago (Simmons 1991), which was always 
cut off from Eurasia by substantial water gaps of c. $60 \mathrm{~km}$ and provides a difficult target. This suggests the first arrivals, likely coming from southern Anatolia, were supported by relatively sophisticated seafaring technologies (Bar-Yosef Mayer et al. 2015).

Abundant stone tools at the site, comprising flakes, thumbnail scrapers, burins, and a substantial blade component, are distinct from later Neolithic tool kits, and the associated faunal assemblage is dominated by pygmy hippopotamus, an island endemic that may have been overhunted to extinction (Simmons 1988). However, recent taphonomic analyses suggest that the pygmy hippopotami remains represent the reuse of fossil bone for fires rather than direct predation (Zazzo et al. 2015), although either explanation would account for the human translocation of wild boar to the island to provide a reliable protein resource (Vigne et al. 2009). There is little indication that these early Cypriots caught fish (only one fish bone is present in an Early Holocene layer), but they seem to have extensively collected shellfish from the littoral zone, some of which were later used as beads (Simmons 1999, p. 188).

Unlike in the east, hominins around the Mediterranean basin may have been "reluctant sea-goers" until the very end of the Pleistocene following the LGM (Broodbank 2013, pp. 148-155). As Will et al. (2019) find, in studying the use of coastal resources by different Mediterranean populations, there were many similarities between $H$. sapiens, $H$. neanderthalensis, and other Middle Pleistocene hominins. The differences are revealed in the scale and diversity of coastally adaptive behaviors, with our species more intensively using a wider diversity of marine resources. In a similar way, the Mediterranean record of Pleistocene water crossings attests to early experimentation and visitation by at least $H$. neanderthalensis and Late Pleistocene $H$. sapiens, but the scale and intensity of seafaring by post-LGM $H$. sapiens sets these groups apart. In the following section I synthesize the global data, first examining the overlaps and contrasts between distinct regional Homo populations and then the nature of adaptive flexibility within our species in particular.

\section{Discussion}

\section{Water-Crossing Behaviors Within the Genus Homo}

The global evidence shows that a range of Homo morpho-species indisputably crossed water gaps in the Pleistocene. These likely included $H$. erectus (or a related species including the ancestor of $H$. floresiensis), $H$. neanderthalensis, various unknown Homo such as Denisovans, and H. sapiens. The question is not whether these species made water crossings but how we characterize them and understand the implications for adaptive flexibility. Recent reviews (e.g., Dennell et al. 2014; Leppard 2015b) have cautiously accepted that extinct groups crossed water gaps but have stressed that these dispersals were passive. This contrasts with Runnels (2014) and Bednarik (2003) who assert that many of these species were able to deliberately, and perhaps strategically, make water crossings. As Phoca-Cosmetatou and Rabett (2014) keenly point out, the major disjuncture in this debate relates to a priori expectations of hominin cognitive abilities. Instead of comparing hominin decision 
making against strict criteria of our own abilities for controlled and strategic action, we can use the global data to rethink each regional population and associated watercrossing behaviors in their own right. I posit that some water crossings may have been intentional but fail to meet all of the requirements of strategic dispersal, as we see throughout much of the $H$. sapiens archaeological and ethnographic records.

Biomechanically, it would be possible for many species in our genus to deliberately cross water gaps, either by swimming or rafting (see Anderson 2018). Larson et al. (2007) state that changes to the shoulder in H. floresiensis, part of a broader complex of postcranial changes associated with $H$. erectus but much improved in $H$. sapiens, may be related to throwing. Interlinked with improvements in throwing were improvements in swimming and paddling (see Perry 1983). In support of this, many monkeys and some great apes in states of excitement have recently been observed swimming and diving (see Bender and Bender 2013, which includes video supplementary information). As Bender (2015) notes, hominin abilities to swim were probably not limited by biomechanics but by cognitive abilities to experiment and learn.

If we revisit Leppard's (2015b) three cognitive requirements for deliberate interisland travel, Pleistocene groups needed to premeditate future action, organize themselves anticipating a future unseen goal, and design composite technology. Several comments are relevant. Firstly, the ethnographic analogs for strategic inter-island travel using composite technologies, which fundamentally shape our archaeological imagination, derive from $H$. sapiens populations already engaged with mutigenerational water-crossing traditions. I contend that it is essential to incorporate the diachronic, incremental emergence of hominin innovation into our models. For instance, over the course of a few millennia or more of living coastally, with children growing up as hydrophilic rather than hydrophobic, perhaps experimenting with noncomposite organic floatation devices and paddles, it is not a big leap to see some adventurous individuals daring to make it over to the piece of land they can see in the distance, perhaps fortified by accidental crossings and attempted returns. In many sheltered archipelagos, such as Wallacea and the Mediterranean, these islands might only be several hundred meters or a few kilometers distant, representing very little risk for experimenting hominins.

Secondly, group action among $H$. sapiens and other species is not always premeditated and planned but often involves emulation and imitation without relying on language or a theory of mind (Call and Carpenter 2002; Carter and Charles 2013), and some great apes are even capable of spontaneous collaboration (Suchak et al. 2014). Numerous behavioral experiments involving extant hominines, with limited neocortical capacities compared to all fossil Homo, indicate they are capable of "mental time travel," or episodic future thinking - the ability to project oneself into past and future events-for instance, in anticipating what tools are needed ahead of different activities (Kano and Hirata 2015; Osvath and Osvath 2008). Not only that, but Pan troglodytes at least appear to be able to project the future actions of other individuals within their social group (Osvath and Karvonen 2012). This type of cognition can be differentiated from group-level collective agency required for strategic colonization seen in $H$. sapiens. There is then likely to be a form of water crossings in the "in-between": between passive dispersal and strategic colonization. 
This in-between can be illustrated in the difference between proboscids intentionally migrating across deep channels in Indian and Indonesian waters (deliberate, nonstrategic) and a rodent drifting on a piece of vegetation after a storm (nondeliberate, nonstrategic).

Thirdly, it remains speculative whether producing and using simple watercraft is more cognitively challenging than producing and hafting a core tool, or building shelter, which have been recorded archaeologically among $H$. heidelbergensis, $H$. neanderthalensis, and $H$. sapiens, or whether watercraft were even needed to cross short water gaps, especially in warm equatorial waters (Anderson 2018). As summarized in Table 2, almost all of the water crossings made by hominins prior to MIS-4 took place in these conditions, and likely across water gaps of $30 \mathrm{~km}$ or less. Bowdler (1995) summarizes ethnographic and archaeological data from Australia to suggest that rafting with small bark canoes or swimming logs was usually restricted to less than $10 \mathrm{~km}$, although they could be expanded to $30 \mathrm{~km}$, suggesting that early seaward dispersals by other Homo could have been facilitated by simple flotation devices.

The range of behaviors expressed by eastern Eurasian $H$. erectus, proposed to have made jumps into the Philippines, Sulawesi, and Flores, include megafaunal hunting (organized group activity, Storm 2012), engraving (design abstraction, Joordens et al. 2015), and standardized stone-tool production (vertical learning processes, Miller-Antonio et al. 2004). We also know that these H. erectus had likely evolved relative decentration (the ability to divorce action from concepts of the self and understand lasting consequences) and to coordinate a larger number of concepts, allowing for more complex technological and organizational schemes (Wynn 1993). Analysis of $H$. floresiensis brain capacity (Falk et al. 2005) shows that, like H. erectus, it had derived frontal and temporal lobes and a lunate sulcus in a derived position. As such, it was capable of higher cognitive processing, although it is unclear if there was a trade-off in intellect, with implications for social organization and motor skills (Kubo et al. 2013). The question is, were these populations experimenting with coastal and marine environments, and, if so, were their brains working in a way to induce deliberate water-crossing behaviors? I suggest the Wallacean Early-Middle Pleistocene record, characterized by short water crossings with little evidence for regular return crossings or adaptive changes to subsistence, represents regional behavioral responses of $H$. erectus or related species being confronted with equatorial archipelagos; it is best understood as deliberate logistical range/procurement expansion rather than self-reflexive attempts at colonization.

Although experimental studies have shown that present-day humans with access to Paleolithic technology can deliberately navigate all of the passages crossed by $H$. erectus, or a similar hominin (Bednarik 1998), this does not shed light on whether $H$. erectus could have done the same. Such experiments have actually done a disservice for the case of deliberate $H$. erectus water crossings in preparing highly complex, multipart rafts made from bamboo. This is unnecessary, as $H$. erectus could have deliberately used bundles of mangrove vegetation or bamboo to cross small straits. This seems plausible, given we think most $H$. erectus material culture was noncomposite and did not require extended technological processes to arrive at a useful end result. Over several millennia, such rafts could have been incorporated 
into this regional population's spatial cognition as mobility extenders, just as chimpanzee cognition is extended when extractive technologies are used.

The absence of widespread, sustained occupation by $H$. erectus or other nonsapiens in the smaller islands of Wallacea, however, does suggest that these crossings were not strategic in the way we would understand $H$. sapiens dispersals into identical islands, and the crossings were likely compounded by accidental drifting and inclement weather. It also demonstrates comparative adaptive inflexibility when islands with dramatic biogeographic differences are reached, such as an absence of open woodlands and lakes, a lack of large terrestrial game, or the presence of dense rainforests. Although Sundaland $H$. erectus utilized aquatic resources and hunted large grassland animals, zooarchaeological assemblages in Wallacea are dominated by terrestrial faunas in contrast to specialized utilization of coastal and deep marine foodwebs or rainforest zones seen in Pleistocene $H$. sapiens (Roberts and Amano 2019). As O'Connor et al. (2017a) note, the inability of this specific lineage to quickly adapt their subsistence system may have prevented further expansion eastward into the much smaller and biologically depauperate islands of eastern Wallacea. Moreover, the absence of convincing evidence for $H$. erectus island hopping outside the warm seas of equatorial Wallacea, where water temperatures are frequently around $20^{\circ} \mathrm{C}$ and rafting material is abundant, supports that ecological contingency encouraged water crossings only within some regional populations of this species (Anderson 2018). Certainly, the Southeast Asian population of H. erectus (or another related hominin) must have been behaving differently around the coast compared to western $H$. erectus populations, leading them to reach some islands of Wallacea.

The through-flow currents that pass north-south between the straits separating Bali, Lombok, Komodo, and Flores seem to have undermined other fauna reaching the islands (Sprintall et al. 2014), and it is curious that rodents, proboscids, and hominins were the only notable mammalian fauna to cross the gap from Sunda into the Lesser Sunda Island chain (van den Bergh et al. 2001). Proboscids are excellent swimmers up to c. $50 \mathrm{~km}$ (Johnson 1980; Fig. 2), while rodents are known to drift on bundles of vegetation. It is notable that in all places where water crossing by nonsapiens have been proposed, proboscids also moved there and experienced insular dwarfism (van der Geer et al. 2016), perhaps reflective of highly mobile hunting parties following the migration routes of large game. What is crucial, though, is that the common dwarfing of body size in H. floresiensis and H. luzonensis would suggest there was allopatric speciation and restricted genetic exchange due to limited return trips to Sunda, indicating that initial crossings were outliers of normal behaviors (Leppard 2015a).

At the other end of Eurasia, we can split the Mediterranean record into two thresholds: short jumps needed to reach offshore islands (Cycladia and the Ionian Islands) and slightly larger hurdles needed to get to Crete and Gavdos. Given the ranging abilities of all known hominin hunter-gatherers, it seems likely that the earliest visits to the Mediterranean islands, probably by $H$. neanderthalensis or possibly by $H$. heidelbergensis, involved seasonal or occasional resource acquisition, with return trips to the mainland-and hence no reason to assume colonizing-scale demographics (see Leppard 2015a). 
The lack of natural floating vegetation in the Mediterranean has been cited as one possible reason that African and western Eurasian H. ergaster/erectus/antecessor did not cross into the Mediterranean islands or Arabia by sea. However, there is evidence for $H$. neanderthalensis using hafted stone tools in Germany by 400,000 years ago (Thieme 2005), tar as a bonding agent in Italy by 200,000 years ago (Mazza et al. 2006), and three-ply fiber technology in France by 40,000 years ago (Hardy et al. 2020). Tar manufacture probably involved extended technological sequences of birch bark processing (Kozowyk et al. 2017), while twisted cords imply a comprehension of multicomponent parts and mathematical sets (Hardy et al. 2020). It is plausible that similar adhesives and fibers were used for raft construction to get from Anatolia and peninsular Europe to the Mediterranean islands. Moreover, unlike eastern $H$. erectus and $H$. floresiensis, there is substantially more evidence for $H$. neanderthalensis being coastally adapted, or at least incorporating coastal resources and locations into wider foraging strategies.

Additionally, $H$. neanderthalensis must have learned by teaching and sharing to produce levallois flakes (Morgan et al 2015). Whether verbal instruction or mostly gestural observation and imitation, the technical knowledge needed to produce a tool blank and the foresight understood in the resultant shape and what it would be used for is not too dissimilar to the level of technical knowledge needed to turn a piece of wood into a flotation device, or to string hides and branches together into a boat to make it to the next island within visible eyesight. Furthermore, the cognitive and technological abilities needed to produce the simplest of watercraft (e.g., some bark canoes or simple flotation devices) have been overstated. It does not require that much abstract thought, especially to get to a nearby island that is visible. It seems entirely plausible that $H$. neanderthalensis made short jumps into the Mediterranean, but these should be understood as adventurous range expansion by small groups of coastally accustomed foragers, rather than strategic colonization or intensive adaptation to marine environs (Runnels in press).

The longer crossings to Crete and Gavdos, on the other hand, do imply a level of strategic and planned action not previously ascribed to $H$. neanderthalensis. This may indicate relatively sophisticated seagoing technologies using rafts and, minimally, a hydrophilic population comfortable with the deep sea. Despite this, on Crete itself there is, as yet, no evidence for dramatic, rapid behavioral shifts to adapt to island life during the colonization process, hinting at relatively low adaptive flexibility and experimentation. As Davidson (2001) notes, such short water crossings are remarkable, but they are not in the same order of magnitude as later settlement by $H$. sapiens.

\section{Homo sapiens and Adaptive Flexibility}

By comparison, $H$. sapiens generally made longer distance and more frequent water crossings and expressed substantially greater adaptive flexibility during the colonization process, pushing the boundaries of highly diverse ecotones and using islands and marine environments with greater intensity and regularity than other species. For instance, $H$. sapiens provisioned themselves far more than other species. This 
is seen in the transport of high-quality obsidian from New Britain to New Ireland, from Melos to mainland Greece, from Kozushima to Honshu, and from the Californian mainland to the Channel Islands. The redistribution of obsidian fulfilled utilitarian needs but also conveyed aesthetic value and created meaning during reciprocal exchanges due to its scarcity and fixed origins (Torrence 2005). In a similar way, wild animals and plants were translocated from northern Sahul to the Bismarck Archipelago and Wallacea, from western Eurasia to Cyprus, and possibly from eastern Eurasia to the Ryukyus. These Pleistocene translocations demonstrate a level of forward planning that is not seen in other species (Hofman and Rick 2018); they are precursors to the fully fledged "transported landscapes" of Holocene maritime societies (see Kirch 2017). Despite these few intraspecies commonalities, there is substantial regional variation in how Pleistocene $H$. sapiens utilized islands and how they incorporated water crossings into their everyday life.

Among Asian and Pacific H. sapiens, there is clear evidence for seafaring between landmasses and occasional voyaging to islands like Okinawa, Talaud, and Manus. We also see diversification and specialization of subsistence, with increased reliance on marine, littoral, and island resources (Roberts et al. 2020). The earliest faunal assemblages at these sites suggest colonists were extremely broad spectrum in foraging strategies, and in many places, it is likely that there was a seasonal or sporadic interplay between the coast and inland zones, with groups navigating along the shore but also pushing into the interior via river corridors. The earliest dated $H$. sapiens in Wallacea and Sahul demonstrate long-range mobility, with people moving quickly into a myriad of different ecological zones. The Madjedbebe humans had already moved hundreds of kilometers inland from the northwest Sahul coast where the first settlers would have landed (Clarkson et al. 2017), and in the Ivane Valley of montane northeast Sahul, hunter-gatherers moved between coastal and montane environments from the outset (Summerhayes et al. 2010), in a manner that continued into the Terminal Pleistocene (Gaffney et al. 2015). This process is analogous to movements of $H$. sapiens between the coast and rainforest interiors in East Africa (Shipton et al. 2018).

Although the initial colonizing populations of Sahul, Europe, and America may have preferred continental occupation, Late Pleistocene populations in Wallacea, the Ryukyus, the Bismarck Archipelago, and the Massim had a great propensity to inhabit tiny islands with small tracts of forest and depauperate terrestrial faunas. Small islands may pose a risk to terrestrially adapted groups, but those populations with a long-term history of exploiting the littoral and pelagic zones would find such islands ideal, for instance in the expansion of Pleistocene groups onto Kisar, Talaud, Gebe, and Okinawa. It is in these areas, particularly in eastern Wallacean islands like the Raja Ampat group, that we find the highest marine ecodiversity on the planet, with an abundance of marine and coastal resources. And it is the flexibility to shape subsistence strategies in new directions that enabled $H$. sapiens to monopolize these smaller islands in the first place. In a similar way, Late Holocene populations again showed increasing ingenuity in pushing the use of islands to the limits as they colonized tiny coral islands and reefs, dependent on marine resources and extensive long-distance social networks for survival. 
Burke (2012) argues that $H$. sapiens evolved a distinct spatial cognition, related to frequent long-range mobility and the maintenance of expansive social and material networks, which would have given them an adaptive edge over $H$. neanderthalensis. Similar spatial cognitive advantages probably played an important role in how some lineages of $H$. sapiens populated the islands of Wallacea, East Asia, the Pacific, and perhaps the Americas. We can visualize the wider social and physical islandscape, rich in resource opportunities and featuring a surrounding safety net of related social groups, which would have encouraged much more regular return water crossings during the introduction stage of colonization.

Based on the archaeological data reviewed here, the adaptive flexibility hypothesis appears to hold, as a general rule, for Pleistocene H. sapiens in Wallacea, the Pacific, and the Ryukyus. This includes initial stages of landscape learning and adaptation to island and marine environments. I would stress that these innovations are tethered to long-term behavioral trajectories and scaffolded learning strategies in a myriad of ecological niches, which saw our species moving in and out of novel and challenging environments. It was this physical movement, part of long-range residential foraging strategies in a number of different and changing ecotones, rather than stasis along the coast, that probably led these groups to experiment with watercraft in the first place. It remains unclear if these first experiments occurred in Wallacea or along the coastal fringes of southern Eurasia, Arabia, and Africa.

In contrast, the situation is less convincing in the Mediterranean, and only after the LGM do some groups appear to be regularly seagoing, perhaps seafaring to places like Cyprus. In these islands, there was variable environmental attractiveness so that larger, ecologically stable and more readily accessible islands, such as Corsardinia and Sicily, and smaller islands with high-value resources, such as Melos, were preferred over resource-poor islands. The larger continental islands would have contained similar species to those on the mainland, although with less diversity, while the smaller oceanic islands contained many endemics but low species diversity, especially in higher taxonomic levels (Alcover et al. 1999). There is little evidence that islanders dramatically shifted subsistence strategies in the face of Mediterranean island environments, but one initial attraction to these spaces may have been the lack of predators, making prey species docile and easy to catch; after the disappearance of reliable native fauna, humans engineered their islands, such as Cyprus, to mimic the original ecology by introducing mainland animals.

Local ecologies and long-term behavioral trajectories may explain variations in the Asian and Mediterranean datasets. Although each archipelago is topographically similar, these $H$. sapiens populations at opposite ends of Eurasia seem to have approached islands and water crossings differently. As Cherry and Leppard (2018) note, although all $H$. sapiens were cognitively "capable" of strategic water crossings, the insular Mediterranean with reduced terrestrial resource abundance did not appeal on a mass scale to continental foragers. The signature in Wallacea and particularly the western Pacific, which probably hosted a number of strand-looping groups with inter-island voyaging abilities and social networks, seems to be mostly lacking in the Mediterranean. The Late Pleistocene archaeological signature in fact points to the opposite: either no occupation or very occasional visits from the 
mainland by terrestrially focused groups. That is, Mediterranean islands were not incorporated into $H$. sapiens lifeways as extensively as they were in the east, not because European Pleistocene populations lacked some necessary cognitive ability to colonize the islands, but that their long-term behavioral trajectories did not push them toward the coast or to experiment with watercraft as extensively as in the east.

\section{Measuring the Rate of Hominin Adaptive Flexibility}

The underlying mechanisms of human adaptive flexibility are expressed by the rhythm and tempo of innovative behavioral transformations as hominins crossed into novel environments for the first time. This tests the "rapid flexibility" and "gradual modification" hypotheses against the global data to distinguish if changes took place rapidly, over one or two generations, or if they were slower to unfold, with behaviors maintained over thousands of years by intergenerational cultural traditions.

For most areas of the world, we are lacking sites related to the introduction phase of colonization. This can be mitigated by the strength of the empirical evidence, but for now it does not permit either hypothesis to be accepted or rejected. For instance, there is evidence to support rapid flexibility, particularly in lithic landscape learning that globally characterizes Late Pleistocene $H$. sapiens moving into new islands and scouting out high-quality obsidian, and in the dramatic shifts in subsistence presented in Table S2, which we see among the initial Wallacean, Ryukuan, Bismarck, Santarosae, and Cypriot $H$. sapiens, who shifted away from hunting large mainland animals to make extensive use of the littoral zone and small, hard-to-catch game.

Conversely, in support of the gradual modification hypothesis, the earliest evidence for $H$. sapiens occupying the Indo-Pacific islands occurs in the Bismarck Archipelago and Timor, c. 45,000 years ago. Until recently, this was in line with the earliest dates for the colonization of mainland Sahul. However, in light of new dates of >70,000-60,000 years ago from northwest Australia (Clarkson et al. 2017), we may need to rethink the offshore connect. Although there is clearly evidence for complex maritime technology during the Late Pleistocene, no longer do these sites fit into the initial pulse of migration and perhaps represent a buffering lag of 30,000 years, which allowed coastally adapting people to build confidence in watercraft before they decided to settle islands, whereby pelagic fishing, animal translocation, and marine symbolism subsequently developed over tens of millennia in close proximity to the sea.

Although this leaves the mechanisms of adaptive flexibility unresolved, the two models offer a way forward to test future archaeological evidence. Further research will clearly be needed to shed light on the rate and scale of Pleistocene Homo adaptive flexibility. In particular, research projects in several key areas would allow us to fill in the geographically and temporally expansive gaps. Systematic survey and excavation along stretches of the East African, Arabian, and southern Eurasian coasts with high relief that would have been close to the continental shelf edge prior to MIS-3 (see also Will et al. 2019) could establish if there is evidence for behaviors such as offshore fishing that could implicate watercraft, suggesting that H. sapiens were already adept at rudimentary seagoing before they entered island Wallacea, the 
Ryukyus, and the Pacific. Such investigations on islands along the northern route through Wallacea could examine if there was a contemporary northerly dispersal into northwest Sahul 70-60,000 years ago, along with the nature of their adaptation to the islands, whether rapid or gradual. Research on the Kuril Islands in northeast Eurasia and steep sections of the western coast of the Americas could examine if there is an unbroken link in water-crossing behaviors between what we know occurred in the Japanese islands with that evidenced in California. At reputedly Lower, Middle, and Upper Palaeolithic sites on Mediterranean islands known to be insular throughout the Middle and Late Pleistocene, investigations could clarify how extensively these hominins made water crossings and how they adapted to island life, in particular by increasing the sample of sites that document subsistence activities. We also require finer resolution in our bathymetric and geomorphological data, particularly in the Mediterranean, so that we can better model Pleistocene sea levels relative to tectonic uplift and subsidence (see recent successful approaches by Kealy et al. 2018; Norman et al. 2018). As we face a climate of increasing sea-level rise, targeting these areas, many of which are already at risk of erosion or inundation, will be paramount in the years ahead.

\section{Conclusion}

Twenty years ago, the temporal and spatial range of Pleistocene water crossings was clear cut. We knew that humans had made it across the Wallace Line as far east as the Solomon Islands and that this was a skill reserved for so-called behaviorally modern $H$. sapiens, who had dispersed out of Africa along the southern dispersal route. This paradigm has recently been challenged by a number of discoveries around the world, showing that water crossings also took place in the Early and Middle Pleistocene. The swift accumulation of this evidence called for a review to refine how these water crossings reshape our understanding of hominin behavior.

The emergence of water-crossing behaviors and aquatic lifeways occurred asymmetrically across the globe, which emphasizes that ecological and deep historical contingencies shaped water-crossing behaviors among multiple populations in similar environments rather than inherent capacities for water crossings existing innately within specific species. In particular, the Island Southeast Asia region, with its warm equatorial waters and numerous sheltered archipelagos, was a hub of early expansions across water gaps by $H$. erectus, the ancestors of $H$. floresiensis and H. luzonensis, and perhaps one species of Denisovan hominins. These crossings were likely aided by experimentations in swimming and rafting behaviors. In the Mediterranean, there were similar expansions into islands by $H$. neanderthalensis; however, the presence of earlier hominin groups remains to be empirically demonstrated. All of these Early and Middle Pleistocene crossings represent small-scale seagoing, likely less than $30 \mathrm{~km}$, and intentional range expansions to relatively familiar environments rather than strategic attempts to people new islands and landmasses.

Secondly, our species, specifically populations in the Indo-Pacific, pushed watercrossing behaviors to new extremes, breaking the $30 \mathrm{~km}$ threshold already achieved by other species to move out of sight of land, sometimes on voyages over $200 \mathrm{~km}$ 
long, and, upon reaching new landmasses, shifted their behaviors to adapt to challenges in insular environments. In particular, H. sapiens are the only Pleistocene hominins to utilize very small islands with tight biogeographic constraints in Wallacea, the Ryukyus, the Pacific, and the Americas. Living on these islands required drastic transformations from the adaptive strategies practiced on continental shelves and larger islands. These $H$. sapiens also started to use islands strategically for specific resource acquisition, as people reshaped archipelagos into inter-island exchange networks and manipulated some new environments to better suit human needs by introducing reliable food sources.

Thirdly, upon moving to the coast of mainland Eurasia, it remains unclear if $H$. sapiens required thousands of years to gradually innovate boat technology and water-crossing behaviors or if these transformations occurred rapidly, over such a short space of time that they have become archaeologically imperceptible. These two scenarios can be tested with ongoing and future field research across the globe, and they have important implications for how we understand the rate and scale of human adaptive flexibility. Understanding these mechanisms, especially in the face of new and changing environments, is a central concern if 21 st century hominins are to effectively adapt to our changing environments.

Acknowledgments Incisive review comments from Gary Feinman, Tom Leppard, Curtis Runnels, Glenn Summerhayes, Linda Nicholas, and four anonymous reviewers vastly improved the final manuscript. I also thank Cyprian Broodbank and Graeme Barker for encouraging me to tackle the topic and commenting on drafts, as well as Kristina Douglass, Tristan Carter, Ben Shaw, and Curtis Runnels for providing advice, key references, and in-press manuscripts.

Open Access This article is licensed under a Creative Commons Attribution 4.0 International License, which permits use, sharing, adaptation, distribution and reproduction in any medium or format, as long as you give appropriate credit to the original author(s) and the source, provide a link to the Creative Commons licence, and indicate if changes were made. The images or other third party material in this article are included in the article's Creative Commons licence, unless indicated otherwise in a credit line to the material. If material is not included in the article's Creative Commons licence and your intended use is not permitted by statutory regulation or exceeds the permitted use, you will need to obtain permission directly from the copyright holder. To view a copy of this licence, visit http://creativecommons.org/licen ses/by/4.0/.

\section{References Cited}

Aiello, L. C. (2010). Five years of Homo floresiensis. American Journal of Physical Anthropology 142: 167-179.

Alcover, J. A., Seguí, B., and Bover, P. (1999). Extinctions and local disappearances of vertebrates in the western Mediterranean Islands. In MacPhee, R. D. E., and Sues, H.-D. (eds.), Extinctions in Near Time, Springer, Boston, pp. 165-188.

Allen, J. (2000). From beach to beach: The development of maritime economies in prehistoric Melanesia. Modern Quaternary Research in Southeast Asia 16: 137-176.

Allen, J. Gosden, C., Jones, R., and White, J. P. (1988). Pleistocene dates for the human occupation of New Ireland, northern Melanesia. Nature 331: 707-709.

Allen, J., Gosden, C., and White, J. P. (1989). Human Pleistocene adaptations in the tropical island Pacific: Recent evidence from New Ireland, a Greater Australian outlier. Antiquity 63: 548-561.

Amick, D. S. (1993). Toolstone use and distribution patterns among Western Pluvial Lakes Tradition points from southern Nevada. Current Research in the Pleistocene 10: 49-51. 
Anderson, A. (2013). The antiquity of sustained offshore fishing. Antiquity 87: 879-885.

Anderson, A. (2018). Ecological contingency accounts for earliest seagoing in the Western Pacific Ocean. The Journal of Island and Coastal Archaeology 13: 224-234.

Anderson, A., and Summerhayes, G. (2008). Edge-ground and waisted axes in the Western Pacific Islands: Implications for an example from the Yaeyama Islands, southernmost Japan. Asian Perspectives 47: 45-58.

Anderson, A., Clark, G., Haberle, S., Higham, T., Nowak-Kemp, M., Prendergast, A., et al. (2018). New evidence of megafaunal bone damage indicates late colonization of Madagascar. PLOS One 13: p.e0204368.

Argue, D., Donlon, D., Groves, C., and Wright, R. (2006). Homo floresiensis: Microcephalic, pygmoid, Australopithecus, or Homo? Journal of Human Evolution 51: 360-374.

Argue, D., Groves, C. P., Lee, M. S., and Jungers, W. L. (2017). The affinities of Homo floresiensis based on phylogenetic analyses of cranial, dental, and postcranial characters. Journal of Human Evolution 107: 107-133.

Armitage, S. J., Jasim, S. A., Marks, A. E., Parker, A. G., Usik, V. I., and Uerpmann, H.-P. (2011). The southern route "out of Africa": Evidence for an early expansion of modern humans into Arabia. Science 331: 453-456.

Aubert, M., O'Connor, S., McCulloch, M., Mortimer, G., Watchman, A., and Richer-LaFlèche, M. (2007). Uranium-series dating rock art in East Timor. Journal of Archaeological Science 34: 991-996.

Aubert, M., Brumm, A., Ramli, M., Sutikna, T., Saptomo, E. W., Hakim, B., et al. (2014). Pleistocene cave art from Sulawesi, Indonesia. Nature 514: 223-227.

Aubert, M., Setiawan, P., Oktaviana, A. A., Brumm, A., Sulistyarto, P. H., Saptomo, E. W., et al. (2018). Palaeolithic cave art in Borneo. Nature 564: 254-257.

Aubert, M., Lebe, R., Oktaviana, A. A., Tang, M., Burhan, B., Jusdi, A., et al. (2019). Earliest hunting scene in prehistoric art. Nature 576: 442-445.

Azzi, C. M., Bigliocca, L., and Piovan, E. (1973). Florence radiocarbon dates, I. Radiocarbon 15: 479-487.

Bae, C. J., Wang, W., Zhao, J., Huang, S., Tian, F., and Shen, G. (2014). Modern human teeth from late Pleistocene Luna cave (Guangxi, China). Quaternary International 354: 169-183.

Bailey, G., and Milner, N. (2002). Coastal hunter-gatherers and social evolution: Marginal or central? Before Farming 3-4: 1-15.

Bar-Yosef Mayer, D. E., Kahanov, Y., Roskin, J., and Gildor, H. (2015). Neolithic voyages to Cyprus: Wind patterns, routes, and mechanisms. The Journal of Island and Coastal Archaeology 10: $412-435$.

Barton, H., and White, J. P. (1993). Use of stone and shell artefacts at Balof 2, New Ireland, Papua New Guinea. Asian Perspectives 32: 169-181.

Bartsiokas, A., Arsuaga, J. L., Aubert, M., and Grün, R. (2017). U-series dating and classification of the Apidima 2 hominin from Mani Peninsula, Southern Greece. Journal of Human Evolution 109: 22-29.

Bednarik, R. G. (1998). An experiment in Pleistocene seafaring. The International Journal of Nautical Archaeology 27: 139-149.

Bednarik, R. G. (2003). Seafaring in the Pleistocene. Cambridge Archaeological Journal 13: 41-66.

Bellwood, P. (2017). First Islanders: Prehistory and Human Migration in Island Southeast Asia. John Wiley and Sons, Hoboken.

Bellwood, P., Nitihaminoto, G., Irwin, G. Gunadi, A. W., and Tanudirjo, D. (1998). 35,000 years of prehistory in the northern Moluccas. In Bartstra, G.-J. (ed.), Bird's Head Approaches: Irian Jaya Studies-A Programme for Interdisciplinary Research, A. A. Balkema, Rotterdam, pp. 233-275.

Bender, P. R. (2015). The Use of Convergence as a Tool in the Reconstruction of Human Past, with Special Focus on Water Use in Hominin Evolution, Ph.D. thesis, Faculty of Science, University of Witwatersrand, Johannesburg.

Bender, R., and Bender, N. (2013). Swimming and diving behavior in apes (Pan troglodytes and Pongo pygmaeus): First documented report. American Journal of Physical Anthropology 152: 156-162.

Benjamin, J., Rovere, A., Fontana, A., Furlani, S., Vacchi, M., Inglis, R. H., et al. (2017). Late Quaternary sea-level changes and early human societies in the central and eastern Mediterranean Basin: An interdisciplinary review. Quaternary International 449: 29-57. 
Bettis, E. A., Milius, A. K., Carpenter, S. J., Larick, R., Zaim, Y., Rizal, Y., et al. (2009). Way out of Africa: Early Pleistocene paleoenvironments inhabited by Homo erectus in Sangiran, Java. Journal of Human Evolution 56: 11-24.

Bianchini, G., and Gambassini, P. (1973). La grotta dell'Acqua Fitusa (Agrigento): I. gli scavi e l'industria litica. Rivista di Scienze Preistoriche 28: 3-55.

Bicho, N., and Haws, J. (2008). At the land's end: Marine resources and the importance of fluctuations in the coastline in the prehistoric hunter-gatherer economy of Portugal. Quaternary Science Reviews 27: 2166-2175.

Bietti, A. (1990). The late Upper Paleolithic in Italy: an overview. Journal of World Prehistory 4: 95-155.

Bintanja, R., van de Wal, R. S., and Oerlemans, J. (2005). Modelled atmospheric temperatures and global sea levels over the past million years. Nature 437: 125-128.

Birdsell, J. B. (1977). The recalibration of a paradigm for the first peopling of Greater Australia. In Allen, J., Golson, J., and Jones, R. (eds.), Sunda and Sahul: Prehistoric Studies in Southeast Asia, Melanesia and Australia. Academic Press, London, pp. 113-167.

Blanc, P.-L. (2002). The opening of the Plio-Quaternary Gibraltar Strait: Assessing the size of a cataclysm. Geodinamica Acta 15: 303-317.

Boivin, N. L., Zeder, M. A., Fuller, D. Q., Crowther, A., Larson, G., Erlandson, J. M., Denham, T., and Petraglia, M. D. (2016). Ecological consequences of human niche construction: Examining longterm anthropogenic shaping of global species distributions. Proceedings of the National Academy of Sciences 113: 6388-6396.

Bonetti, R., Di Cesare, P., Guglielmetti, A., Malerba, F., Migliorini, E., Oddone, M., et al. (1998). Fission track dating of obsidian source samples from the Willaumez Peninsula, Papua New Guinea and eastern Australia. Records of the Australian Museum 50: 277-284.

Bosch, M. D., Mannino, M. A., Prendergast, A. L., O’Connell, T. C., Demarchi, B., Taylor, S. M., et al. (2015). New chronology for Ksâr 'Akil (Lebanon) supports Levantine route of modern human dispersal into Europe. Proceedings of the National Academy of Sciences 112: 7683-7688.

Bourgeon, L., Burke, A., and Higham, T. (2017). Earliest human presence in North America dated to the last glacial maximum: new radiocarbon dates from Bluefish Caves, Canada. PLOS One 12: p.e0169486.

Bowdler, S. (1990). Peopling Australasia: The 'coastal colonization' hypothesis re-examined. In Mellars, P. (ed.), The Emergence of Modern Humans: An Archaeological Perspective, Edinburgh University Press, Edinburgh, pp. 327-346.

Bowdler, S. (1995). Offshore islands and maritime explorations in Australian prehistory. Antiquity 69: 945-958.

Bowen, D. Q. (2003). Uncertainty in oxygen isotope stage 11 sea-level: An estimate of $\sim 13 \pm 2 \mathrm{~m}$ from Great Britain. In Droxier, A. W., Poore, R.Z., and Burckle, L. H. (eds.), Earth's Climate and Orbital Eccentricity: The Marine Isotope Stage 11 Question, Geophysical Monograph Series 137, American Geophysical Union, Washington, DC, pp. 131-144.

Braje, T. J., Dillehay, T. D., Erlandson, J. M., Fitzpatrick, S. M., Grayson, D. K., Holliday, V. T., et al. (2017). Were hominins in California 130,000 years ago? PaleoAmerica 3: 200-202.

Brandini, S., Bergamaschi, P., Cerna, M. F., Gandini, F., Bastaroli, F., Bertolini, E., et al. (2017). The Paleo-Indian entry into South America according to mitogenomes. Molecular Biology and Evolution 35: 299-311.

Broodbank, C. (2006). The origins and early development of Mediterranean maritime activity. Journal of Mediterranean Archaeology 19: 199-230.

Broodbank, C. (2013). The Making of the Middle Sea: A History of the Mediterranean from the Beginning to the Emergence of the Classical World, Thames and Hudson, London, pp. 286-360.

Brown, P., Sutikna, T., Morwood, M. J., Soejono, R. P., Saptomo, E. W., and Due, R.A. (2004). A new small-bodied hominin from the Late Pleistocene of Flores, Indonesia. Nature 431: 1055-1061.

Brumm, A. (2010). The Movius Line and the bamboo hypothesis: Early hominin stone technology in Southeast Asia. Lithic Technology 35: 7-24.

Brumm, A., Jensen, G. M., van den Bergh, G. D., Morwood, M. J., Kurniawan, I., Aziz, F., and Storey, M. (2010). Hominins on Flores, Indonesia, by one million years ago. Nature 464: 748-752.

Brumm, A., Bergh, G. D. van den, Storey, M., Kurniawan, I., Alloway, B. V., Setiawan, R., et al. (2016). Age and context of the oldest known hominin fossils from Flores. Nature 534: 249-253.

Brumm, A., Hakim, B., Ramli, M., Aubert, M., van den Bergh, G. D., Li, B., et al. (2018). A reassessment of the early archaeological record at Leang Burung 2, a Late Pleistocene rock-shelter site on the Indonesian island of Sulawesi. PLOS One 13: e0193025. 
Bulbeck, F. D., Sumantri, I., and Hiscock, P. (2004). Leang Sakapao 1, a second dated Pleistocene site from South Sulawesi, Indonesia. Modern Quaternary Research in Southeast Asia 18: 111-128.

Burckle, L. H. (1993). Late Quaternary interglacial stages warmer than present. Quaternary Science Reviews 12: 825-831.

Burdukiewicz, J. M. (2014). The origin of symbolic behavior of Middle Palaeolithic humans: Recent controversies. Quaternary International 326: 398-405.

Burke, A. (2012). Spatial abilities, cognition and the pattern of Neanderthal and modern human dispersals. Quaternary International 247: 230-235.

Call, J., and Carpenter, M. (2002). Three sources of information in social learning. In Dautenhahn, K., and Nehaniv, C. L. (eds.), Complex Adaptive Systems: Imitation in Animals and Artifacts, MIT Press, Cambridge, MA. pp. 211-228.

Cardini, L. (1971). Rinvenimenti paleolitici nella Grotta Giovanna (Siracusa). Atti della XIII Riun, Scient. dell'Istituto ltaliano di Preist e Protostoria 1: 29-35.

Carter, B., and Charles, N. (2013). Animals, agency and resistance. Journal for Theory of Social Behavior 43: 322-340.

Carter, T., Contreras, D., Doyle, S., Mihailovic, D., Moutsiou, T., and Skarpelis, N. (2014). The Stélida Naxos Archaeological Project: New data on the Middle Palaeolithic and Mesolithic Cyclades. Antiquity Project Gallery 88: 341.

Chang, Y. (2013). Human activity and lithic technology between Korea and Japan from MIS 3 to MIS 2 in the Late Paleolithic period. Quaternary International 308: 13-26.

Chappell, J. (1993). Late Pleistocene coasts and human migrations in the Austral region. In Spriggs, M., Yen, D., Ambrose, W., Jones, R., Thorne, A., and Andrews, A. (eds.), A Community of Culture, Department of Prehistory, Australian National University, Canberra, pp. 43-48.

Chelidonio, G. (2001). Manufatti litici su ciottolo da Milos (isole Cicladi). Pegaso: Rivista di Cultura Mediterranea 1: 117-144.

Cherry, J. F. (1981). Pattern and process in the earliest colonization of the Mediterranean islands. Proceedings of the Prehistoric Society 47: 41-68.

Cherry, J. F., and Leppard, T. P. (2018). Patterning and its causation in the pre-Neolithic colonization of the Mediterranean islands (Late Pleistocene to Early Holocene). The Journal of Island and Coastal Archaeology 13: 191-205.

Chilardi, S., Frayer, D. W., Gioia, P., Macchiarelli, R., and Mussi, M. (1996). Fontana Nuova di Ragusa (Sicily, Italy): Southernmost Aurignacian site in Europe. Antiquity 70: 553-563.

Choi, K., and Driwantoro, D. (2007). Shell tool use by early members of Homo erectus in Sangiran, central Java, Indonesia: Cut mark evidence. Journal of Archaeological Science 34: 48-58.

Clarkson, C., Jacobs, Z., Marwick, B., Fullagar, R., Wallis, L., Smith, M., et al. (2017). Human occupation of northern Australia by 65,000 years ago. Nature 547: 306-310.

Cooper, A., and Stringer, C. B. (2013). Did the Denisovans cross Wallace's line? Science 342: 321-323.

Curnoe, D. (2003). Problems with the use of cladistic analysis in palaeoanthropology. Homo 53: 225-234.

Davidson, I. (2001). The requirements for human colonisation of Australia. In Metcalfe, I., Smith, J. M. B., Morwood, M., and Davidson, I. (eds.), Faunal and Floral Migration and Evolution in SE AsiaAustralia, Swets and Zietlinger, Lisse, pp. 399-408.

Davidson, I., and Noble, W. (1992). Why the first colonisation of the Australian region is the earliest evidence of modern human behaviour. Archaeology in Oceania 27: 135-142.

Dennell, R., and Petraglia, M. D. (2012). The dispersal of Homo sapiens across southern Asia: How early, how often, how complex? Quaternary Science Reviews 47: 15-22.

Dennell, R. W., Louys, J., O'Regan, H. J., and Wilkinson, D. M. (2014). The origins and persistence of Homo floresiensis on Flores: Biogeographical and ecological perspectives. Quaternary Science Reviews 96: 98-107.

d'Errico, F. (2003). The invisible frontier: A multiple species model for the origin of behavioral modernity. Evolutionary Anthropology 12: 188-202.

d'Errico, F., Vanhaeren, M., Barton, N., Bouzouggar, A., Mienis, H., Richter, D., et al. (2009). Additional evidence on the use of personal ornaments in the Middle Paleolithic of North Africa. Proceedings of the National Academy of Sciences 106: 16051-16056.

Des Lauriers, M. R. (2011). Of clams and Clovis: Isla Cedros, Baja California, Mexico. In Bicho, N. F., Haws, J. A., and Davis, L. G. (eds.), Trekking the Shore, Springer, New York pp. 161-177. 
Des Lauriers, M. R., Davis, L. G., Turnbull, J., Southon, J. R., and Taylor, R. E. (2017). The earliest shell fishhooks from the Americas reveal fishing technology of Pleistocene maritime foragers. American Antiquity 82: 498-516.

Détroit, F., Dizon, E., Falguères, C., Hameau, S., Ronquillo, W., and Sémah, F. (2004). Upper Pleistocene Homo sapiens from the Tabon cave (Palawan, The Philippines): Description and dating of new discoveries. Comptes Rendus Palevol 3: 705-712.

Détroit, F., Mijares, A. S., Corny, J., Daver, G., Zanolli, C., Dizon, E., et al. (2019). A new species of Homo from the Late Pleistocene of the Philippines. Nature 568: 181-186.

Di Maida, G., Mannino, M. A., Krause-Kyora, B., Jensen, T. Z. T., and Talamo, S. (2019). Radiocarbon dating and isotope analysis on the purported Aurignacian skeletal remains from Fontana Nuova (Ragusa, Italy). PLOS One 14: p.e0213173.

Dillehay, T. D., Ocampo, C., Saavedra, J., Sawakuchi, A. O., Vega, R. M., Pino, M., et al. (2015). New archaeological evidence for an early human presence at Monte Verde, Chile. PLOS One 10: p.e0141923.

Dillehay, T. D., Goodbred, S., Pino, M., Sánchez, V. F. V., Tham, T. R., Adovasio, J., et al. (2017). Simple technologies and diverse food strategies of the Late Pleistocene and Early Holocene at Huaca Prieta, coastal Peru. Science Advances 3: p.e1602778.

Dizon, E. Z. (2003). New direct dating of the human fossils from Tabon Cave, Palawan, Philippines. Proceedings of the Society of Philippine Archaeologists 1: 63-67.

Dizon, E., Détroit, F., Sémah, F., Falguères, C., Hameau, S., Ronquillo, W., and Cabanis, E. (2002). Notes on the morphology and age of the Tabon Cave fossil Homo sapiens. Current Anthropology 43: 660-666.

Douglass, K., Antonites, A. R., Morales, E. M. Q., Grealy, A., Bunce, M., Bruwer, C., and Gough, C. (2018). Multi-analytical approach to zooarchaeological assemblages elucidates Late Holocene coastal lifeways in southwest Madagascar. Quaternary International 471: 111-131.

Douglass, K., Hixton, S., Wright, H. T., Godfrey, L. R., Crowley, B. E., Manjakahery, B., et al. (in press). A critical review of radiocarbon dates clarifies the human settlement of Madagascar. Quaternary Science Reviews.

Douka, K., and Spinapolice, E. E. (2012). Neanderthal shell tool production: Evidence from Middle Palaeolithic Italy and Greece. Journal of World Prehistory 25: 45-79.

Dukas, R. (1998). Evolutionary ecology of learning. In Dukas, R. (ed.), Cognitive Ecology: The Evolutionary Ecology of Information Processing and Decision-making, Chicago University Press, Chicago, pp. 129-174.

Durrani, S. A., Khan, H. A., Taj, M., and Renfrew, C. (1971). Obsidian source identification by fission track analysis. Nature 233: 242-245.

Efstratiou, N., Biagi, P., and Starnini, E. (2014). The Epipalaeolithic site of Ouriakos on the island of Lemnos and its place in the Late Pleistocene peopling of the east Mediterranean region. Adalya 17: $1-23$.

Erlandson, J. M. (2001). The archaeology of aquatic adaptations: Paradigms for a new millennium. Journal of Archaeological Research 9: 287-350.

Erlandson, J. M. (2017). Coastlines, marine ecology, and maritime dispersals in human history. In Boiven, N., Crassard, J., and Petraglia, M. (eds.), Human Dispersal and Species Movement: From Prehistory to Present, Cambridge University Press, Cambridge, pp. 147-163.

Erlandson, J. M., and Braje, T. J. (2011). From Asia to the Americas by boat? Paleogeography, paleoecology, and stemmed points of the northwest Pacific. Quaternary International 239: 28-37.

Erlandson, J. M., Graham, M. H., Bourque, B. J., Corbett, D., Estes, J. A., and Steneck, R. S. (2007). The kelp highway hypothesis: Marine ecology, the coastal migration theory, and the peopling of the Americas. The Journal of Island and Coastal Archaeology 2: 161-174.

Erlandson, J. M., Moss, M. L., and Des Lauriers, M. (2008). Life on the edge: Early maritime cultures of the Pacific Coast of North America. Quaternary Science Reviews 27: 2232-2245.

Erlandson, J. M., Rick, T. C., Braje, T. J., Casperson, M., Culleton, B., Fulfrost, B., et al. (2011). Paleoindian seafaring, maritime technologies, and coastal foraging on California's Channel Islands. Science 331: 1181-1185.

Fagundes, N. J. R., Kanitz, R., Eckert, R., Valls, A. C. S., Bogo, M. R., Salzano, F. M., et al. (2008). Mitochondrial population genomics supports a single pre-Clovis origin with a coastal route for the peopling of the Americas. American Journal of Human Genetics 82: 583-592.

Falk, D., Hildebolt, C., Smith, K., Morwood, M. J., Sutikna, T., Brown, P., et al. (2005). The brain of LB1, Homo floresiensis. Science 308: 242-245. 
Farrera, I., Harrison, S. P., Prentice, I. C., Ramstein, G., Guiot, J., Bartlein, P. J., et al. (1999). Tropical climates at the Last Glacial Maximum: A new synthesis of terrestrial palaeoclimate data. I. Vegetation, lake-levels and geochemistry. Climate Dynamics 15: 823-856.

Ferentinos, G., Gkioni, M., Geraga, M., and Papatheodorou, G. (2012). Early seafaring activity in the southern Ionian Islands, Mediterranean Sea. Journal of Archaeological Science 39: 2167-2176.

Finlayson, C. (2008). On the importance of coastal areas in the survival of Neanderthal populations during the Late Pleistocene. Quaternary Science Reviews 27: 2246-2252.

Fitzpatrick, S. M., and Anderson, A. (2008). Islands of isolation: Archaeology and the power of aquatic perimeters. The Journal of Island and Coastal Archaeology 3: 4-16.

Fladmark, K. (1979). Routes: Alternate migration corridors for early man in North America. American Antiquity 44: 55-69.

Flannery, T. F., and White, J. P. (1991). Animal translocations. National Geographic Research and Exploration 7: 96-113.

Florin, S. A., Fairbairn, A. S., Nango, M., Djandjomerr, D., Marwick, B., Fullagar, R., et al. (2020). The first Australian plant foods at Madjedbebe, 65,000-53,000 years ago. Nature Communications 11: 924.

Foley, R. A. (1991). How many species of hominid should there be? Journal of Human Evolution 20: 413-427.

Fox, R. B. (1970). The Tabon Caves: Archaeological Explorations and Excavations on Palawan Island, Philippines, National Museum of the Philippines, Manilla.

Frederickson, C. (1997). Changes in Admiralty Islands obsidian source use: The view from Pamwak. Archaeology in Oceania 32: 68-73.

Frederickson, C., Spriggs, M., and Ambrose, W. (1993). Pamwak rockshelter: A Pleistocene rockshelter on Manus Island. In Smith, M. A., Spriggs, M., and Fankhauser, B. (eds.), Sahul in Review: Pleistocene Archaeology in Australia and Island Melanesia, Department of Prehistory, Australian National University, Canberra, pp. 144-152.

Fujita, M., Yamasaki, S., Katagiri, C., Oshiro, I., Sano, K., Kurozumi, T., et al. (2016). Advanced maritime adaptation in the western Pacific coastal region extends back to 35,000-30,000 years before present. Proceedings of the National Academy of Sciences 113: 11184-11189.

Gaffney, D., Ford, A., and Summerhayes, G. R. (2015). Crossing the Pleistocene-Holocene transition in the New Guinea Highlands: Evidence from the lithic assemblage of Kiowa rockshelter. Journal of Anthropological Archaeology 39: 223-246.

Galanidou, N., Athanassas, C., Cole, J., Iliopoulos, G., Katerinopoulos, A., Magganas, A., and McNabb, J. (2016). The Acheulian site at Rodafnidia, Lisvori, on Lesbos, Greece: 2010-2012. In Harvati, K., and Roksandic, M. (eds.), Paleoanthropology of the Balkans and Anatolia, Springer, Dordrecht, pp. 119-138.

Gill, K. M., Erlandson, J. M., Hughes, R. E., Origer, T., Rogers, A. K., and Vellanoweth, R. L. (2019). Material conveyance in the Southern California Bight: Obsidian on Alta California's Channel Islands. The Journal of Island and Coastal Archaeology https://doi.org/10.1080/15564 894.2019.1570988.

Glover, I. (1969). Radiocarbon dates from Portuguese Timor. Archaeology and Physical Anthropology in Oceania 4: 107-112.

Glover, I. (1981). Leang Burung 2: An Upper Palaeolithic rock shelter in South Sulawesi, Indonesia. Modern Quaternary Research in Southeast Asia 6: 1-38.

Gorecki, P., Mabin, M., and Campbell, J. (1991). Archaeology and geomorphology of the Vanimo coast, Papua New Guinea: Preliminary results. Archaeology in Oceania 26: 119-122.

Gosden, C., and Malafouris, L. (2015). Process archaeology (p-arch). World Archaeology 47: 701-717.

Groube, L. (1989). The taming of the rain forests: A model for Late Pleistocene forest exploitation in New Guinea. In Harris, D. R., and Hillman, G. C. (eds.), Foraging and Farming, Unwin Hyman, London, pp. 292-304.

Groube, L., Chappell, J., Muke, J., and Price, D. (1986). A 40,000-year-old occupation site at Huon Peninsula, Papua New Guinea. Nature 324: 453-455.

Habgood, P. J., and Franklin, N. R. (2008). The revolution that didn't arrive: A review of Pleistocene Sahul. Journal of Human Evolution 55: 187-222.

Hamada, T. (1985). 14C Age of Charcoal from Pinza-Abu Cave Deposits, Miyako Island, Okinawa, Japan: Reports on Excavation of the Pinza-Abu Cave, Department of Education, Okinawa Prefecture Government, Naha. 
Hanebuth, T. J., Voris, H. K., Yokoyama, Y., Saito, Y., and Okuno, J. I. (2011). Formation and fate of sedimentary depocentres on Southeast Asia's Sunda Shelf over the past sea-level cycle and biogeographic implications. Earth-Science Reviews 104: 92-110.

Hansford, J., Wright, P. C., Rasoamiaramanana, A., Pérez, V. R., Godfrey, L. R., Errickson, D., Thompson, T., and Turvey, S. T. (2018). Early Holocene human presence in Madagascar evidenced by exploitation of avian megafauna. Science Advances 4: eaat6925.

Hardy, B. L., Moncel, M. H., Kerfant, C., Lebon, M., Bellot-Gurlet, L., and Mélard, N. (2020). Direct evidence of Neanderthal fibre technology and its cognitive and behavioral implications. Scientific Reports 10: 4889.

Harvati, K., Panagopoulou, E., and Runnels, C. (2009). The paleoanthropology of Greece. Evolutionary Anthropology 18: 131-143.

Hawkins, S., O'Connor, S., and Louys, J. (2017a). Taphonomy of bird (Aves) remains at Laili Cave, Timor-Leste, and implications for human-bird interactions during the Pleistocene. Archaeological and Anthropological Sciences, https://doi.org/10.1007/s12520-017-0568-4.

Hawkins, S., O’Connor, S., Maloney, T. R., Litster, M., Kealy, S., Fenner, J. N., et al. (2017b). Oldest human occupation of Wallacea at Laili Cave, Timor-Leste, shows broad-spectrum foraging responses to Late Pleistocene environments. Quaternary Science Reviews 171: 58-72.

Hawkins, S., Carro, S. C. S., Louys, J., Aplin, K., O’Connor, S., and Mahirta (2018). Human palaeoecological interactions and owl roosting at Tron Bon Lei, Alor Island, Eastern Indonesia. The Journal of Island and Coastal Archaeology 13: 371-387.

Heaney, L. R. (1991). A synopsis of climatic and vegetational change in Southeast Asia. In Myers, N. (ed.), Tropical Forests and Climate, Springer, Dordrecht, pp. 53-61.

Henneberg, M., Eckhardt, R. B., Chavanaves, S., and Hsü, K. J. (2014). Evolved developmental homeostasis disturbed in LB1 from Flores, Indonesia, denotes Down Syndrome and not diagnostic traits of the invalid species Homo floresiensis. Proceedings of the National Academy of Sciences 111: 11967-11972.

Henshilwood, C. S., Sealy, J. C., Yates, R., Cruz-Uribe, K., Goldberg, P., Grine, F. E., et al. (2001). Blombos Cave, Southern Cape, South Africa: Preliminary report on the 1992-1999 excavations of the Middle Stone Age levels. Journal of Archaeological Science 28: 421-448.

Hiscock, P. (2015). Cultural diversification and the global dispersion of Homo sapiens: Lessons from Australia. In Kaifu, Y., Izuho, M., Goebel, T., Sato, H., and Ono, A. (eds.), Emergence and Diversity of Modern Human Behaviour in Paleolithic Asia, Texas A\&M University Press, College Station, pp. 225-236.

Hoffmann, D. L., Angelucci, D. E., Villaverde, V., Zapata, J., and Zilhão, J. (2018). Symbolic use of marine shells and mineral pigments by Iberian Neandertals 115,000 years ago. Science Advances 4: p.eaar5255.

Hofman, C. A., and Rick, T. C. (2018). Ancient biological invasions and island ecosystems: Tracking translocations of wild plants and animals. Journal of Archaeological Research 26: 65-115.

Hofman, C. A., Rick, T. C., Erlandson, J. M., Reeder-Myers, L., Welch, A. J., and Buckley, M. (2018). Collagen fingerprinting and the earliest marine mammal hunting in North America. Scientific Reports 8: 10014.

Hofmeijer, G. K., Alderliesten, C., Borg, K. V. D., Houston, C. M., Jong, A. F. M., Martini, F., et al. (1989). Dating of the Upper Pleistocene lithic industry of Sardinia. Radiocarbon 31: 986-991.

Holen, S. R., Deméré, T. A., Fisher, D. C., Fullagar, R., Paces, J. B., Jefferson, G. T. et al. (2017). A 130,000-year-old archaeological site in southern California, USA. Nature 544: 479-483.

Hopkins, D. M. (1982). Aspects of the paleogeography of Beringia during the Late Pleistocene. In Hopkins, D. M., Matthews, J. V., Schweger, C. E., and Young, S. B. (eds.), Paleoecology of Beringia, Academic Press, New York, pp. 3-28.

Howitt-Marshall, D., and Runnels, C. (2016). Middle Pleistocene sea-crossings in the eastern Mediterranean? Journal of Anthropological Archaeology 42: 140-153.

Hu, A., Meehl, G. A., Otto-Bliesner, B. L., Waelbroeck, C., Han, W., Loutre, M. F., et al. (2010). Influence of Bering Strait flow and North Atlantic circulation on glacial sea-level changes. Nature Geoscience 3: 118-121.

Hublin, J.-J., Ben-Ncer, A., Bailey, S. E., Freidline, S. E., Neubauer, S., Skinner, M. M., et al. (2017). New fossils from Jebel Irhoud, Morocco and the pan-African origin of Homo sapiens. Nature 546: 289.

Hyodo, M., Matsu'ura, S., Kamishima, Y., Kondo, M., Takeshita, Y., Kitaba, I., et al. (2011). Highresolution record of the Matuyama-Brunhes transition constrains the age of Javanese Homo 
erectus in the Sangiran dome, Indonesia. Proceedings of the National Academy of Sciences 108: $19563-19568$.

Ikawa-Smith, F. (2008). Living on the edge of the continent: The Japanese Archipelago 30,000-8,000 cal BC. North Pacific Prehistory 2: 45-64.

Ikeya, N. (2015). Maritime transport of obsidian in Japan during the Upper Palaeolithic. In Kaifu, Y., Izuho, M., Goebel, T., Sato, H., and Ono, A. (eds.), Emergence and Diversity of Modern Human Behaviour in Paleolithic Asia, Texas A\&M University Press, College Station, pp. 362-375.

Ingicco, T., Bergh, G. D., Jago-On, C., Bahain, J. J., Chacón, M. G., Amano, N., et al. (2018). Earliest known hominin activity in the Philippines by 709 thousand years ago. Nature 557: 233-237.

Ingold, T. (2003). Three in one: How an ecological approach can obviate the distinctions between body, mind and culture. In Roepstorff, A., Bubandt, N., and Kull, K. (eds.), Imagining Nature: Practices of Cosmology and Identity, Aarhus University Press, Aarhus, pp. 40-55.

Irwin, G. (1994). The Prehistoric Exploration and Colonisation of the Pacific, Cambridge University Press, Cambridge.

Iwase, A., Hashizume, J., Izuho, M., Takahashi, K., and Sato, H. (2012). Timing of megafaunal extinction in the late Late Pleistocene on the Japanese Archipelago. Quaternary International 255: 114-124.

Iwase, A., Takahashi, K., and and Izuho, M. (2015). Further study on the Late Pleistocene megafaunal extinction in the Japanese Archipelago. In Kaifu, Y., Izuho, M., Goebel, T., Sato, H., and Ono, A. (eds.), Emergence and Diversity of Modern Human Behaviour in Paleolithic Asia, Texas A\&M University Press, College Station, pp. 325-344.

Izuho, M., and Kaifu, Y. (2015). The appearance and characteristics of the early Upper Paleolithic in the Japanese Archipelago. In Kaifu, Y., Izuho, M., Goebel, T., Sato, H., and Ono, A. (eds.), Emergence and Diversity of Modern Human Behaviour in Paleolithic Asia, Texas A\&M University Press, College Station, pp. 289-313.

Jacobs, G. S., Hudjashov, G., Saag, L., Kusuma, P., Darusallam, C. C., Lawson, D. J., et al. (2019). Multiple deeply divergent Denisovan ancestries in Papuans. Cell 177: 1010-1021.e32.

Johnson, D. L. (1980). Problems in the land vertebrate zoogeography of certain islands and the swimming powers of elephants. Journal of Biogeography 7: 383-398.

Joordens, J. C. A., Wesselingh, F. P., de Vos, J., Vonhof, H. B., and Kroon, D. (2009). Relevance of aquatic environments for hominins: A case study from Trinil (Java, Indonesia). Journal of Human Evolution 57: 656-671.

Joordens, J. C. A., d'Errico, F., Wesselingh, F. P., Munro, S., Vos, J. de, Wallinga, J., et al. (2015). Homo erectus at Trinil on Java used shells for tool production and engraving. Nature 518: 228-231.

Kaifu, Y. (2017). Archaic hominin populations in Asia before the arrival of modern humans: Their phylogeny and implications for the "southern Denisovans." Current Anthropology 58: S418-S433.

Kaifu, Y., Fujita, M., Yoneda, M., and Yamasaki, S. (2015). Pleistocene seafaring and colonization of the Ryukyu Islands, southwestern Japan. In Kaifu, Y., Izuho, M., Goebel, T., Sato, H., and Ono, A. (eds.), Emergence and Diversity of Modern Human Behaviour in Paleolithic Asia, Texas A\&M University Press, College Station, pp. 345-361.

Kano, F., and Hirata, S. (2015). Great apes make anticipatory looks based on long-term memory of single events. Current Biology 25: 2513-2517.

Kealy, S., Louys, J., and O'Connor, S. (2017). Reconstructing palaeogeography and inter-island visibility in the Wallacean Archipelago during the likely period of Sahul colonization, 65-45 000 years ago. Archaeological Prospection 24: 259-72.

Kealy, S., Louys, J., and O'Connor, S. (2018). Least-cost pathway models indicate northern human dispersal from Sunda to Sahul. Journal of Human Evolution 125: 59-70.

Keegan, W. F., and Diamond, J. M. (1987). Colonization of islands by humans: A biogeographical perspective. Advances in Archaeological Method and Theory 10: 49-92.

Kennedy, J. (2002). Manus from the beginning: An archaeological overview. In Kaufmann, C., KocherSchmid, C., and Ohnemus, S. (eds.), Admiralty Art: Art from the South Seas, Museum Rietberg, Zurich, pp. 17-28.

Kirch, P. V. (2017). On the Road of the Winds: An Archaeological History of the Pacific Islands Before European Contact, University of California Press, Berkeley.

Klein, R. G. (2008). Out of Africa and the evolution of human behavior. Evolutionary Anthropology 17: 267-281.

Kobayashi, H., Matsui, Y., and Suzuki, H. (1971). University of Tokyo radiocarbon measurements IV. Radiocarbon 13: 97-102. 
Kobayashi, H., Hirose, T., Sugino, M., and Watanabe, N. (1974). University of Tokyo radiocarbon measurements V. Radiocarbon 16: 381-387.

Kopaka, K., and Matzanas, C. (2009). Palaeolithic industries from the island of Gavdos, near neighbour to Crete in Greece. Antiquity Project Gallery 83: 321.

Kozlovsky, D. Y., Branch, C. L., and Pravosudov, V. V. (2015). Problem-solving ability and response to novelty in mountain chickadees (Poecile gambeli) from different elevations. Behavioral Ecology and Sociobiology 69: 635-643.

Kozowyk, P. R. B., Soressi, M., Pomstra, D., and Langejans, G. H. J. (2017). Experimental methods for the Palaeolithic dry distillation of birch bark: Implications for the origin and development of Neandertal adhesive technology. Scientific Reports 7: 8033.

Kress, J. H., (1978). The ceramics from Pilanduk Cave and Sa'gung Rockshelter, Quezon Municipality, Palawan Island, the Philippines. Asian Perspectives 21: 58-85.

Kubo, D., Kono, R. T., and Kaifu, Y. (2013). Brain size of Homo floresiensis and its evolutionary implications. Proceedings of the Royal Society of London B 280: 20130338.

Kuzmin, Y. V., and Keates, S. G. (2014). Direct radiocarbon dating of Late Pleistocene hominids in Eurasia: Current status, problems, and perspectives. Radiocarbon 56: 753-766.

Kyriacou, K., Blackhurst, D. M., Parkington, J. E., and Marais, A. D. (2016). Marine and terrestrial foods as a source of brain-selective nutrients for early modern humans in the southwestern Cape, South Africa. Journal of Human Evolution 97: 86-96.

Laland, K. N., and Brown, G. R. (2006). Niche construction, human behavior, and the adaptive-lag hypothesis. Evolutionary Anthropology 15: 95-104.

Lambeck, K., Purcell, A., Flemming, N. C., Vita-Finzi, C., Alsharekh, A. M., and Bailey, G. N. (2011). Sea level and shoreline reconstructions for the Red Sea: Isostatic and tectonic considerations and implications for hominin migration out of Africa. Quaternary Science Reviews 30: 3542-3574.

Langley, M. C., O'Connor, S., and Piotto, E. (2016). 42,000-year-old worked and pigment-stained Nautilus shell from Jerimalai (Timor-Leste): Evidence for an early coastal adaptation in ISEA. Journal of Human Evolution 97: 1-16.

Larson, S. G., Jungers, W. L., Morwood, M. J., Sutikna, T., Jatmiko, Saptomo, E. W., Due, R. A., and Djubiantono, T. (2007). Homo floresiensis and the evolution of the hominin shoulder. Journal of Human Evolution 53: 718-731.

Laskaris, N., Sampson, A., Mavridis, F., and Liritzis, I. (2011). Late Pleistocene/Early Holocene seafaring in the Aegean: New obsidian hydration dates with the SIMS-SS method. Journal of Archaeological Science 38: 2475-2479.

Leavesley, M. G. (2004). Trees to the Sky: Prehistoric Hunting in New Ireland, Papua New Guinea, Ph.D. thesis, School of Archaeology and Anthropology, Australian National University, Canberra.

Leavesley, M. G. (2007). A shark-tooth ornament from Pleistocene Sahul. Antiquity 81: 308-315.

Leavesley, M., and Allen, J. (1998). Dates, disturbance and artefact distributions: Another analysis of Buang Merabak, a Pleistocene site on New Ireland, Papua New Guinea. Archaeology in Oceania 33: 63-82.

Lentfer, C., Pavlides, C., and Specht, J. (2010). Natural and human impacts in a 35,000-year vegetation history in central New Britain, Papua New Guinea. Quaternary Science Reviews 29: 3750-3767.

Leppard, T. P. (2014). Modeling the impacts of Mediterranean island colonization by archaic hominins: The likelihood of an insular Lower Palaeolithic. Journal of Mediterranean Archaeology 27: 231-254.

Leppard, T. P. (2015a). Passive dispersal versus strategic dispersal in island colonization by hominins. Current Anthropology 56: 590-595.

Leppard, T. P. (2015b). The evolution of modern behaviour and its implications for maritime dispersal during the Palaeolithic. Cambridge Archaeological Journal 25: 829-846.

Leppard, T. P. (2015c). Adaptive responses to demographic fragility: Mitigating stochastic effects in early island colonization. Human Ecology 43: 721-734.

Leppard, T. P. (2016). Between deterministic and random process in prehistoric Pacific Island abandonment. Journal of Pacific Archaeology 7: 20-25.

Leppard, T. P., and Runnels, C. (2017). Maritime hominin dispersals in the Pleistocene: Advancing the debate. Antiquity 91: 510-519.

Lewis, H., Paz, V., Lara, M., Barton, H., Piper, P., Ochoa, J., et al. (2008). Terminal Pleistocene to midHolocene occupation and an early cremation burial at Ille Cave, Palawan, Philippines. Antiquity 82: $318-335$. 
Li, F., Kuhn, S. L., Chen, F., Wang, Y., Southon, J., Peng, F., et al. (2018). The easternmost Middle Paleolithic (Mousterian) from Jinsitai Cave, North China. Journal of Human Evolution 114: 76-84.

Liebl, A. L., and Martin, L. B. (2014). Living on the edge: Range edge birds consume novel foods sooner than established ones. Behavioral Ecology 25: 1089-1096.

Liu, W., Martinón-Torres, M., Cai, Y. J., Xing, S., Tong, H. W., Pei, S. W., et al. (2015). The earliest unequivocally modern humans in southern China. Nature 526: 696-699.

Louys, J., and Turner, A. (2012). Environment, preferred habitats and potential refugia for Pleistocene Homo in Southeast Asia. Comptes Rendus Palevol 11: 203-211.

Lowe, J. J., and Walker, M. J. (2014). Reconstructing Quaternary Environments, Routledge, London.

Loy, T., Spriggs, M., and Wickler, S. (1992). Direct evidence for human use of plants 28,000 years ago: Starch residues on stone artefacts from the northern Solomon Islands. Antiquity 66: 898-912.

Lykousis, V. (2009). Sea-level changes and shelf break prograding sequences during the last 400ka in the Aegean margins: Subsidence rates and palaeogeographic implications. Continental Shelf Research 29: 2037-2044.

Lyras, G. A., Geer, A. A. E., Dermitzakis, M. D., and Vos, J. D. (2006). Cynotherium sardous, an insular canid (Mammalia: Carnivora) from the Pleistocene of Sardinia (Italy), and its origin. Journal of Vertebrate Paleontology 26: 735-745.

Mahirta (2003). Human Occupation on Roti and Sawu Islands, Nusa Tenggara Timur, Ph.D. thesis, Department of Prehistory, Australian National University, Canberra.

Malafouris, L. (2013). How Things Shape the Mind, MIT Press, Cambridge, MA.

Manalo, K. (2011). Preliminary identification of cutmarks morphology on animal bones: Methods and applications. MA thesis, Department of Archaeology, University of the Philippines, Quezon City, Philippines.

Mannino, M. A., and Thomas, K. D. (2007). New radiocarbon dates for hunter-gatherers and early farmers in Sicily. Accordia Research Papers 10: 13-34.

Mannino, M. A., Di Salvo, R., Schimmenti, V., Di Patti, C., Incarbona, A., Sineo, L., and Richards, M. P. (2011). Upper Palaeolithic hunter-gatherer subsistence in Mediterranean coastal environments: An isotopic study of the diets of the earliest directly-dated humans from Sicily. Journal of Archaeological Science 38: 3094-3100.

Mannino, M. A., Catalano, G., Talamo, S., Mannino, G., Salvo, R. D., Schimmenti, V., et al. (2012). Origin and diet of the prehistoric hunter-gatherers on the Mediterranean island of Favignana (Ègadi Islands, Sicily). PLOS One 7: e49802.

Marean, C. W. (2014). The origins and significance of coastal resource use in Africa and western Eurasia. Journal of Human Evolution 77: 17-40.

Marean, C. W., Bar-Matthews, M., Bernatchez, J., Fisher, E., Goldberg, P., Herries, A. I. R., et al. (2007). Early human use of marine resources and pigment in South Africa during the Middle Pleistocene. Nature 449: 905-908.

Marshall, B., and Allen, J. (1991). Excavations at Panakiwuk Cave, New Ireland. In Allen, J., and Gosden, C. (eds.), Report of the Lapita Homeland Project, Department of Prehistory, Australian National University, Canberra, pp. 59-91.

Martin, R. D., MacLarnon, A. M., Phillips, J. L., and Dobyns, W. B. (2006). Flores hominid: New species or microcephalic dwarf? The Anatomical Record Part A: Discoveries in Molecular, Cellular, and Evolutionary Biology 288: 1123-1145.

Martinez, I., and Arsuaga, J. L. (1997). The temporal bones from Sima de los Huesos Middle Pleistocene site (Sierra de Atapuerca, Spain): A phylogenetic approach. Journal of Human Evolution 33: 283-318.

Martinón-Torres, M., Wu, X., Bermúdez de Castro, J. M., Xing, S., and Liu, W. (2017). Homo sapiens in the eastern Asian Late Pleistocene. Current Anthropology 58: S434-S448.

Matsufuji K., (2011). When were the earliest hominin migrations to the Japanese islands? In Norton, C. J., and Braun, D. R. (eds.), Asian Palaeoanthropology, Springer, Dordrecht, pp. 191-200.

Matsu'ura, S. (1999). A chronological review of Pleistocene human remains from the Japanese Archipelago. In Omoto, K. (ed.), Interdisciplinary Perspectives on the Origins of the Japanese, International Research Center for Japanese Studies, Kyoto, pp. 181-197.

Mazza, P. P. A., Martini, F., Sala, B., Magi, M., Colombini, M. P., Giachi, G., et al. (2006). A new Palaeolithic discovery: Tar-hafted stone tools in a European mid-Pleistocene bone-bearing bed. Journal of Archaeological Science 33: 1310-1318.

McBrearty, S., and Brooks, A. S. (2000). The revolution that wasn't: A new interpretation of the origin of modern human behavior. Journal of Human Evolution 39: 453-563. 
Mellars, P. (2005). The impossible coincidence: A single-species model for the origins of modern human behavior in Europe. Evolutionary Anthropology 14: 12-27.

Mijares, A. (2006). Tracking the early human migration into Island Southeast Asia. Hukay 10: 3-24.

Mijares, A. S. (2007). Unearthing Prehistory: The Archaeology of Northeastern Luzon, Philippine Islands, British Archaeological Reports, Oxford.

Mijares, A. S. (2015). Human emergence and adaptation to an island environment in the Philippine Paleolithic. In Kaifu, Y., Izuho, M., Goebel, T., Sato, H., and Ono, A. (eds.), Emergence and Diversity of Modern Human Behaviour in Paleolithic Asia, Texas A\&M University Press, College Station, pp. 171-181.

Mijares, A. S., Détroit, F., Piper, P., Grün, R., Bellwood, P., Aubert, M., et al. (2010). New evidence for a 67,000-year-old human presence at Callao Cave, Luzon, Philippines. Journal of Human Evolution 59: $123-132$.

Miller-Antonio, S., Schepartz, L.A., Karkanas, P., Yamei, H., Weiwen, H., and Bekken, D. (2004). Lithic raw material use at the late Middle Pleistocene site of Panxian Dadong. Asian Perspectives 43: $314-332$.

Mitchell, P. (2004). Towards a comparative archaeology of Africa's islands. Journal of African Archaeology 2: 229-250.

Morgan, T. J., Uomini, N. T., Rendell, L. E., Chouinard-Thuly, L., Street, S. E., Lewis, H. M., et al. (2015). Experimental evidence for the co-evolution of hominin tool-making teaching and language. Nature Communications 6: 6029.

Morisaki, K. (2015). Appearance of Hakuhen-Sentoki (HS points) and second modern human migration into Kyushu, Japan. In Kaifu, Y., Izuho, M., Goebel, T., Sato, H., and Ono, A. (eds.), Emergence and Diversity of Modern Human Behaviour in Paleolithic Asia, Texas A\&M University Press, College Station, pp. 376-388.

Mortensen, P. (2008). Lower to Middle Palaeolithic artefacts from Loutró on the south coast of Crete. Antiquity Project Gallery 82: 317.

Morwood, M. J. (2014). Faunal biogeography in Island Southeast Asia. In Dennell, R., and Porr, M. (eds.), Southern Asia, Australia, and the Search for Human Origins, Cambridge University Press, Cambridge, pp. 108-117.

Morwood, M. J., and van Oosterzee, P. (2007). A New Human: The Startling Discovery and Strange Story of the "Hobbits" of Flores, Indonesia, Left Coast Press, Walnut Creek, CA.

Morwood, M. J., O’Sullivan, P. B., Aziz, F., and Raza, A. (1998). Fission-track ages of stone tools and fossils on the east Indonesian island of Flores. Nature 392: 173-176.

Morwood, M. J., Aziz, F., O’Sullivan, P., Hobbs, D. R., and Raza, A. (1999). Archaeological and palaeontological research in central Flores, east Indonesia: Results of fieldwork 1997-98. Antiquity 73: 273-286.

Morwood, M. J., Soejono, R. P., Roberts, R. G., Sutikna, T., Turney, C. S., Westaway, K. E., et al. (2004). Archaeology and age of a new hominin from Flores in eastern Indonesia. Nature 431: 1087-1091.

Murray-Wallace, C. V., and Woodroffe, C. D. (2014). Quaternary Sea-level Changes: A Global Perspective, Cambridge University Press, Cambridge.

Nakagawa, R., Doi, N., Nishioka, Y., Nunami, S., Yamauchi, H., Fujita, M., et al. (2010). Pleistocene human remains from Shiraho-Saonetabaru Cave on Ishigaki Island, Okinawa, Japan, and their radiocarbon dating. Anthropological Science 118: 173-183.

Neall, V. E., Wallace, R. C., and Torrence, R. (2008). The volcanic environment for 40,000 years of human occupation on the Willaumez Isthmus, West New Britain, Papua New Guinea. Journal of Volcanology and Geothermal Research 176: 330-343.

Norman, K., Inglis, J., Clarkson, C., Faith, J. T., Shulmeister, J., and Harris, D. (2018). An early colonisation pathway into northwest Australia 70-60,000 years ago. Quaternary Science Reviews 180: 229-239.

Norton, C. J., Kondo, Y., Ono, A., Zhang, Y. and Diab, M. C. (2010). The nature of megafaunal extinctions during the MIS 3-2 transition in Japan. Quaternary International 211: 113-122.

O'Connell, J. F., and Allen, J. (2012). The restaurant at the end of the universe: Modelling the colonisation of Sahul. Australian Archaeology 74: 5-31.

O’Connell, J. F., Allen, J., Williams, M. A., Williams, A. N., Turney, C. S., Spooner, N. A., et al. (2018). When did Homo sapiens first reach Southeast Asia and Sahul? Proceedings of the National Academy of Sciences 115: 8482-8490.

O'Connor, S. (2007). New evidence from East Timor contributes to our understanding of earliest modern human colonisation east of the Sunda Shelf. Antiquity 81: 523-535. 
O'Connor, S. (2015). Crossing the Wallace Line: The maritime skills of the earliest colonists in the Wallacean Archipelago. In Kaifu, Y., Izuho, M., Goebel, T., Sato, H., and Ono, A. (eds.), Emergence and Diversity of Modern Human Behaviour in Paleolithic Asia, Texas A\&M University Press, College Station, pp. 214-224.

O'Connor, S. Spriggs, M., and Veth, P. (2002). Excavation at Lene Hara Cave establishes occupation in East Timor at least 30,000-35,000 years ago. Antiquity 76: 45-49.

O’Connor, S., Barham, A., Spriggs, M., Veth, P., Aplin, K., and Pierre, E. S. (2010a). Cave archaeology and sampling issues in the tropics: A case study from Lene Hara cave, a 42,000 year old occupation site in East Timor, Island Southeast Asia. Australian Archaeology 71: 29-40.

O'Connor, S., Aplin, K., Pierre, E. S., and Feng, Y. (2010b). Faces of the ancestors revealed: Discovery and dating of a Pleistocene-age petroglyph in Lene Hara cave, East Timor. Antiquity 84: 649-665.

O'Connor, S., Barham, A., Aplin, K., Dobney, K., Fairbairn, A., and Richards, M. (2011a). The power of paradigms: Examining the evidential basis for Early to mid-Holocene pigs and pottery in Melanesia. Journal of Pacific Archaeology 2: 1-25.

O'Connor, S., Ono, R., and Clarkson, C. (2011b). Pelagic fishing at 42,000 years before the present and the maritime skills of modern humans. Science 334: 1117-1121.

O'Connor, S., Robertson, G., and Aplin, K. P. (2014). Are osseous artefacts a window to perishable material culture? Implications of an unusually complex bone tool from the Late Pleistocene of East Timor. Journal of Human Evolution 67: 108-119.

O'Connor, S., Louys, J., Kealy, S. and Samper Carro, S. C. (2017a). Hominin dispersal and settlement east of Huxley's Line: The role of sea level changes, island size, and subsistence behavior. Current Anthropology 58: S567-S582.

O'Connor, S. Mahirta, Carro, S. C. S., Hawkins, S., Kealy, S., Louys, J., and Wood, R. (2017b). Fishing in life and death: Pleistocene fish-hooks from a burial context on Alor Island, Indonesia. Antiquity 91: $1451-1468$.

O'Connor, S., Mahirta, Kealy, S., Boulanger, C., Maloney, T., Hawkins, S., et al. (2018). Kisar and the archaeology of small islands in the Wallacean Archipelago. The Journal of Island and Coastal Archaeology, https://doi.org/10.1080/15564894.2018.1443171.

Ono, A., Sato, H., Tsutsumi, T., and Kudo, Y. (2002). Radiocarbon dates and archaeology of the Late Pleistocene in the Japanese islands. Radiocarbon 44: 477-494.

Ono, R., Nakajima, N., Nishizawa, H., Oda, S., and Soegondho, S. (2015). Maritime migration and lithic assemblage on the Talaud Islands in northern Wallacea during the Late Pleistocene to the Early Holocene. In Kaifu, Y., Izuho, M., Goebel, T., Sato, H., and Ono, A. (eds.), Emergence and Diversity of Modern Human Behaviour in Paleolithic Asia, Texas A\&M University Press, College Station, pp. 201-213.

O’Regan, H., Bishop, L., Elton, S., Lamb, A., and Turner, A. (2006). Afro-Eurasian mammalian dispersal routes of the Late Pliocene and Early Pleistocene, and their bearing on earliest hominin movements. Courier 256: 305-314.

Osvath, M., and Karvonen, E. (2012). Spontaneous innovation for future deception in a male chimpanzee. PLOS One 7: e36782.

Osvath, M., and Osvath, H. (2008). Chimpanzee (Pan troglodytes) and orangutan (Pongo abelii) forethought: Self-control and pre-experience in the face of future tool use. Animal Cognition 11: $661-674$.

Paijmans, K. (1976). New Guinea Vegetation, Australian National University Press, Canberra.

Panagopoulou, E., Kotjaboulou, E., and Karkanas, P. (2001). Geoarchaeological research in Alonnissos: New evidence for the Palaeolithic and Mesolithic in the Aegean region. In Sampson, A. (ed.), Archaeological Investigations in the Northern Sporades, Community of Alonnisos, Alonissos, pp. $121-151$.

Papoulia, C. (2017). Seaward dispersals to the NE Mediterranean islands in the Pleistocene: The lithic evidence in retrospect. Quaternary International 431: 64-87.

Pasveer, J. (2004). The Djief Hunters: 26,000 Years of Rainforest Exploitation on the Bird's Head of Рариа, Indonesia, A. A. Balkema Publishers, Leiden.

Pavlides, C. (1999). The Story of Imlo: The Organisation of Flaked Stone Technologies from the Lowland Tropical Rainforest of West New Britain, Papua New Guinea, Ph.D. thesis, Department of Archaeology, La Trobe University, Melbourne.

Pavlides, C. (2004). From Misisil Cave to Eliva Hamlet: Rediscovering the Pleistocene in interior West New Britain. Records of the Australian Museum S29: 97-108. 
Pavlides, C., and Gosden, C. (1994). 35,000-year-old sites in the rainforests of West New Britain. Antiquity 68: 604-610.

Pawlik, A. F. (2004). The Palaeolithic site of Arubo 1 in central Luzon, Philippines. Bulletin of the IndoPacific Prehistory Association 24: 3-12.

Perry, J. (1983). Anatomy and biomechanics of the shoulder in throwing, swimming, gymnastics, and tennis. Clinical Sports Medicine 2: 247-270.

Phoca-Cosmetatou, N., and Rabett, R. (2014). Discussion and debate: Reflections on Pleistocene island occupation. Journal of Mediterranean Archaeology 27: 255-278.

Piperno, M., Scali, S., and Tagliacozzo, A. (1980). Mesolitico e Neolitico alla Grotta deli’Uzzo (Trapani): Primi dati per un'interpretazione paleoeconomica. Quaternaria 22: 275-300.

Price, T., Yeh, P. J., and Harr, B. (2008). Phenotypic plasticity and the evolution of a socially selected trait following colonization of a novel environment. The American Naturalist 172: S49-S62.

Rabett, R. J. (2017). The early human occupation of East and Southeast Asia. In Habu, J., Lape, P., and Olsen, J. (eds.), Handbook of East and Southeast Asian Archaeology, Springer, New York, pp. $159-193$.

Rabett, R. J. (2018). The success of failed Homo sapiens dispersals out of Africa and into Asia. Nature Ecology \& Evolution 2: 212-219.

Ramis, D., and Alcover, J. A. (2001). Revisiting the earliest human presence in Mallorca, western Mediterranean. Proceedings of the Prehistoric Society 67: 261-269.

Ramos, J., Bernal, D., Domínguez-Bella, S., Calado, D., Ruiz, B., Gil, M. J., et al. (2008). The Benzú rockshelter: A Middle Palaeolithic site on the North African coast. Quaternary Science Reviews 27: 2210-2218.

Reader, S. M., and Laland, K. N. (2002). Social intelligence, innovation, and enhanced brain size in primates. Proceedings of the National Academy of Sciences 99: 4436-4441.

Reepmeyer, C., O’Connor, S., Mahirta, Maloney, T., and Kealy, S. (2016). Late Pleistocene/Early Holocene maritime interaction in southeastern Indonesia - Timor Leste. Journal of Archaeological Science 76: 21-30.

Renfrew, C., and Aspinall, A. (1990). Aegean obsidian and Franchthi cave. In Perles, C. (ed.), Les industries lithiques taillées de Franchthi (Argolide, Grèce): Les industries du Mésolithique et du Néolithique initial, Excavations at Franchthi Cave 5, Indiana University Press, Bloomington, pp. 257-270.

Rizal, Y., Westaway, K. E., Zaim, Y., van den Bergh, G. D., Bettis, E. A., Morwood, M. J., et al. (2020). Last appearance of Homo erectus at Ngandong, Java, 117,000-108,000 years ago. Nature 577: $381-385$.

Robert, I., and Vigne, J.-D. (2002). The bearded vulture (Gypaetus barbatus) as an accumulator of archaeological bones: Late glacial assemblages and present-day reference data in Corsica (western Mediterranean). Journal of Archaeological Science 29: 763-777.

Roberts, P. (2015). "We have never been behaviourally modern": The implications of material engagement theory and metaplasticity for understanding the Late Pleistocene record of human behaviour. Quaternary International 30: 1-13.

Roberts, P., and Amano, N. (2019). Plastic pioneers: Hominin biogeography east of the Movius Line during the Pleistocene. Archaeological Research in Asia 17: 181-192.

Roberts, P., and Stewart, B. A. (2018). Defining the "generalist specialist" niche for Pleistocene Homo sapiens. Nature Human Behaviour 2: 542-550.

Roberts, P., Louys, J., Zech, J., Shipton, C., Kealy, S., Carro, S. S., et al. (2020). Isotopic evidence for initial coastal colonization and subsequent diversification in the human occupation of Wallacea. Nature Communications 11: 2068.

Roe, D. (1993). Prehistory without Pots: Prehistoric Settlement and Economy of North-west Gaudalcanal, Solomon Islands, Ph.D. thesis, Department of Prehistory, Australian National University, Canberra.

Rolland, N. (2013). The Early Pleistocene human dispersals in the Circum-Mediterranean Basin and initial peopling of Europe: Single or multiple pathways? Quaternary International 316: 59-72.

Runnels, C. (2014). Early Palaeolithic on the Greek islands? Journal of Mediterranean Archaeology 27: 211-230.

Runnels, C. (in press). The Paleolithic exploration of the Greek islands and Middle Pleistocene hominin dispersals: The case for behavioral variability over behavioral modernity. In Napolitano, M. (ed.), The Archaeology of Island Colonization: Global Approaches to Initial Human Settlement, University of Florida Press, Gainesville. 
Runnels, C., DiGregorio, C., Wegmann, K. W., Gallen, S. F., Strasser, T. F., and Panagopoulou, E. (2014a). Lower Palaeolithic artifacts from Plakias, Crete: Implications for hominin dispersals. Eurasian Prehistory 11: 129-152.

Runnels, C., McCoy, F., Bauslaugh, R., and Murray, P. (2014b). Palaeolithic research at Mochlos, Crete: New evidence for Pleistocene maritime activity in the Aegean. Antiquity Project Gallery 88: 342.

Ruxton, G. D., and Wilkinson, D. M. (2012). Population trajectories for accidental versus planned colonisation of islands. Journal of Human Evolution 63: 507-511.

Salotti, M., Louchart, A., Bailon, S., Lorenzo, S., Oberlin, C., Ottaviani-Spella, M.-M., Pereira, E., and Tramoni, P. (2008). A Teppa di U Lupinu Cave (Corsica, France)—Human presence since 8500 years BC, and the enigmatic origin of the earlier, Late Pleistocene accumulation. Acta Zoologica Cracoviensia - Series A: Vertebrata 51: 15-34.

Samper Carro, S.C., O’Connor, S., Louys, J., Hawkins, S., and Mahirta (2016). Human maritime subsistence strategies in the Lesser Sunda Islands during the Terminal Pleistocene-Early Holocene: New evidence from Alor, Indonesia. Quaternary International 416: 64-79.

Sathiamurthy, E., and Voris, H. K. (2006). Maps of Holocene sea level transgression and submerged lakes on the Sunda Shelf. Tropical Natural History 2: 1-44.

Sato, H. (2012). Late Pleistocene trap-pit hunting in the Japanese Archipelago. Quaternary International 248: 43-55.

Schlebusch, C. M., Malmström, H., Günther, T., Sjödin, P., Coutinho, A., Edlund, H., et al. (2017). Southern African ancient genomes estimate modern human divergence to 350,000 to 260,000 years ago. Science 358: 652-655.

Schoener, A., and Schoener, T. W. (1984). Experiments on dispersal: Short-term floatation of insular anoles, with a review of similar abilities in other terrestrial animals. Oecologia 63: 289-294.

Selimiotis, H. (2006). The Core of the Matter: Core Reduction in Prehistoric East Timor. M.A. thesis, Department of Archaeology, Australian National University, Canberra.

Sémah, F., and Sémah, A. M. (2013). Pleistocene migrations in the Southeast Asian archipelagos. In Bellwood, P. (ed.), The Global Prehistory of Human Migration, Wiley-Blackwell, Oxford, pp. 49-54.

Shaw, B. (2017). Late Pleistocene colonisation of the eastern New Guinea islands? The potential implications of robust waisted stone tool finds from Rossel Island on the long term settlement dynamics in the Massim region. Journal of Pacific Archaeology 8: 1-16.

Shea, J. J. (2011). Homo sapiens is as Homo sapiens was: Behavioral variability versus "behavioral modernity" in Paleolithic archaeology. Current Anthropology 52: 1-35.

Shen, G., Wu, X., Wang, Q., Tu, H., Feng, Y. X., and Zhao, J. X. (2013). Mass spectrometric U-series dating of Huanglong Cave in Hubei Province, central China: Evidence for early presence of modern humans in eastern Asia. Journal of Human Evolution 65: 162-167.

Shinoda, K., and Adachi, N. (2017). Ancient DNA analysis of Palaeolithic Ryukyu islanders. In Piper, P., Matsumura, H., and Bulbeck, D. (eds.), New Perspectives in Southeast Asian and Pacific Prehistory, Australian National University ePress, Canberra, pp. 51-59.

Shipton, C., Roberts, P., Archer, W., Armitage, S. J., Bita, C., Blinkhorn, J., et al. (2018). 78,000-year-old record of Middle and Later Stone Age innovation in an East African tropical forest. Nature Communications 9: 1832 .

Simmons, A. H. (1988). Extinct pygmy hippopotamus and early man in Cyprus. Nature 333: 554-557.

Simmons, A. H. (1991). Humans, island colonization and Pleistocene extinctions in the Mediterranean: The view from Akrotiri Aetokremnos, Cyprus. Antiquity 65: 857-869.

Simmons, A. H. (1999). Faunal Extinction in an Island Society: Pygmy Hippopotamus Hunters of Cyprus, Kluwer Academic Publishers, New York.

Skarpelis, N., Carter, T., Contreras, D. A., and Mihailović, D. D. (2017). Characterization of the siliceous rocks at Stélida, an early prehistoric lithic quarry (northwest Naxos, Greece), by petrography and geochemistry: A first step towards chert sourcing. Journal of Archaeological Science: Reports 12: $819-833$.

Skeates, R. (2001). New radiocarbon dates for prehistoric Italy and Malta. Accordia Research Papers 8: $165-186$.

Skeates, R. (2012). Caves in need of context: Prehistoric Sardinia. In Bergsvik, K.A., and Skeates, R. (ed.), Caves in Context: The Cultural Significance of Caves and Rockshelters in Europe, Oxbow Books, Oxford, pp. 166-187.

Smith, A., and Allen, J. (1999). Pleistocene shell technologies: Evidence from island Melanesia. In Hall, J., and McNiven, I. (eds.), Australian Coastal Archaeology, Department of Archaeology and Natural History, Australian National University, pp. 291-297. 
Sondaar, P. Y. (1989). Did man reach Australia via the giant rat and dingo route? Publication of the Geological Research and Development Center, Paleontology Series 5: 76-83.

Sondaar, P. Y., Sanges, M., Kotsakis, T., and de Boer, P. L. (1986). The Pleistocene deer hunter of Sardinia. Geobios 19: 17-31.

Specht, J., Lilley, J., and Normu, J. (1981). Radiocarbon dates from West New Britain, Papua New Guinea. Australian Archaeology 12: 13-16.

Spoor, F. (1999). The human fossils from Corbeddu Cave, Sardinia: A reappraisal. Deinsea 7: 297-302

Spriggs, M. (2001). How AMS dating changed my life. In Jones, M., and Sheppard, P. (eds.), Australasian Connections and New Directions, Department of Anthropology, University of Auckland, Auckland, pp. 365-374.

Sprintall, J., Gordon, A. L., Koch-Larrouy, A., Lee, T., Potemra, J. T., Pujiana, K., and Wijffels, S. E. (2014). The Indonesian seas and their role in the coupled ocean-climate system. Nature Geoscience 7: 487-492.

Stiner, M. C., and Kuhn, S. L. (1992). Subsistence, technology, and adaptive variation in Middle Paleolithic Italy. American Anthropologist 94: 306-339.

Storm, P. (2012). A carnivorous niche for Java Man? A preliminary consideration of the abundance of fossils in Middle Pleistocene Java. Comptes Rendus Palevol 11: 191-202.

Strasser, T. F., Panagopoulou, E., Runnels, C. N., Murray, P. M., Thompson, N., Karkanas, P., McCoy, F. W., and Wegmann, K. W. (2010). Stone Age seafaring in the Mediterranean: Evidence from the Plakias region for Lower Palaeolithic and Mesolithic habitation of Crete. Hesperia 79: 145-190.

Strasser, T. F., Runnels, C., Wegmann, K., Panagopoulou, E., Mccoy, F., Digregorio, C., Karkanas, P., and Thompson, N. (2011). Dating Palaeolithic sites in southwestern Crete, Greece. Journal of Quaternary Science 26: 553-560.

Strasser, T. F., Runnels, C., and Vita-Finzi, C. (2016). A possible Palaeolithic handaxe from Cyprus. Antiquity Project Gallery 90: 350.

Stringer, C. B., Finlayson, J. C., Barton, R. N. E., Fernández-Jalvo, Y., Cáceres, I., Sabin, R. C., et al. (2008). Neanderthal exploitation of marine mammals in Gibraltar. Proceedings of the National Academy of Sciences 105: 14319-14324.

Suchak, M., Eppley, T. M., Campbell, M. W., and de Waal, F. B. (2014). Ape duos and trios: Spontaneous cooperation with free partner choice in chimpanzees. PeerJ 2: e417.

Summerhayes, G. R. (2007). Island Melanesian pasts: A view from archaeology. In Friedlaender, J. (ed.), Genes, Language and Culture History in the Southwest Pacific, Oxford University Press, Oxford, pp. 10-35.

Summerhayes, G. R., and Allen, J. (1993). The transport of Mopir obsidian to Late Pleistocene New Ireland. Archaeology in Oceania 28: 144-148.

Summerhayes, G. R., and Ford, A. (2014). Late Pleistocene colonisation and adaptation in New Guinea: Implications for modeling modern human behaviour. In Dennell, R., and Porr, M. (eds.), Southern Asia, Australia and the Search for Human Origins, Cambridge University Press, Cambridge, pp. 213-227.

Summerhayes, G. R., Leavesley, M., Fairbairn, A., Mandui, H., Field, J., Ford, A., and Fullagar, R. (2010). Human adaptation and use of plants in highland New Guinea 49,000-44,000 years ago. Science 330: 78-81.

Summerhayes, G. R., Field, J. H., Shaw, B., and Gaffney, D. (2017). The archaeology of forest exploitation and change in the tropics during the Pleistocene: The case of northern Sahul (Pleistocene New Guinea). Quaternary International 448: 14-30.

Sutikna, T., Tocheri, M. W., Morwood, M. J., Saptomo, E. W., Jatmiko, Awe, R. D., et al. (2016). Revised stratigraphy and chronology for Homo floresiensis at Liang Bua in Indonesia. Nature 532: 366.

Sutikna, T., Tocheri, M. W., Faith, J. T., Awe, R. D., Meijer, H. J., Saptomo, E. W., and Roberts, R. G. (2018). The spatio-temporal distribution of archaeological and faunal finds at Liang Bua (Flores, Indonesia) in light of the revised chronology for Homo floresiensis. Journal of Human Evolution 124: 52-74.

Suzuki, H., and Hanihara, K. (eds.) (1982). The Minatogawa Man: The Upper Pleistocene Man from the Island of Okinawa, University of Tokyo Press, Tokyo.

Swadling, P., and Hope, G. (1992). Environmental change in New Guinea since human settlement. In Dodson, J. (ed.), The Naive Lands: Prehistory and Environmental Change in Australia and the Southwest Pacific, Longmans Cheshire, Melbourne, pp. 13-42.

Szabó, K., Brumm, A., and Bellwood, P. (2007). Shell artefact production at 32,000-28,000 BP in Island Southeast Asia: Thinking across media? Current Anthropology 48: 701-723. 
Takahara, H., and Hayashi, R. (2015). Paleovegetation during Marine Isotope Stage 3 in East Asia. In Kaifu, Y., Izuho, M., Goebel, T., Sato, H., and Ono, A. (eds.), Emergence and Diversity of Modern Human Behaviour in Paleolithic Asia, Texas A\&M University Press, College Station, pp. 314-324.

Takamiya, H., Katagiri, C., Yamasaki, S., and Fujita, M. (in press). Human colonization of the central Ryukyus (Amami and Okinawa archipelagos), Japan. The Journal of Island and Coastal Archaeology.

Takashi, T. (2012). MIS3 edge-ground axes and the arrival of the first Homo sapiens in the Japanese Archipelago. Quaternary International 248: 70-78.

Tanudirjo, D. A. (2001). Islands in Between: Prehistory of the Northeastern Indonesian Archipelago, Ph.D. thesis, School of Archaeology and Anthropology, Australian National University, Canberra.

Texier, P. J., Porraz, G., Parkington, J., Rigaud, J. P., Poggenpoel, C., Miller, C., et al. (2010). A Howiesons Poort tradition of engraving ostrich eggshell containers dated to 60,000 years ago at Diepkloof rock shelter, South Africa. Proceedings of the National Academy of Sciences 107: 6180-6185.

Thieme, H. (2005). The Lower Palaeolithic art of hunting: The case of Schöningen 13 II-4, Lower Saxony, Germany. In Gamble, C., and Porr, M. (eds.), The Hominid Individual in Context: Archaeological Investigations of Lower and Middle Palaeolithic Landscapes, Locales and Artefacts, Routledge, London, pp. 115-132.

Tiauzon, A., Peterson, J., Robles, E. C., Neri, L. A., Forestier, H., Titton, S., et al. (in press). Unfolding the technological production strategies of the large toolkits across Philippine Paleolithic sites with specific reference to northern Mindanao. Quaternary International https://oi. org/10.1016/j.quaint.2018.10.037.

Timmermann, A., and Friedrich, T. (2016). Late Pleistocene climate drivers of early human migration. Nature 538: 92-95.

Torrence, R. (2004). Now you see it, now you don't: Changing obsidian source use in the Willaumez Peninsula, Papua New Guinea. In Cherry, J., Scarre, C., and Shennan, S. (eds.), Explaining Social Change: Studies in Honour of Colin Renfrew, McDonald Institute of Archaeolgoical Research, Cambridge, pp. 115-125.

Torrence, R. (2005). Valued stone-How so. In Macfarlane, I., Mountain, M.-J., and Paton, R. (eds.), Many Exchanges: Archaeology, History, Community and the Work of Isabel McBryde, Aboriginal History Inc., Canberra, pp. 357-372.

Torrence, R. (2012). Boats, stones, and risk: Response to O'Connell and Allen. Australian Archaeology 74: 26-27.

Torrence, R. (2016). Social resilience and long-term adaptation to volcanic disasters: The archaeology of continuity and innovation in the Willaumez Peninsula, Papua New Guinea. Quaternary international 394: 6-16.

Torrence, R., Neall, V., Doelman, T., Rhodes, E., McKee, C., Davies, H., et al. (2004). Pleistocene colonisation of the Bismarck Archipelago: New evidence from West New Britain. Archaeology in Oceania 39: 101-130.

Tourloukis, V., and Karkanas, P. (2012). The Middle Pleistocene archaeological record of Greece and the role of the Aegean in hominin dispersals: New data and interpretations. Quaternary Science Reviews 43: 1-15.

Tsutsumi, T. (2010). Prehistoric procurement of obsidian from sources on Honshu Island (Japan). In Kuzmin, Y. V., and Glascock, M. D. (eds.), Crossing the Straits: Prehistoric Obsidian Source Exploitation in the North Pacific Rim, Archaeopress, Oxford, pp. 27-55.

Turvey, S. T., Crees, J. J., Hansford, J., Jeffree, T. E., Crumpton, N., Kurniawan, I., et al. (2017). Quaternary vertebrate faunas from Sumba, Indonesia: Implications for Wallacean biogeography and evolution. Proceedings of the Royal Society B 284: 20171278.

Vacca, B. B. (2012). The hunting of large mammals in the Upper Palaeolithic of southern Italy: A diachronic case study from Grotta del Romito. Quaternary International 252: 155-164.

van den Bergh, G. D., de Vos, J., and Sondaar, P. Y. (2001). The Late Quaternary palaeogeography of mammal evolution in the Indonesian Archipelago. Palaeogeography, Palaeoclimatology, Palaeoecology 171: 385-408.

van den Bergh, G. D, Kaifu, Y., Kurniawan, I., Kono, R. T., Brumm, A., Setiyabudi, E., Aziz, F., and Morwood, M. J. (2016a). Homo floresiensis-like fossils from the early Middle Pleistocene of Flores. Nature 534: 245-248.

van den Bergh, G. D., Li, B., Brumm, A., Grün, R., Yurnaldi, D., Moore, M. W., et al. (2016b). Earliest hominin occupation of Sulawesi, Indonesia. Nature 529: 208-211. 
van der Geer, A. A. E., van den Bergh, G. D., Lyras, G. A., Prasetyo, U. W., Due, R. A., Setiyabudi, E., and Drinia, H. (2016). The effect of area and isolation on insular dwarf proboscideans. Journal of Biogeography 43: 1656-1666.

Vanhaeren, M., d'Errico, F., Stringer, C., James, S. L., Todd, J. A., and Mienis, H. K. (2006). Middle Paleolithic shell beads in Israel and Algeria. Science 312: 1785-1788.

Vannieuwenhuyse, D. (2016). Mind the Gap: Geoarchaeology and Micromorphology of Cave and Rockshelter Sequences from the Kimberley, North-west Australia, Ph.D. thesis, School of Social Science, University of Western Australia, Crawley.

Veth, P. (2005). Between the desert and the sea: Archaeologies of the Western Desert and Pilbara regions, Australia. In Smith, M. A., and Hesse, P. (eds.), $23^{\circ} \mathrm{S}$ : Archaeology and Environmental History of the Southern Deserts, National Museum of Australia, Canberra, pp.132-141.

Vigliardi, A. (1982). Gli strati paleo-mesolitici della Grotta di Levanzo. Rivista di Scienze Preistoriche 37: 3-58.

Vigne, J. D., Zazzo, A., Saliège, J. F., Poplin, F., Guilaine, J. and Simmons, A. (2009). Pre-Neolithic wild boar management and introduction to Cyprus more than 11,400 years ago. Proceedings of the National Academy of Sciences 106: 16135-16138.

Voris, H. K. (2000). Maps of Pleistocene sea levels in Southeast Asia: Shorelines, river systems and time durations. Journal of Biogeography 27: 1153-1167.

Walter, R. C., Buffler, R. T., Bruggemann, J. H., Guillaume, M. M. M., Berhe, S. M., Negassi, B., et al. (2000). Early human occupation of the Red Sea coast of Eritrea during the last interglacial. Nature 405: 65-69.

Watts, I., Chazan, M., and Wilkins, J. (2016). Early evidence for brilliant ritualized display: Specularite use in the Northern Cape (South Africa) between 500 and 300 Ka. Current Anthropology 57: $287-310$.

Watts, J., Fulfrost, B., and Erlandson, J. (2011). Searching for Santarosae: Surveying submerged landscapes for evidence of Paleocoastal habitation off California's northern Channel Islands. In Ford, B. L. (ed.), The Archaeology of Maritime Landscapes, Springer, New York, pp. 11-26.

Webb, J. K., Letnic, M., Jessop, T. S., and Dempster, T. (2014). Behavioural flexibility allows an invasive vertebrate to survive in a semi-arid environment. Biology Letters 10: 20131014.

West-Eberhard, M. J. (2003). Developmental Plasticity and Evolution, Oxford University Press, Oxford.

Westaway, K. E., Morwood, M. J., Roberts, R. G., Rokus, A. D., Zhao, J. X., Storm, P., et al. (2007). Age and biostratigraphic significance of the Punung rainforest fauna, East Java, Indonesia, and implications for Pongo and Homo. Journal of Human Evolution 53: 709-717.

Westaway, K. E., Louys, J., Awe, R. D., Morwood, M. J., Price, G. J., Zhao, J. X., et al. (2017). An early modern human presence in Sumatra 73,000-63,000 years ago. Nature 548: 322-325.

White, J. P., and Thomas, D. H. (1972). What mean these stones? Ethnotaxonomic models and archaeological interpretations in the New Guinea Highlands. In Clarke, D. (ed.), Models in Archaeology, Methuen, London, pp. 275-308.

White, J. P., Flannery, T. F., O’Brien, R., Hancock, R. V., and Pavlish, L. (1991). The Balof shelters, New Ireland. In Allen, J., and Gosden, C. (eds.), Report of the Lapita Homeland Project, Department of Prehistory, Australian National University, Canberra, pp. 46-58.

Wickler, S. (2001). The Prehistory of Buka: A Stepping Stone Island in the Northern Solomons, Terra Australis 16, Department of Archaeology and Natural History, Australian National University, Canberra.

Wickler, S., and Spriggs, M. (1988). Pleistocene human occupation of the Solomon Islands, Melanesia. Antiquity 62: 703-706.

Wilkins, J., and Chazan, M. (2012). Blade production 500 thousand years ago at Kathu Pan 1, South Africa: Support for a multiple origins hypothesis for early Middle Pleistocene blade technologies. Journal of Archaeological Science 39: 1883-1900.

Will, M., Kandel, A. W., and Conard, N. J. (2019). Midden or molehill: The role of coastal adaptations in human evolution and dispersal. Journal of World Prehistory 32: 33-72.

Wilmshurst, J. M., Hunt, T. L., Lipo, C. P., and Anderson, A. J. (2011). High-precision radiocarbon dating shows recent and rapid initial human colonization of East Polynesia. Proceedings of the National Academy of Sciences 108: 1815-1820.

Wright, T. F., Eberhard, J. R., Hobson, E. A., Avery, M. L., and Russello, M. A. (2010). Behavioral flexibility and species invasions: The adaptive flexibility hypothesis. Ethology Ecology \& Evolution 22: 393-404. 
Wynn, T. (1993). Two developments in the mind of early Homo. Journal of Anthropological Archaeology 12: 299-322.

Xhauflair, H., and Pawlik, A. (2010). Usewear and residue analysis: Contribution to the study of the lithic industry from Tabon Cave, Palawan, Philippines. Sezione di Museologia Scientifica e Naturalistica 6: $147-154$.

Xhauflair, H., Pawlik, A., Gaillard, C., Forestier, H., Vitales, T. J., Callado, J. R., et al. (2016). Characterisation of the use-wear resulting from bamboo working and its importance to address the hypothesis of the existence of a bamboo industry in prehistoric Southeast Asia. Quaternary International 416: 95-125.

Xhauflair, H., Revel, N., Vitales, T. J., Callado, J. R., Tandang, D., Gaillard, C., et al. (2017). What plants might potentially have been used in the forests of prehistoric Southeast Asia? An insight from the resources used nowadays by local communities in the forested highlands of Palawan Island. Quaternary International 448: 169-189.

Zazzo, A., Lebon, M., Quiles, A., Reiche, I. and Vigne, J. D. (2015). Direct dating and physico-chemical analyses cast doubts on the coexistence of humans and dwarf hippos in Cyprus. PLOS ONE 10: p.e0134429.

Zong, C. (2015). Late Pleistocene Sea Levels and Resulting Changes in Global Land Distributions, Ph.D. dissertation, Department of Geography, University of Kansas, Lawrence.

\section{Bibliography of Recent Literature}

Anderson, A., and Boyle, K. V. (eds.) (2010). The Global Origins and Development of Seafaring, McDonald Institute for Archaeological Research, Cambridge.

Bellwood, P. (ed.) (2019). The Spice Islands in Prehistory: Archaeology in the Northern Moluccas, Indonesia, Terra Australis 50, Australian National University Press, Canberra.

Dawson, H. (2013). Mediterranean Voyages: The Archaeology of Island Colonisation and Abandonment, Left Coast Press, Walnut Creek, CA.

Dennell, R., and Porr, M. (eds.) (2014). Southern Asia, Australia, and the Search for Human Origins, Cambridge University Press, Cambridge.

Fagan, B. (2012). Beyond the Blue Horizon: How the Earliest Mariners Unlocked the Secrets of the Oceans, Bloomsbury Publishing, London.

Kaifu, Y., Izuho, M., Goebel, T., Sato, H., and Ono, A. (eds.) (2015). Emergence and Diversity of Modern Human Behavior in Paleolithic Asia, Texas A\&M University Press, College Station.

Knapp, A. B. (2013). The Archaeology of Cyprus, Cambridge University Press, Cambridge.

O'Connor, S., Bulbeck, D., and Meyer, J. (eds.) (2018). The Archaeology of Sulawesi: Current Research on the Pleistocene to the Historic Period, Terra Australis 48, Australian National University Press, Canberra.

Pearson, R. J. (2013). Ancient Ryukyu, University of Hawaii Press, Honolulu.

Phoca-Cosmetatou, N. (ed.) (2011). The First Mediterranean Islanders: Initial Occupation and Survival Strategies, Oxbow Books, Oxford.

Pydyn, A. (2015). Argonauts of the Stone Age: Early Maritime Activity from the First Migrations from Africa to the End of the Neolithic, Archaeopress, Oxford.

Simmons, A. H. (2014). Stone Age Sailors: Paleolithic Seafaring in the Mediterranean, Routledge, London.

Walter, R., and Sheppard, P. (2017). Archaeology of the Solomon Islands, University of Otago Press, Dunedin.

Webb, S. G. (2006). The First Boat People, Cambridge University Press, Cambridge.

Publisher's Note Springer Nature remains neutral with regard to jurisdictional claims in published maps and institutional affiliations. 